\title{
La discrecionalidad del juez penal y \\ Reseña crítica del sistema penal acusatorio en Colombia
}

\section{German Alonso Castañeda Torres}

\author{
UNIVERSIDAD SANTO TOMAS \\ FACULTAD DE DERECHO \\ MAESTRÍA EN DERECHO PENAL
}

Bogotá D.C

2016 


\title{
La discrecionalidad del juez penal y \\ Reseña crítica del sistema penal acusatorio en Colombia
}

\author{
German Alonso Castañeda Torres
}

Trabajo de investigación para optar al título de

Magister en Derecho Penal

Director

Dr. Alejandro Gómez Jaramillo

UNIVERSIDAD SANTO TOMAS

FACULTAD DE DERECHO

MAESTRÍA EN DERECHO PENAL

Bogotá D.C

2016 


\section{NOTA DE ACEPTACIÓN}

DOCTOR JULIO MONTAÑEZ

PRESIDENTE DEL JURADO

DOCTOR DIEGO CORREDOR

JURADO

DOCTOR JAIME SANDOVAL

JURADO

Bogotá D.C. Junio de 2016 
A mis padres... que permanecerán en mi recuerdo siempre.

A mi esposa Constanza y a mis hijas Anabel y Alejandra, quienes me brindaron su apoyo y comprensión durante la elaboración de este trabajo de tesis.

A los jueces y funcionarios judiciales, para que asuman sus decisiones en el marco correcto de la discrecionalidad, sin ningún temor... éste es el camino de la justicia. 


\section{Agradecimientos}

Agradezco a Dios por darme salud y lucidez para culminar este proceso.

Al Dr. Alejandro Gómez Jaramillo, director de tesis, por su sabia orientación.

Al Dr. Carlos Castro Gómez, colega y amigo, por sus valiosas ideas.

Y a quienes de una u otra forma realizaron críticas valiosas que hicieron posible esta investigación. 


\section{Contenido}

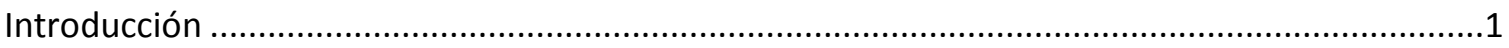

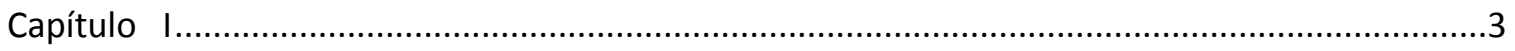

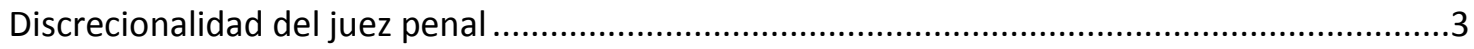

Doctrinas negadoras de la existencia de discrecionalidad judicial .......................................

Escuela de la Exégesis y Jurisprudencia de Conceptos..........................................................

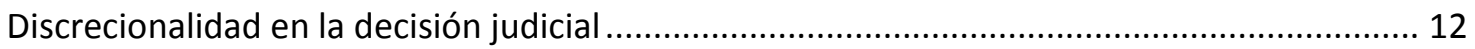

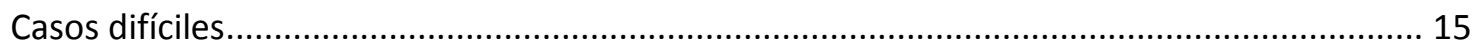

Teorías de la interpretación de la ley, fines y consecuencias .............................................. 16

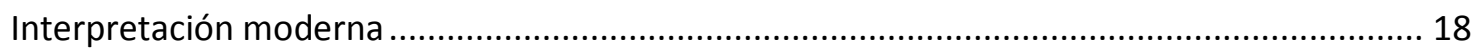

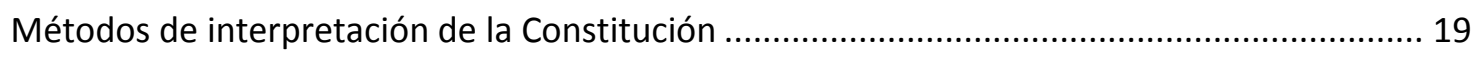

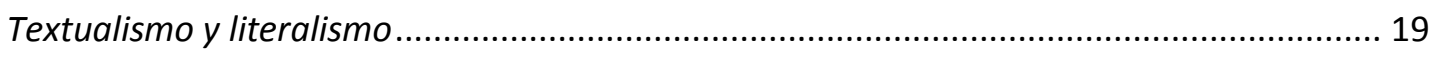

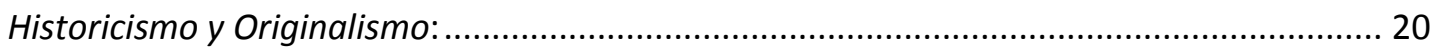

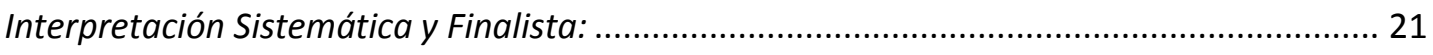

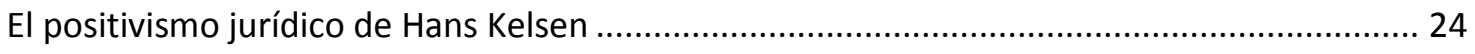

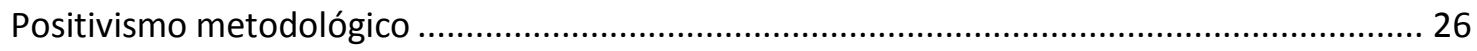

Doctrinas y planteamientos de Dworkin y el Neoconstitucionalismo. ................................... 27

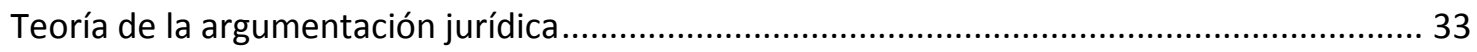

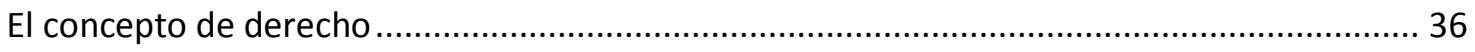

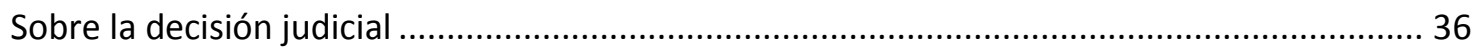

Criticas del derecho a la Teoría de la Adjudicación Judicial ................................................. 43

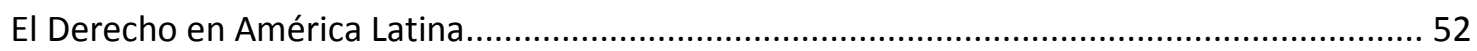

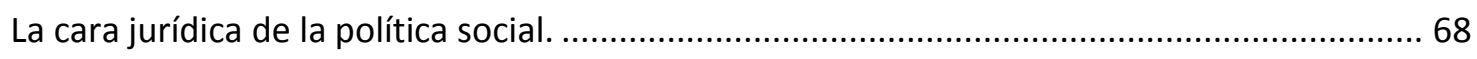

Derechos sociales e instrumentos internacionales de derechos humanos ............................. 68 


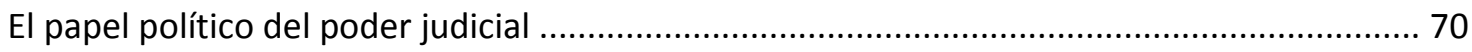

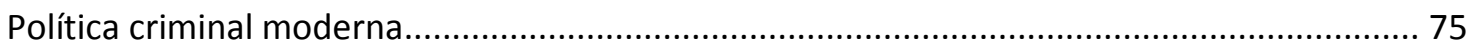

Problemática del antecedente y del precedente judicial en Colombia .................................... 86

Capitulo II: Problemática del sistema penal acusatorio colombiano. Ley 906 de 2004................ 91

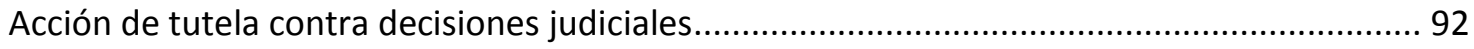

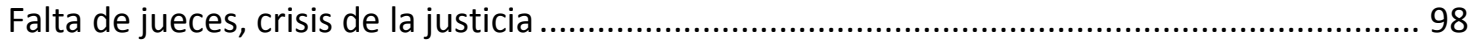

Control formal y material de la formulación de imputación y de la formulación de la acusación

Problemática actual con los preacuerdos y negociaciones: los allanamientos producen penas

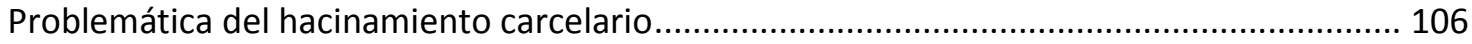

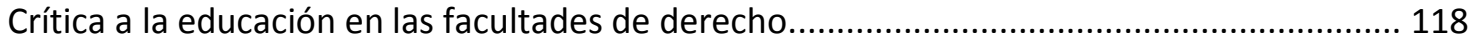

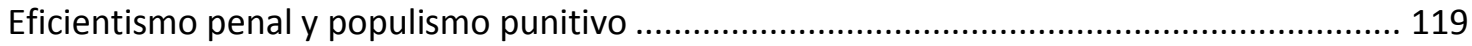

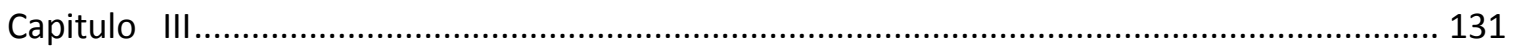

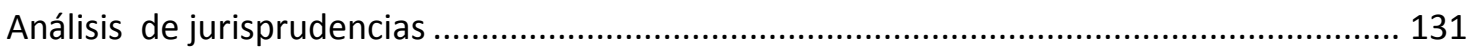

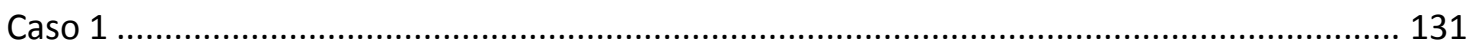

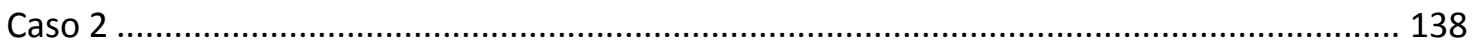

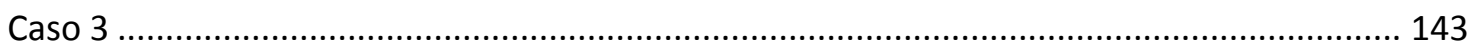

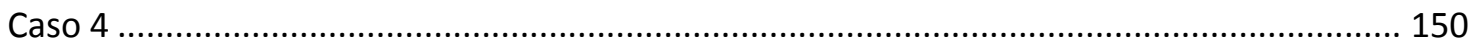

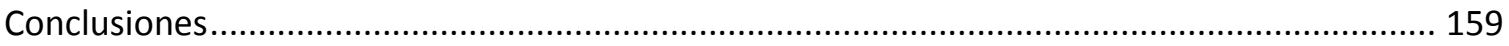

Anexo 1: Respuesta Derecho de Petición de Información EXPSA14-4789.................................. 163

Anexo 2: Respuesta a solicitud de información sobre despachos del SPA ................................ 164

Anexo 3: Derecho de Petición de Información EXPSA14-4789 …............................................. 168

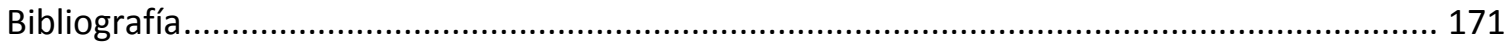




\section{Introducción}

Los capítulos en esta investigación, recogen una serie de estudios críticos del derecho con base en los cuales, se pretende dar bases sólidas y científicas al planteamiento de una situación frecuente en el desarrollo de la práctica jurídica, que nos ha preocupado a lo largo de varios años de ejercer el derecho y que podemos plantear de la siguiente manera: la tendencia a centrarse en las normas positivas, la atención marginal a la jurisprudencia y el escaso análisis de las relaciones entre el derecho y la vida social, impiden que un juez sea neutral en sus decisiones.

El primer capítulo de esta investigación trata de diversas doctrinas sobre la discrecionalidad del juez, sustentada en varios estudios críticos del derecho, que nacen en los años 70 en Estados Unidos, como herederos del realismo norteamericano de la primera mitad del siglo XX, especialmente los del jurista estadounidense Duncan Kennedy y Robert Alexy, entre otros. La tesis principal de Kennedy es que "el juez en la adjudicación judicial busca reproducir un deseo: el deseo de llegar a una sentencia políticamente favorable a sus convicciones, con relativa independencia del campo jurídico que se estudia”. También se tratará aquí, sobre la libertad y la restricción en la decisión judicial y las teorías jurídicas dominantes en Colombia, entre otros temas. Es decir, se hará un análisis científico de la práctica del juez penal.

En el segundo capítulo y basándonos en estudios y estadísticas realizadas en nuestro país, se hará una crítica al sistema penal acusatorio colombiano, en cuanto a la situación carcelaria y las falencias en los procedimientos del sistema penal acusatorio colombiano actual, en sus distintas etapas y se profundizará la problemática del 
antecedente y el precedente judicial en Colombia. Esto implica, en general, hacer un diagnóstico de dicho sistema.

A continuación, en el tercer capítulo, se hará un análisis de jurisprudencias sobre casos que ilustran y corroboran lo dicho en precedencia, utilizando la metodología sociojurídica. Se desarrollarán cuatro casos con hechos similares y cuya decisión judicial ha sido diferente en cada uno de ellos.

Finalmente se expondrán las conclusiones y se hará una serie de consideraciones que incluyen las reflexiones a las que nos ha llevado esta investigación y las propuestas surgidas, como aporte al sistema judicial implementado en Colombia.

Para terminar, una afirmación del profesor Diego López Medina en una de sus notas editoriales en las que afirmó: “...los juristas sofisticados conocen, desde la insistencia en las realidades sociológicas, psicológicas y partidistas que hicieron marxistas, realistas, feministas y críticos, que el derecho no está tan lleno de imparcialidad como pregona y que puede constituirse en un arma más en la división y dominación faccional e interesada de una sociedad..." (El Derecho de los jueces, 2009) 


\section{Capítulo I}

\section{Discrecionalidad del juez penal}

Si bien es cierto que en virtud del artículo 228 de nuestra carta Política, los jueces son autónomos e independientes al momento de proferir sus decisiones judiciales, esa independencia no es absoluta, pues la misma norma constitucional en el artículo 230 le fija unos límites al establecer que los jueces en sus decisiones sólo están sometidos al imperio de la Ley; asimismo La equidad, la jurisprudencia, los principios generales del derecho y la doctrina son criterios auxiliares de la actividad judicial.

Con el advenimiento de la constitución de 1991, en virtud del artículo 241 superior la honorable corte Constitucional como encargada de velar por la guarda y supremacía de la constitución ha dicho que sus fallos de constitucionalidad, son de efectos erga omnes y son de obligatorio cumplimiento para los operadores judiciales; es decir que los pronunciamientos de la Corte, crean derecho y no son sólo criterio auxiliar como el mismo mandato superior lo establece.

Así las cosas, no sólo por mandato constitucional, sino también por la evolución doctrinaria y jurisprudencial que han sobrevenido con posterioridad a la Revolución Francesa y al constituyente del 91, que trajo consigo interesantes planteamientos como los que a continuación relaciono, nos llevan a concluir que la discrecionalidad del Juez al momento de tomar las decisiones, si no se tiene un conocimiento claro y preciso de estas corrientes y línea jurisprudencial de interpretación en la aplicación de la Ley, lleva a que el Juez confunda su autonomía e independencia con la arbitrariedad. 


\begin{abstract}
Desarrollaremos éste tema, a partir de dos interrogantes: ¿existe discrecionalidad en la decisión del juez penal? y ¿Qué significa aquí discrecionalidad?
\end{abstract}

Con este término nos referimos a la libertad de que el juez disfruta a la hora de dar contenido a su decisión de casos sin vulnerar el Derecho. Por tanto, cuando afirmamos que tal discrecionalidad existe en algún grado, queremos decir que el propio Derecho le deja al juez márgenes para que éste elija entre distintas soluciones o entre diferentes alcances de una solución del caso.

Así pues, si hay discrecionalidad significa que al juez las soluciones de los asuntos que decide no le vienen dadas y predeterminadas enteramente, al cien por ciento, por el sistema jurídico; sino que éste, en mayor o menor medida, le deja espacios para que escoja entre alternativas diversas, pero compatibles todas ellas con el sistema jurídico; por ejemplo, cuando le ordena la norma: "la duda que se presente se resolverá a favor del procesado" (Código de Procedimiento Penal, 2004. Inciso $2^{\circ}$, Art. $7^{\circ}$ )

Ha ido quedando claro que la libertad que los jueces pueden usar en su labor tiene dos manifestaciones, una positiva y admisible; la otra negativa y rechazable. La primera recibe el nombre de discrecionalidad y, repetimos, alude a aquella medida de libertad decisoria del juez que resulta inevitable e ineliminable de su cometido, por causa de los caracteres mismos que posee la materia prima de las normas, el lenguaje ordinario. La segunda, que se debe combatir, se denomina arbitrariedad. 
Una decisión judicial es arbitraria cuando el juez decide libremente, sí, pero concurriendo todas o alguna(s) de las siguientes notas:

- Vulnera las pautas decisorias que el sistema jurídico le fija para el caso, en lo que dichas pautas tengan de claras y terminantes.

- Se demuestra que lo que guía la elección del juez son móviles incompatibles con el sistema jurídico que aplica y con su función dentro de él, como interés personal, afán de medro, propósito de notoriedad, venalidad, miedo, prejuicios sociales o ideológicos, etc.

- Cuando el juez no da razón ninguna de su fallo o cuando su motivación del mismo contiene razones puramente inadmisibles, ya sean por absurdas, antijurídicas o incompatibles con los requerimientos funcionales del sistema jurídico; es decir según su personal sentido de la justicia.

\section{Doctrinas y Teorías de la discrecionalidad}

Es de gran importancia, exponer aquí las bases filosóficas y teóricas de la discrecionalidad judicial de los últimos siglos en el desarrollo del derecho positivo. Se analiza la evolución de criterios en la discrecionalidad, sea ésta basada o no en la tendencia legislativa; también se analizan los hechos derivados de la prueba y la jurisprudencia para la decisión del juez. Aspectos estos, entre otros, que inciden en la motivación y razón de un fallo.

Así mismo, al analizar las teorías de la interpretación de la ley, la hermenéutica jurídica, la interpretación en el derecho constitucional, sus corrientes y escuelas contemporáneas, se hace necesario citar varios autores como Hans Kelsen y su positivismo jurídico, García 
Amado y su teoría formal respecto de la discrecionalidad y la idealización de los franceses sobre el derecho positivo. Citaremos a Herbert L. Hart y su pensamiento de la filosofía anglosajona, Dworkin y su teoría y finalmente Robertt Alexy y su estudio de la interpretación de los derechos constitucionales, así como las escuelas que ilustran esta investigación.

\section{Doctrinas negadoras de la existencia de discrecionalidad judicial}

"Las doctrinas que combaten la discrecionalidad judicial lo hacen por dos razones entrelazadas: por un lado, por la convicción de que la discrecionalidad judicial no es conveniente; por otro lado, por la creencia de que la discrecionalidad judicial es evitable" (García Amado, 2006, 153)

Si bien, por lo que se pretende dentro de un sistema penal acusatorio, tal como lo señala la doctrina de la discrecionalidad en las decisiones, es llegar a decisiones que se convierten en objetivas, lo cual debería ser lo ideal de cualquier sistema jurídico, no lo es menos que los sistemas jurídicos se ejecutan a través de personas, que si bien parten de conocimientos jurídicos, de igual modo hacen uso de conocimientos empíricos razonables, lógicos y experiencias propias; por más que trate de demitificarse la discrecionalidad en una decisión judicial, la misma lleva intrínsecos conceptos como los antes enunciados.

Nótese cómo en el mismo enunciado el autor parte de un concepto subjetivo, como es la palabra creencia, que dentro del sistema y decisión jurídica, no tiene operatividad. 
La doctrina negadora de la discrecionalidad que plantea García Amado, resulta valida desde su análisis, ante la interpretación de la ley frente a la interpretación que se le de a la norma constitucional, pues el legislador, en la creación de normas procesales penales, debería ser un buen creador de estas, que contengan la interpretación legislativa acorde al modo de un sistema penal acusatorio, como al modelo de Estado, lo cual evitaría acudir a la interpretación jurisprudencial o mmuchas veces acudir a la norma constitucional, pues en el derecho penal ciertos valores son difícil adecuarlos a la realidad del contenido constitucional, encontrando así, en una realidad penal procesal o sustancial, diferente a la guardia constitucional.

\section{Escuela de la Exégesis y Jurisprudencia de Conceptos}

“...Esa negación de la discrecionalidad judicial aconteció en la doctrina dominante durante prácticamente todo el siglo XIX, de la mano principalmente de la Escuela de la Exégesis, en Francia, y de la Jurisprudencia de Conceptos, en Alemania..." (García Amado, 2006, 153).

“...Estas dos escuelas tenían en común su carácter ingenuamente formalista en materia de decisión judicial. Sostenían ambas que la decisión del juez tenía un carácter puramente formal, ya que consistía en un simple silogismo a partir de premisas que al juez le venían perfectamente dadas y acabadas..." (García Amado, 2006, 153).

“...La premisa mayor o normativa se la proporcionaba al juez con plena claridad y coherencia el sistema jurídico, de modo que el juez no tenía ni que inventarla ni que completarla ni que interpretarla..." (García Amado, 2006, 153). 
“...En cuanto a la premisa menor del silogismo judicial, estaría constituida por los hechos del caso, y también éstos se le ofrecen al juez con total independencia de cualquier juicio suyo. Los hechos están ahí y su prueba es un proceso objetivo en el que no queda margen para la evaluación personal del juzgador; las cosas son o no son, y son o no con independencia de las opiniones del juez. El juez, por tanto, juzga de los hechos que son, no de los que a él le parecen o de cómo a él le parecen..." (García Amado, 2006, 153).

“...En resumen, según estas dos doctrinas hay para cada caso una única solución correcta, que está presente en el Derecho mismo y que el juez puede y debe encontrar en él. La diferencia es que los franceses idealizaban el derecho positivo, su Código, mientras que los alemanes si positivizaban por vía doctrinal un derecho ideal, es decir, un derecho compuesto por esencias, no por mandatos de ningún legislador. Pero unos y otros recelaban de los jueces, rechazaban toda discrecionalidad de los mismos y los veían como puros aplicadores objetivos de reglas que encuentran y en las que de ninguna manera influyen..." (García Amado, 2006, 154).

Pero también en el pensamiento jurídico parece que rige la ley del péndulo o el mito del eterno retorno, y el formalismo decimonónico, en lo que tenía de afirmador de la perfección del sistema jurídico y de negador de la discrecionalidad judicial, ha regresado con plena pujanza a fines del siglo XX y domina hoy, en pleno siglo XXI, esta vez de la mano de doctrinas que denominaré aquí Axiologismo Jurídico y que están bien representadas por autores como Dworkin y por los representantes más radicales de esa 
doctrina que se viene denominando neoconstitucionalismo y que podría ejemplificarse en autores como el Zagrebelsky de El Derecho dúctil.

“...En los Estados de Derecho contemporáneos se ha acentuado la tendencia legislativa a la implementación de lo que se suele denominar "sistema de la libre convicción o sana crítica racional" en la valoración de la prueba. En este sistema, el control racional tendiente a eliminar la discrecionalidad judicial en esta tarea, está dado (a) por las normas que regulan el ingreso de información al proceso; y (b) por la exigencia de que dicha información se valore mediante las "reglas de la sana crítica" ..."(Bonorino \& Peña, 2006: 127).

De acuerdo con la legislación procesal, se establece que los medios de prueba - fundamento de la decisión judicial -, los EMP, la EF y la ILO, se apreciarán en su conjunto; en similar sentido la honorable Corte Suprema de Justicia en reiterada y pacífica jurisprudencia ha venido señalando que las pruebas deben ser analizadas y valoradas en su conjunto de acuerdo con la Sana Crítica (Leyes de la Lógica, máximas de la experiencia y los métodos de la ciencia), lo que no dijo el legislador; tampoco se ha desarrollado jurisprudencialmente es a cuáles leyes de la lógica se refiere, lo cual le da un amplio margen de discrecionalidad al juez penal que raya con la arbitrariedad cuando dichas reglas se ignoran o no se aplican adecuadamente.

Esta forma de resolver la cuestión es poco satisfactoria, porque la noción que se ofrece como explicación es tan oscura e imprecisa como la que se trataba de elucidar con ella, lo único que se logra es trasladar el centro de la cuestión de las "reglas de la sana 
crítica" a las "reglas del recto entendimiento humano", pero este cambio de expresiones deja intacto el problema de fondo.

Se puede sostener que dichas reglas son tan evidentes o conocidas por todos que basta con su enunciación, pero lo cierto es que la misma formulación de la explicación entraña ciertas confusiones, una de las más graves es la de colocar a las leyes de la lógica en el mismo plano que las leyes de la psicología y la experiencia, lo que hace presuponer, con acierto, que la doctrina procesal se está manejando a partir de una concepción de la lógica que ya fue abandonada hace más de un siglo.

“...Pero lo más importante es que, de esta manera, al mismo tiempo que se sostiene la necesidad de controlar racionalmente los actos de administración de justicia, se está encubriendo con este tipo de explicaciones teóricas la mayor discrecionalidad judicial imaginable respecto a la determinación de los hechos materia de enjuiciamiento...” (Bonorino \& Peña, 2006: 128)

En cuanto a este acápite, que pewse a tornarse un poco vago, comparto la escencia del planteamiento, en el entendido que muchas son las normas que existen en el ámbito jurídico que han sido enunciadas por el legislador a fin de dar una cortapisa a la discrecionalidad judicial, pero que analizadas dichas normas desde su orígen y fines de emisión, resultan ser más discrecionales que las decisiones que se prtende dar en su finalidad.

Ello de la mano con la tesis que la honorable Corte Suprema de Justicia en reiterada jurisprudencia ha venido sosteniendo en relación con la autonomía e independencia judicial, dándoles pleno respaldo a las decisiones o fallos expedidos por 
los jueces de la República, que al ser acusados por el delito de prevaricato por acción, ha dicho esta Corporación que para su materialización, se requiere contar con una resolución, dictamen o concepto ostensiblemente contrario a la legislación, es decir, que su contenido torna notorio, sin mayor dificultad, la ausencia de fundamento fáctico y jurídico, y su contradicción con la normatividad, rompiendo abruptamente la sujeción que en virtud del "imperio de la ley" del artículo 230 de la Carta Política deben los funcionarios judiciales al texto de la misma ${ }^{1}$. (Constitución Política de Colombia, 1991)

\footnotetext{
${ }^{1}$ Sentencia de 19 de febrero de 2009, de manera puntual se precisó:

De otro modo dicho, una decisión es "manifiestamente contraria a la ley"-de antaño lo ha precisado la jurisprudencia de la Sala- cuando "la contradicción entre lo demandado por la ley y lo resuelto sea notoria, grosera o de tal grado ostensible que se muestre de bulto con la sola comparación de la norma que debía aplicarse.
}

No basta pues, la simple contrariedad entre el acto jurídico y la ley, esa disparidad debe ser evidente, ostensible, contraria en grado sumo al ordenamiento jurídico.

Más recientemente recordó la Corte que cuando la ley exige como requisito para la actualización del tipo penal de que se trata, que la ilegalidad sea manifiesta, "significa que no todas las decisiones ilegales son prevaricadoras por esa sola condición. En todo caso se necesita comprobar que la contradicción con el derecho aplicable sea de tal gravedad y magnitud que aún en casos de temas de complejidad interpretativa, hasta el sentido común resultaría lesionado. Una cosa es equivocarse en la aplicación de la ley y otra muy distinta utilizarla para desconocer su contenido y alcances con propósitos que le son ajenos. "l

3.3. Lo dicho en último lugar significa que el acto jurídico debe manifestarse no como producto de la torpeza, el desconocimiento o el error, sino de un obrar consciente y voluntario dirigido a contrariar la ley a través de la resolución, el dictamen o el concepto emitidos. Valga decir, que se actuó con dolo.

De lo que se precisa, entonces, conforme con la doctrina de la Sala de Casación Penal, es que el sentenciador realice una ponderada valoración acerca de los elementos que configuran el delito de prevaricato por acción, esto es, que la conducta cuestionada provenga de un acto con falta de sindéresis, es decir, un acto tan desfasado o irracional que conlleve su censura; por lo tanto es la sentencia el momento procesal indicado para evaluar el aspecto subjetivo de la conducta y determinar si el agente procedió con dolo, y sólo en el caso en que exista la certeza de que el procesado actuó de manera consciente y voluntaria, hay lugar al proferimiento de un fallo adverso a los intereses del reo." 


\section{Discrecionalidad en la decisión judicial}

¿Qué significa aquí discrecionalidad? Con este término aludimos a la libertad de que el juez disfruta a la hora de dar contenido a su decisión de casos sin vulnerar el Derecho. “...Por tanto, cuando afirmamos que tal discrecionalidad existe en algún grado, queremos decir que el propio Derecho le deja al juez márgenes para que éste elija entre distintas soluciones o entre diferentes alcances de una solución del caso. Así pues, si hay discrecionalidad significa que al juez las soluciones de los asuntos que decide no le vienen dadas y predeterminadas enteramente, al cien por ciento, por el sistema jurídico, sino que éste, en medida mayor o menor, le deja espacios para que escoja entre alternativas diversas, pero compatibles todas ellas con el sistema jurídico..." (Garcia Amado, 2006, 151).

Tal cesión de espacios decisorios al juez, semejante campo para su decisión discrecional, puede deberse a dos causas: o bien a que las mismas normas hayan querido expresamente remitir al juez la fijación de la pauta decisoria, caso por caso, como cuando son esas mismas normas las que dicen que en un determinado asunto el juez fallará discrecionalmente, decidirá en equidad, etc.; o bien a que las normas jurídicas, prácticamente todas, están hechas de un material lingüístico que es por definición poroso, abierto, indeterminado en alguna medida, por lo que siempre pueden aparecer casos cuya solución resulte dudosa o equívoca a la luz de dichas normas, debiendo el juez concretarlas y completarlas por vía de interpretación o integración. En lo que sigue atenderemos principalmente a esta última causa posible de discrecionalidad judicial. 
Durante mucho tiempo, como veremos, se admitía con dificultad que el juez pudiera disponer de campo para sus discrecionales opciones, aun dentro de los márgenes que la ley deje abiertos por razón de su materia prima, el lenguaje. Y hoy algunas influyentes teorías del Derecho vuelven al rechazo de la discrecionalidad. Pero, entretanto, ha ido quedando claro que la libertad que los jueces pueden usar en su labor tiene dos manifestaciones, una positiva y admisible, la otra negativa y rechazable. La primera recibe el nombre de discrecionalidad y, repetimos, alude a aquella medida de libertad decisoria del juez que resulta inevitable e ineliminable de su cometido, por causa de los caracteres mismos que posee la materia prima de las normas, el lenguaje ordinario. La segunda, que se debe combatir, se denomina arbitrariedad.

Una decisión judicial es arbitraria cuando el juez decide libremente, sí, pero concurriendo todas o alguna(s) de las siguientes situaciones:

- Vulnera las pautas decisorias que el sistema jurídico le fija para el caso, en lo que dichas pautas tengan de claras y terminantes. Conviene aquí hacer una muy elemental aclaración. Que ninguna norma general y abstracta sea capaz de determinar al cien por cien la solución de todos los casos que prima facie se le puedan someter, que respecto de cualquier norma pueda haber casos dudosos cuya solución no es clara y para los que quepan, con igual respeto de las normas, soluciones diversas entre las que el juez tenga que optar, no significa que a veces no haya casos claros y tipifica como delito el robo que se realice valiéndose de armas, cabría discutir si un palo o un puñal de juguete con apariencia real son o no son armas a tales efectos, con lo que respecto de esos casos puede pensarse que el juez puede elegir entre el sí y el no, en función de cómo interprete 
el término "arma" que en la norma figura; ahora bien, nadie en su sano juicio dudaría de que si el ladrón se vale de un fusil perfectamente real, cargado y montado para disparar, el robo acontece mediante el uso de un arma, pues no cabe razonablemente, en modo alguno, negarle a dicho fusil tal condición.”... Así que el juez que dijera que ese fusil no es un arma estaría incurriendo en arbitrariedad, pues nada hay más arbitrario que la negación de la perfecta evidencia..." (Garcia Amado, 2006, 153).

- Cuando el juez no da razón ninguna de su fallo o cuando su motivación del mismo contiene razones puramente inadmisibles, ya sean por absurdas, antijurídicas o incompatibles con los requerimientos funcionales del sistema jurídico. Un juez que, por ejemplo, fundamentara expresamente su fallo en cosas tales como una revelación divina, los contenidos de una determinada religión, los postulados de un determinado partido político, sus gustos particulares o su personal sentido de la justicia estaría incurriendo en arbitrariedad en este sentido, tanto o más que el que se abstiene de motivar su fallo.

Después de estas precisiones conceptuales, puede quedarnos claro que la discrecionalidad judicial no necesariamente es mala (aunque hay doctrinas, como vamos a ver, que tratan de evitarla por completo), y muchos creemos, en todo caso, que es inevitable. Por el contrario, la arbitrariedad ha de perseguirse siempre, es el antivalor judicial por excelencia.

Sentado esto, podemos ya realizar un pequeño repaso histórico y comprobar qué doctrinas han negado y niegan la discrecionalidad judicial y cuáles la han presentado como inevitable 


\section{Casos difíciles}

La existencia inevitable de estos casos difíciles en la práctica de aplicación judicial del derecho, constituye el fundamento de la llamada tesis de la discrecionalidad judicial. “...La distinción entre casos fáciles y difíciles resulta crucial para las posiciones positivistas. Es lo que permite afirmar que la interpretación, en tanto que actividad parcialmente creativa, constituye una actividad excepcional en la tarea de aplicar judicialmente el derecho. La distinción entre el derecho que es y el derecho que debe ser requiere diferenciar las actividades de aplicar el derecho (casos fáciles) y de crearlo (casos difíciles)...” (Marmor 2001 cf. Bonorino \& Peña, 2006: 93).

Manuel Atienza (1993 cf. Bonorino \& Peña, 2006: 94) se vale de la distinción entre caso fácil y caso difícil para analizar una serie de fallos tomados de la práctica judicial española, en un libro reciente destinado a servir de apoyo en las instituciones educacionales intermedias. A lo largo de la exposición va delimitando el alcance de cada una de las expresiones y refinando la clasificación inicial. En el inicio de su trabajo aclara que "... los casos jurídicos suelen clasificarse habitualmente en casos fáciles o rutinarios y en casos difíciles.

“...La distinción es, por supuesto, útil, pero no siempre es fácil de trazar...". Más adelante en su exposición propone trazar la distinción de la siguiente manera: "Un caso es fácil cuando, aplicando los criterios de lo que he llamado "racionalidad formal", el resultado es una decisión no controvertida. Un caso, por el contrario, es difícil cuando, al menos en principio, puede recibir más de una respuesta correcta: el caso plantea la necesidad de armonizar entre sí valores o principios que están en conflicto, y se 
presentan diversas soluciones capaces de lograr un equilibrio, en cuanto que no sacrifican ninguna exigencia que forme parte del contenido esencial de los principios o valores últimos del ordenamiento..." (Atienza 1993 cf. Bonorino \& Peña, 2006: 94).

Para entender esta caracterización debemos aclarar la forma en la que el autor analiza la noción de racionalidad formal en otros trabajos. Atienza (1993 cf. Bonorino \& Peña, 2006: 94) define la racionalidad formal por la presencia de las siguientes notas:

- Respeto a principios de consistencia lógica, universalidad y coherencia;

- Utilización como premisas de algunas de las llamadas fuentes de derecho vinculantes.

- Reconocimiento de los hechos probados en forma debida.

- "No utilización como elementos decisivos de la fundamentación de criterios éticos, políticos, etc. No previstos específicamente (...)"

Por último, Atienza afirma que existe un tercer tipo de casos, a los que llama casos trágicos, que surgen "... cuando en relación con el mismo no cabe tomar una decisión que no vulnere algún principio o valor fundamental del sistema".

A continuación, un breve resumen, de lo que en lo atinente con la interpretación de la Ley han dicho juristas como: Savigny, Rudolph Von Ihering y la evolución jurisprudencial ampliamente conocida de la Honorable Corte Constitucional en éste sentido.

\section{Teorías de la interpretación de la ley, fines y consecuencias}

“...La interpretación no es un problema frio o técnico del Derecho. Se trata más bien de uno de los problemas capitales de la cultura humana que tiene que ver, incluso, con la identidad personal y moral de los individuos y grupos humanos, su origen tiene 
que ver con una característica fundamental: desde hace varios siglos, muchas comunidades han escogido incorporar, en textos escritos sus creencias y directivas normativas más importantes bien sea religiosas o jurídicas. De esta manera, en general se pasó de la oralidad de la norma a la escrituralidad (de la lex non scripta a la lex scripta) como forma de control social...” (López, 2006: 14)

Solo hasta los siglos XVIII y XIX se empezó a hablar de manera sistemática de una hermenéutica crítica por contraste con la simple exégesis o comentario de los textos: “...no se hablaba entonces del problema hermenéutico, considerado en si, sino más bien de ars interpretandi, de sensus scripturae, de regulae interpretationis o simplemente de exégesis...” (René 1965 cf López, 2006, 82).

Si bien la historia a nivel de la interpretación de las normas jurídicas se señala en el acápite anterior de manera exegética, progresivamente y más que llegar a una verdadera hermenéutica jurídica, se pasó a interpretar el sentido de la escritura. Y todas las áreas del derecho seguían esta corriente, pues era el manejo y la consideración de entender que la norma en su sentido literal contenía todas las posibles situaciones que dan origen a la decisión. Pero posteriormente, cuando surge la hermenéutica jurídica, para muchos de los tratadistas y juristas de la época, se entendió como un problema, porque al permitir una interpretación amplia y más allá de las palabras de la norma, daba paso y campo a la discrecionalidad de la cual hoy se habla.

En el campo del derecho Carlos Federico Savigny (cf López, 2006, 120). adoptó gran parte de los logros alcanzados en otras áreas de la cultura a la hermenéutica del derecho. Para él "es la interpretación un arte que se aprende por el estudio de los 
grandes modelos que la antigüedad y los tiempos modernos ofrecen en abundancia, al contrario de lo que sucede con respecto a la teoría de éste arte, respecto a la cual por circunstancias accidentales nos encontramos sumamente pobres."

La metodología tradicional de Savigny, con la importancia supérstite que tiene en el derecho contemporáneo, puede resumirse así: postula los cuatro elementos (gramatical, lógico, histórico y sistemático) y desfavorece de manera muy clara los elementos finalista y consecuencialista.

Esta teoría tradicional de la interpretación será fuertemente resistida en el derecho constitucional contemporáneo donde los elementos finalista y consecuencialista han venido ganando fuerza de manera indiscutible.

\section{Interpretación moderna}

El primer autor que claramente empieza por criticar la insuficiencia de los cuatro elementos planteados por Savigny, es Rudolph Von Ihering (1990), según él a Savigny se le debía criticar su excesiva concentración en el texto escrito del derecho (aunque no era un mero exegeta) y su flagrante olvido de los problemas prácticos que las normas buscan resolver, en la vida. Por tal razón Ihering empieza por criticar el "Conceptualismo" de Savigny y a proponer un mayor énfasis en el "fin" del derecho y de las normas.

Comienza por señalar que el fin debe entenderse en general como una adecuada comprensión del problema social que la ley busca resolver y una evaluación de, si en el caso concreto, la aplicación de la norma se traduce en las consecuencias que se desprenden de su propósito. 
Desde este punto de vista el intérprete jurídico está en la obligación de entender la política pública, económica, social, que la ley encarna e interpretar la norma para buscar de manera primaria la efectiva realización de dicha política.

De esta manera el juez está autorizado a velar por la realización de las consecuencias específicas de la política encarnada en la ley, incluso si para ello debe sacrificar el texto, la historia, la lógica o el sistema. Todos estos arbitrios de interpretación formalista deben ceder el paso a una consideración práctica del fin de la norma y a la evaluación de si la norma interpretada conduce a las consecuencias queridas.

La metodología antiformalista de interpretación planteada por Ihering, en principio, es más libre que la planteada por Savigny. Esa mayor libertad significa en concreto que un apego excesivo al texto de la ley, en desmedro de los fines sociales, se traduce, no en el respeto del principio de legalidad; sino en un fetichismo de la ley escrita. La interpretación antiformalista, no es discrecional o subjetiva, le exige al juez un mayor conocimiento de las realidades en las cuales debe operar la norma. Esta corriente que recorrió el mundo en el primer cuarto del siglo veinte, le exigía al juez una mayor preparación interdisciplinaria en economía, sociología, sicología, estadística para poder identificar los fines y propósitos de la ley a la luz de las necesidades

contemporáneas y calcular correctamente si una cierta interpretación, aplicación o integración de la norma produciría las consecuencias que su fin exigía.

\section{Métodos de interpretación de la Constitución}

Textualismo y literalismo: Las escuelas contemporáneas de interpretación constitucional, en general son teorías que buscan (i) o hacer listas eclécticas de estos elementos (ii) o 
afirmar la preponderancia de alguno de ellos, Así por ejemplo quienes piensan que la fidelidad a la constitución es fundamental, aseguran que la constitución debe ser interpretada de manera predominantemente textualista. Sin embargo esta estrategia de interpretación no es muy útil porque la constitución se caracteriza precisamente por estar conformada por textos abiertos, o indeterminados donde la sola Letra de la ley no parece resolver casos concretos (Dworkin, 1984).

Los autores, por tanto, con frecuencia hacen una distinción dentro de las normas jurídicas: hablan de reglas por un lado y de principios por el otro. Las reglas son pues normas que típicamente se encuentran en los códigos de derecho común, se trata al decir de Kelsen (1934), de proposiciones Jurídicas en las que existe un antecedente (un hecho típico claramente definido) y un consecuente (una consecuencia jurídica expresa unida al hecho típico antecedente). La regla por tanto requeriría aparentemente poca interpretación ya que el juez solo tendría la obligación de subsumir hechos en la regla para aplicar la consecuencia al caso concreto. Los "principios" en cambio, parecen ser normas jurídicas en las que (i) no hay relación de subsunción entre ellos y consecuencias entre (antecedente y consecuente) (ii) y su contenido se expresa en lenguaje moral y político de alta abstracción sin que se especifiquen los casos o consecuencias de su aplicación.

Historicismo y Originalismo: Los textos indeterminados o abiertos tienen que ser especificados mediante el empleo de criterios adicionales. Así, para algunas constituciones del mundo, el texto es usualmente contemplado con cuidadosos estudios históricos sobre el significado original de la constitución. A esta postura se le denomina 
comúnmente "originalismo o historicismo", y es una estrategia de interpretación muy popular en E.E.U.U., como una forma de impedir la intromisión de la discrecionalidad en la actividad judicial. Este originalismo, en el que se subraya el papel fundamental en la interpretación del establecimiento de la constitución de Filadelfia no parece ser de recibo para el caso colombiano por varias razones fundamentales.

Una estrategia originalista no tiene sentido para una constitución tan nueva como la colombiana, en la que se puede asumir que los valores históricos originales son los nuestros propios. En ese sentido no hay una voluntad constitucional en nosotros que sirva como forma de controlar la intromisión ilegítima de juicios de valor personal dentro del texto constitucional. En Colombia la Corte Constitucional utilizó en sus primeros años de jurisprudencia el criterio histórico con alguna frecuencia ${ }^{2}$, con el paso del tiempo, sin embargo la Corte se ha vuelto cada vez menos Historicista por las dificultades que se han señalado. Esta investigación histórica, igualmente ha sido raramente empleada por los jueces colombianos de instancia dadas las dificultades que para ellos presenta el encontrar e investigar la historia del constituyente del 91.

Sin embargo, es seguro concluir, que tanto positiva como normativamente, el método historicista $\mathrm{u}$ originalista no ha prevalecido en la tradición constitucional colombiana.

Interpretación Sistemática y Finalista: En términos generales podría decirse que por fin, interpretación finalista, o interpretación teleológica se denomina a la técnica mediante la cual la aplicación de cualquier texto legal, requiere una previa identificación del

\footnotetext{
${ }^{2}$ Ver al respecto sentencias: T-409/92 en la que se niega en Colombia la Objeción de conciencia; C-453/94; en la sentencia C-511/94 critica el método historicista, indicando: "por ello debe primar en general una interpretación sistemática y finalista del texto constitucional tal y como fue aprobado y no recurrir a hipotéticas intenciones de la Asamblea nacional Constituyente."
} 
propósito o valor que la norma busca proteger. Es más, la aplicación formalista del texto debe ceder ante el propósito, cuando por alguna circunstancia, el texto parezca llevar a resultados contrarios a los que conduciría el fin normativo.

Este propósito o valor, en general, no se refiere a la noción de intención del legislador (que es usualmente uno de los arbitrios de interpretación que hemos llamado originalista), sino al propósito o valor objetivo y contemporáneo, esto es, al fin existente o presumible dentro de la ley o del sistema jurídico y que mejor respondan a las nociones contemporáneas de corrección moral y política que la comunidad tenga regulada.

Un pequeño ejemplo (aunque con modificaciones) de Hart (1968: 332), puede ser útil para entender la interpretación finalista: supóngase que una regla municipal prohíbe "la entrada de vehículos al parque" so pena de una sustanciosa multa, desde una perspectiva meramente formalista la norma hace una prohibición sin cualificaciones ni excepciones. Supóngase, sin embargo, (i) que la policía empieza a hacer rondas en motocicletas, (ii) que ocasionalmente entran ambulancias a recoger pasajeros, y (iii) los niños juegan en el parque con sus juguetes motorizados.

¿A quién se le ha de imponer la multa?, bajo una lectura textualista de vehículo, a todos. Este resultado, sin embargo, parecería injusto y probablemente contrario a la norma. Porque el texto de la norma arguye el finalista, no es nada sin consideración del fin o valor que la norma protege. Así, si la norma busca la protección de la seguridad de quienes van al parque, los casos (i) y (ii) no recibirían multa. El caso (iii) sólo recibiría multa si los juguetes de los niños fueran de una dimensión y cilindrada suficiente para amenazar dicha seguridad. 
En cambio, por ejemplo, si el propósito no fuera la seguridad, sino la tranquilidad, el caso (iii) quizás dependería del ruido o bullicio que los juegos de los niños ocasionarían.

La crítica más importante a los criterios finalista y sistemático basado en la cláusula de estado Social de Derecho, es esta: se acepta que éste es un objetivo legítimo en el constitucionalismo colombiano; pero se advierte, de otra parte, que no es el único y prevalente entre los fines constitucionales y que sería posible identificar otros igual o más importantes.

Frente a un monismo de fines, entonces, los autores, jueces, políticos empiezan a hablar de un pluralismo de fines y la respuesta frente a un pluralismo de fines no es la interpretación meramente finalista y sistemática (conforme al fin predominante absoluto) sino la técnica del balanceo o ponderación entre derechos, fines, valores e intereses, según reconocen sus promotores, una forma más desarrollada de hermenéutica teleológica (Alcinicof, 1996).

La postulación de principios generales de interpretación fue una de las formas en que la Corte buscó guiar y unificar la jurisprudencia de sus inferiores, entre ellos: " $L a$ Cláusula de Estado Social de derecho” y otras máximas como "prevalencia del derecho sustancial sobre la formalidad", fueron y son determinantes en la dirección del Derecho Constitucional colombiano.

Adicionalmente, la Corte Constitucional buscó darles a los jueces mecanismos adicionales que los ayudaran en la interpretación. Esta labor de liderazgo se ejerció mediante la creación jurisprudencial de dos técnicas hermenéuticas que buscaban orientar 
a los jueces inferiores en su labor de interpretación constitucional; estas dos técnicas eran: la doctrina del precedente y la segunda los tests.

Los objetivos interpretativos de la técnica del precedente siguen siendo dos fundamentales:

- Lograr que los jueces tengan una comprensión finalista y sistemática de la constitución.

- Lograr que los jueces apliquen no solo las reglas constitucionales; sino igualmente las sub-reglas jurisprudenciales en que dichas reglas se especifican.

La técnica del precedente, no es en realidad una metodología independiente de interpretación; sino una fuente de derecho donde los jueces pueden identificar la existencia de subreglas constitucionales y los procesos interpretativos mediante los cuales se ha llegado a la determinación de tales subreglas.

De otra parte, el objetivo de los tests, como el de igualdad y el de razonabilidad, por ejemplo, es del de guiar a los jueces en la labor de ponderación o balanceo, en aquellos casos por demás muy frecuentes, en los que hay derechos e intereses contrapuestos sin que pueda decirse que uno de ellos pueda prevalecer absolutamente sobre el otro.

\section{El positivismo jurídico de Hans Kelsen}

Como es bien sabido, la norma fundamental Kelseniana es el criterio que se utiliza en el marco de la Teoría Pura del Derecho para identificar el Derecho. La norma fundamental - que es una norma presupuesta - es también el fundamento de la validez del Derecho. 
Kelsen, está en contra de la utilización de ciertos principios normativos de carácter ético que se venían utilizando en la jurisprudencia ${ }^{3}$.

Cuando existen leyes que tratan de los problemas que se plantean ante los jueces, estos deben decidir conforme a los criterios preestablecidos. En el caso de que no exista una ley aplicable, o un precedente, o una decisión del pasado, entonces el positivismo se divide. Kelsen - afirmaría por ejemplo- que el derecho siempre ofrece respuesta porque el juez debe rechazar la demanda cuando no encuentra en el derecho una norma aplicable, ésta sería la posición más fuerte del positivismo decisión más aceptable ya que mantiene que las decisiones del pasado determinan el presente (Kelsen 1934). Los jueces y demás órganos decisorios están sujetos a las normas jurídicas y a las decisiones explícitas del pasado. Cuando no hay decisión explícita, no hay discreción judicial.

El autor comparte el criterio de Kelsen aun en que los enunciados de derechos y deberes se deben rechazar y mantener el pleno criterio normativo. Pues si se analiza el aspecto puramente penal, partiendo de que, en el campo penal se analizan los hechos, esta interpretación debe estar basada en un aspecto normativo aplicable al caso concreto, formando así un único sistema para las decisiones.

No comparto lo expuesto en crítica por Hart frente a Kelsen como un error de éste que da origen a la teoría monista.

\footnotetext{
${ }^{3}$ Según lo expresara Kelsen, en su carta a Renato Treves, en el punto tres de ella, citado por Ulises Schmill
} 


\section{Positivismo metodológico}

Herbert Hart es la figura más importante de la filosofía jurídica anglosajona del siglo XX. Muestra que las críticas que el realismo extremo formula a cualquier variante de normativismo se fundan en una inaceptable concepción de la actividad jurisdiccional.

La misma magnifica los elementos ineliminables de discrecionalidad presentes en toda decisión judicial por la textura abierta de los lenguajes naturales en los que se expresan las reglas jurídicas. Esto conduce a Hart (1968) a esbozar una teoría de la decisión judicial.

En tales circunstancias, no podría existir argumento inteligible o desacuerdo acerca de lo que es el derecho de un sistema jurídico particular o considerado en términos generales. "Solo me resta decir que nunca pasó por mi cabeza tal teoría semántica y que mi teoría de la regla de reconocimiento, no descansa en el significado de la palabra "Derecho" o en una teoría del significado". Se apoya en consideraciones acerca de la necesidad de un consenso judicial como criterio de validez del derecho y en la exigencia de que deberían existir interpretaciones comunes entre los jueces (Doxa, 1988).

El Juez se puede encontrar con lagunas, y en éste caso puede decidir conforme a su discreción (Hart, 1968: 138). En principio los jueces están determinados por decisiones del pasado, siempre y cuando estas decisiones se hayan producido. Si no hay decisión previa, entonces el juez no se ve limitado y decide discrecionalmente.

Hart subrayó en sus términos "textura abierta" de la separación conceptual entre derechos y moral, numerosas reglas jurídicas y la necesidad para los tribunales de ejercer 
una limitada función del derecho o discrecionalidad. En una de sus conferencias refiere definición y técnica en la jurisprudencia, para las decisiones judiciales.

Muchas teorías cercanas a la discrecionalidad y teorías sobre la jurisprudencia expresan su interés en el tema de investigación, pero no se encuentran de forma concreta referidas a la discrecionalidad en cuanto al derecho penal, pues estas teorías están basadas en sistemas de gobierno socialistas, conservadores o un sistema político de la época y Hart profesaba una teoría filosófica cuál era su profesión. Si bien desarrolló temas de discrecionalidad y de decisión judicial, no acepta mediante ninguna razón sostener que la jurisprudencia y la teoría jurídica deben presentarse bajo fórmulas moralmente justificables.

\section{Doctrinas y planteamientos de Dworkin y el Neoconstitucionalismo.}

“...Hay tres doctrinas que, grosso modo, coinciden en la siguiente idea: el sistema jurídico se compone de estratos, y en tales estratos hay que distinguir ante todo un estrato superficial y otro profundo o subterráneo. En el primero se hallarían las normas de derecho positivo, en su formulación más convencional, es decir, los enunciados jurídicos que el legislador produce y que se agrupan en códigos, leyes, reglamentos... Pero por debajo de ese nivel, sosteniéndolo y dándole su inspiración, su sentido último, su razón de ser y la perfección que le falta se encuentra el estrato profundo, cuya materia ya no es lingüística sino axiológica, no empírica sino ideal, y no imperfecta, esto es, lagunosa, incoherente y oscura, sino perfecta, pues contiene solución única, consistente y definida para cualquier caso..." (Dworkin, 1984, 66 a 98). 
Si bien, la doctrina y el planteamiento de Dworkin se ajustan a sistemas de gobierno o sistemas jurídicos estáticos tales como el socialismo, el comunismo o los demasiado conservadores, lo que permite afirmar que efectivamente en ese estrato profundo o subterráneo, encuentra la decisión perfecta, única y constante para cualquier caso. Lo mismo no se puede afirmar de sociedades como la nuestra o que están en constante cambio, de principios, valores y de sistemas procesales. Aquí se parte de valores inmutables, cuando la realidad nuestra nos enseña que ni aún los valores en la sociedad son inmutables.

Permítasenos seguir con las imágenes como modo de ilustrar o representar la compleja visión del Derecho que mantienen estas doctrinas. Podemos ver su analogía con un edificio de varios pisos. Por muy hermoso que sea y por muy perfecta que resulte su estructura externa, no se sostendría si no estuviera asentado en unos firmes cimientos. Pues bien, los enunciados jurídico-positivos son como los pisos de ese edificio y los hay más bajos (por ejemplo, los reglamentarios) y más altos (por ejemplo, los legales), hasta llegar al piso superior (la Constitución). Pero lo que materialmente sostiene todo eso, lo que lo cimenta, son los valores, ciertos valores sin cuyo sostén la hermosa construcción se vendría abajo y quedaría convertida en puro escombro inútil.

Es como si bajo la pirámide Kelseniana excaváramos y encontráramos los pilares subterráneos que la sostienen, pilares hechos de materia valorativa. Con un añadido: esa base no sólo ofrece el sustento de lo que hay arriba, la ley positiva, sino también su perfecto complemento, pues todo lo que uno no encuentre, o no encuentre claro, en los pisos superiores del edificio o la pirámide, puede hallarlo perfectamente dispuesto y 
utilizable en ese sustrato de fondo, en esa base axiológica, mediante la cual el sistema jurídico se cierra y se perfecciona (Dworkin, 1984, 66 a 98).

Vemos, en resumidas cuentas, que estas doctrinas axiológicas desdoblan la naturaleza del Derecho y, al tiempo y complementariamente, desdoblan en dos la epistemología jurídica, el tipo de conocimiento que se requiere para saber del Derecho. Hay siempre una naturaleza superficial y una naturaleza profunda del Derecho, constituida la primera por enunciados jurídico-positivos y la segunda por valores. Y, al tiempo, hay un conocimiento superficial del Derecho, propio de quienes sólo ven en él enunciados que pueden ser comprendidos en sus términos e interpretados, con márgenes de elección discrecional, en sus indeterminaciones; y un conocimiento profundo del Derecho, al alcance sólo de quien domine el método de excavación o buceo que permite superar el dato superficial, equívoco, dudoso y, a veces, hasta falso o engañoso, y captar las verdades plenas e indubitadas que en el fondo del sistema se guardan, al modo de solución correcta para cada caso que al Derecho se someta. Ese método se solía describir como capacidad que nuestra razón posee para escuchar los dictados grabados en nuestra naturaleza, o en el orden inmanente a la creación.

Para la Jurisprudencia de Valores las normas legales o de derecho positivo, es decir, los enunciados jurídico-positivos, contenidos en la Constitución, las leyes, los reglamentos, etc., tienen su fundamento y perfecto complemento en todo un sistema articulado y consistente de valores que les subyace. Esos valores no son parte separada del Derecho, aditamento externo, sino parte constitutiva y esencial del Derecho mismo. Gracias a esos valores los graves problemas que para su aplicación presenta el derecho 
positivo se tornan resolubles cuando se trata de aplicar a los casos el conjunto total del Derecho, incluyendo tales valores.

Así, las lagunas no habrán de resolverse desde la discrecionalidad del juez que no encuentra norma positiva, pues podrá hallarla prepositiva, yacente en ese sustrato valorativo; las antinomias se darán sólo en la superficie, al nivel de los enunciados, pues en su fondo valorativo el Derecho brinda solución coherente y única para cada caso, ya que la justicia, en tanto que super valor, no puede ser contradictoria o equívoca; y, sobre todo, lo que en el plano del lenguaje de las normas positivas puede dar lugar a dudas interpretativas, se vuelve claro cuando se atiende a ese fondo material de valores que alienta bajo cada norma e inspira su lectura desde los casos, por lo que interpretar ya tampoco es elegir, más o menos razonadamente, entre significados posibles de la norma, sino conocer, descubrir, allá en el fondo del Derecho, en su subsuelo de valores, en su cimiento axiológico, la verdadera solución de cada caso.

Ese camino iniciado por la Jurisprudencia de Valores tendrá las etapas principales de su ulterior desarrollo en Dworkin (1984) algunos de los llamados neoconstitucionalistas. No quiero, para nada, decir que Dworkin construya su doctrina apoyándose en semejante antecedente, pues todo hace pensar que nada sabía de él, y, si algo sabía de eso (o, por ejemplo, del parentesco de su teoría de los principios con la obra de Josef Esser, otro alemán, de 1959), bien lo disimuló al omitir toda cita o referencia. Pero, sea como sea, la aportación de Dworkin (1984) va a consistir en acercar a la sociedad esos valores extrapositivos, pero jurídicos, para los que la Jurisprudencia de Valores aún buscaba un anclaje en exceso metafísico y ahistórico. 
Ahora nos resta examinar el problema epistemológico. ¿Pueden conocerse con precisión esas normas morales que son al tiempo jurídicas, aunque no sean derecho positivo? ¿Podemos hallar en ellas respuesta exacta y precisa para absolutamente cualquier caso cuya solución de derecho positivo nos resulte dudosa o nos parezca inconveniente? La respuesta de Dworkin es sí. Para este autor el sistema jurídico, con esa doble composición que ya sabemos, contiene en su seno una y sólo una respuesta correcta para cada caso que se le somete. Por tanto, no hay sitio para discrecionalidad ninguna y la labor del juez no es propiamente decisoria sino, en puridad, cognoscitiva: el juez aplica Derecho, sí, pero no optando entre las soluciones que le parezcan compatibles con la ley o coherentes con ella, sino averiguando, descubriendo, conociendo, cuál es exactamente y en puridad la solución única que el sistema jurídico reserva para cada caso. Si hay casos difíciles no es porque su solución no esté perfectamente predeterminada en el sistema jurídico, sino porque es difícil hallarla o complicado fundamentarla.

¿Y quién puede conocer esa solución única e indubitada que en el fondo del Derecho yace para cada caso, esperando ser descubierta? Pues podría conocerlas todas y con total seguridad un juez perfecto. Hasta nombre le pone Dworkin (1984) a ese juez ideal: se llama Hércules. El juez Hércules es aquel juez absolutamente sabio y experto, que sabe todo de todo, al menos todo lo necesario para dar con esas soluciones que el común de los mortales difícilmente puede conocer con seguridad. Como ninguno somos verdaderamente Hércules, más bien vulgares mortales, tampoco podemos saber exactamente qué es eso que idealmente deberíamos saber para estar en condiciones de saber lo que hay que saber. Pero si fuéramos Hércules lo sabríamos y, con ello, daríamos 
(al menos si fuéramos jueces) con la única respuesta correcta para cada caso. Ciertamente el juez Hércules es un juez ideal, omnisciente, y que precisamente por ser omnisciente, sabedor de todo, sabe también cuál es la correcta solución judicial de cada caso. En cambio, un juez de carne y hueso será tanto mejor juez y, consiguientemente, tanto más verdaderas sus decisiones, cuanto más su saber se aproxime al saber ideal de Hércules.

Dworkin (1984, 66 a 98) sostiene que el derecho no solo está compuesto por normas; sino también por directrices - que tienen como objetivo un bien colectivo - y principios, - que son razones para decidir en un modo determinado. Los principios acostumbran a ser de carácter muy general, cita como ejemplo que en nuestra constitución consagra un principio de una forma muy general como es el principio de igualdad, el cual supone el tratamiento igual de lo que es igual y desigual lo que es desigual.

Las dos mejores aportaciones de Dworkin a la filosofía jurídica son: El derecho como concepto interpretativo, lo cual constituye la mejor arma contra el positivismo jurídico y constituye el primer peldaño de su construcción y el segundo, es el enfoque del derecho desde la perspectiva de integridad.

Frente al planteamiento de Dworkin habría que preguntarse. Por qué los jueces tienen que decidirse respecto a principios y no conforme a directrices que tienda a preservar el bien colectivo. En los ordenamientos jurídicos positivos, no existe ninguna regla que obligue a los jueces a juzgar conforme a los principios.

Un Hércules II, podría defender la idea de que los casos difíciles no solo se deben resolver conforme a los principios que históricamente definen esa comunidad; sino 
conforme a directrices, políticas, estándares y principios vigentes en esa sociedad, si eso se acepta y entonces el juez ideal tiene discreción, ¿Cuál es la mejor respuesta?

\section{Teoría de la argumentación jurídica}

En el libro "Teoría de la Argumentación Jurídica”, (Alexy, 2001, 56) presuponía todo un concepto no positivista del derecho que sin embargo no quedaba desarrollado.

La dignidad humana tiene una estructura distinta a la de los otros derechos fundamentales. Toda intromisión en la dignidad humana significa una lesión.

Plantea que los Principios son mandatos de optimización y se conectan con la interpretación de los derechos Constitucionales.

El Derecho consiste en tres elementos: (1) la legalidad en conformidad con el ordenamiento. (2) la eficacia social. (3) la corrección en cuanto al contenido. El primero representa la institucionalidad del derecho, el segundo su facticidad y el tercero la moralidad, establece una conexión necesaria con el derecho.

Existen principios que tienen por objeto derechos fundamentales y principios que tienen por objeto bienes colectivos. Estos principios entran en colisión con frecuencia y no es posible resolver esta colisión sin la ponderación. No defiende una prioridad estricta entre estos. Cita ejm. Libertad de expresión y derecho a la protección de la personalidad; derecho a la propiedad y la protección del medio ambiente.

El óptimo de Pareto, exige que se consideren los principios de adecuación y de necesidad como principios particulares del de proporcionalidad, el cual enseña que el fundamento jurídico para una intromisión tiene que ser tanto más fuerte, cuanto más intensa sea la intromisión. Esto vale, tanto para la colisión entre derechos fundamentales, 
como para la colisión entre derechos individuales y bienes colectivos. Para justificar una débil intromisión en el derecho a la propiedad basta con que por medio de ella se produzca una mejora del medio ambiente relativamente poco importante.

Desde que apareció su “Teoría de la Argumentación Jurídica”, (Alexy, 2001,60) después de todo ese tiempo que ha transcurrido, consideró tres puntos importantes: El primero es que con las decisiones jurídicas y con sus argumentaciones se erige la pretensión de corrección, con el transcurso del tiempo esa afirmación la ha ampliado hasta llegar a la tesis general de que el Derecho erige necesariamente una pretensión de corrección.

El Segundo punto es la tesis del caso especial, viene a decir que el discurso jurídico, por su característica vinculación con la Ley, al precedente y a la dogmática, es un caso especial del discurso práctico general. Eso lleva a la doble naturaleza del Derecho. Las vinculaciones a la Ley, al precedente, y a la dogmática definen su carácter institucional y autoritativo. La apertura a la argumentación práctica general le añade una dimensión ideal y crítica. La conexión entre estos dos aspectos lleva a una vinculación entre el Derecho y la moral que es algo excluido por el concepto positivista del Derecho.

El tercer punto y quizás el más importante la tesis de que la argumentación practica racional resulta posible. Lo que demuestra esa posibilidad es el hecho de que se haya construido. La construcción consiste en un sistema de reglas y de formas que viene a explicitar de qué manera la razón puede ser práctica. Se constituye así una alternativa a los extremos del puro objetivismo y del puro subjetivismo. 
El sistema jurídico contiene postulados morales fundamentales que adoptan la forma de derechos fundamentales. Por otro lado, las libertades garantizadas mediante derechos fundamentales impiden que se pueda ir muy lejos en la identificación del Derecho con convicciones morales no compartidas por todos. De esta manera, el Estado Constitucional democrático trata de resolver la vieja tensión entre el Derecho y la moral.

Existen cosas comunes entre la Teoría del Derecho de Dworkin (1984) y la de Alexy (2001), pero el armazón conceptual es bien distinto; aunque puede decirse que ambas teorías son similares en lo sustancial. Así el concepto de principio juega su papel en ambas teorías, el manejo que se hace del mismo varía.

En la concepción de Robert Alexy, los principios constituyen mandatos de optimización; los bienes colectivos pueden también ser objeto de regulación de los principios. Esto lleva a la contestación de la pregunta de si se ha lesionado un derecho fundamental juegue un papel central el principio de proporcionalidad y con ello la ponderación.

En la visión de Dworkin de los derechos como triunfos. También hay diferencias en la determinación de las relaciones entre libertad e igualdad. R. Alexy los considera como principios del mismo rango que pueden entrar en colisión. Pero esto queda excluido de la visión de R. Dworkin que considera la igualdad como la virtud suprema de la comunidad política. Para R. Alexy, el concepto que expresa la armonía a la que se aspira es la corrección. Tanto la igualdad como la libertad están subordinados a esta idea regulativa. 
El Estado Constitucional democrático supone la mejor forma de conectar la argumentación con la decisión desde la perspectiva de los ideales de Libertad, e igualdad fundamentados discursivamente. Ahí juega un papel esencial la ponderación en cuanto forma de aplicación de los Derechos Fundamentales.

\section{El concepto de derecho}

Me referiré ahora a lo que Hart (1968) expresa en su obra El Concepto de Derecho. Para este autor, el derecho es creado según el comportamiento humano y se gesta en las situaciones de la cotidianidad y por la presión social.

A continuación, afirma Hart (1968): “El concepto de obligación se sustenta, no solo nace por presión social, sino en un juego de reglas que reclaman veracidad, honestidad y diversos estadios de lo que consideramos valores".

Un sistema jurídico funciona por la obediencia de los grupos sociales a las reglas, a los criterios y a las pautas de comportamiento.

\section{Sobre la decisión judicial}

Sobre la decisión del juez, Kennedy (1999: 19-21), en su obra "Libertad y Restricción en la Decisión Judicial" cuyo propósito consiste en poner al descubierto el sentido político de la práctica cotidiana de los jueces y de los juristas, afirma que "la finalidad de la crítica es mostrar las profundas inconsistencias internas del derecho, su carácter contingente, y derrumbar el statu quo a través de un examen minucioso de los textos y prácticas pertenecientes a la tradición jurídica. La crítica a la adjudicación se dirige fundamentalmente contra la retórica de la coherencia y la neutralidad. La tesis de Kennedy es que la ideología forma parte esencial del discurso jurídico y el juez es un 
actor ideológico, incluso el que se empeña en guardar fidelidad a la retórica de la neutralidad".

Kennedy $(1999,20)$ cuestiona si existe la coherencia interna de los sistemas jurídicos, así como la neutralidad de los jueces en la aplicación de las normas jurídicas o como creadores de Derecho, inspirados en razones políticas y morales.

Entra a discutir este autor, aspectos como el carácter objetivo o subjetivo de la interpretación jurídica y si existe una intersección o separación entre la política y el derecho en la adjudicación.

Como respuesta a esta discusión, Kennedy $(1999,21)$ afirma: “Cuando se concibe el ordenamiento jurídico como un sistema armónico y completo, la tarea del juez consiste en desentrañar y explicitar la solución que para el caso concreto ya prevé el ordenamiento jurídico. Por el contrario, cuando se entiende el derecho como un conjunto de normas que tienen una textura abierta y que se encuentran en tensión porque protegen intereses de grupos enfrentados, en ellos, el juez no media en forma neutra y puede elegir entre interpretaciones alternativas., es así como las teorías que sostienen la indeterminación del derecho, suelen señalar el carácter subjetivo de la adjudicación".

Para Kennedy (1999), como los jueces son símbolos sociales de autoridad e imparcialidad, cuando hacen un pronunciamiento, la gente tiende a pensar que lo establecido en sus sentencias es lo correcto; Kennedy llamó a este fenómeno "efecto de conversión", entonces, cualquier decisión que tome el juez se hará ver como correcta.

López Medina (2006, 147) en su obra "El Derecho de los Jueces", expresa varias ideas que debemos resaltar acá. Una de ellas es que los derechos fundamentales deben 
predominar al momento en que el juez profiere su decisión. Es decir que debe aplicar el Derecho Constitucional considerando los límites de la responsabilidad decisional.

Con respecto a la creación del Decreto 2700 de 1991 y la Ley 600 de 2000, dice López (2006, 242), se buscó ajustar la legislación para que fuera acorde con los índices de criminalidad en el país.

Asimismo, dice López (2006, 265), la creación de la Ley 906 de 2004 dentro de la nueva legislación, por la necesidad de evitar ambigüedades y erradicar al fiscal como un funcionario más, ya que era un solo funcionario el que manejaba el tema investigativo, escritural, procesal y en general todo lo relacionado con el proceso judicial.

Ahora la fiscalía cumple un papel más específico, es el acusador, y es obligación de los jueces no mostrar una actitud pasiva frente a las circunstancias, sino también, desarrollar la gerencia, la dirección y el control.

Por otro lado, Javier Tamayo Jaramillo (2011, 417), en su libro La Decisión Judicial, no comparte la tesis de que la moral está ligada conceptualmente al derecho positivo y por lo tanto rechaza la tesis de la discrecionalidad absoluta de los jueces; por el contrario defiende el principio de legalidad, cree en un positivismo discrecional que admite que el juez crea derecho en cada sentencia dentro del margen de posibilidades que le brinda la norma con sus interpretaciones posibles, sobre todo en los casos difíciles.

Además, señala que no cuestiona el contenido de los fallos de la Corte Constitucional; sino su método de aplicación del Derecho. "Me parece contraproducente que la Corte haya llegado a tal grado de activismo legislativo que cambie, cree y 
adicione normas, o que las interprete en contravía de los más elementales cánones de interpretación universalmente reconocidos” (Tamayo Jaramillo, 2011, 1397 a 1405).

Un asunto es admitir la existencia de valores y principios en la Constitución, dice Tamayo, y otra cosa es aplicar justicia según un esquema de valores del fallador, sin tener en cuenta las normas positivas, algunas de las cuales son de rango constitucional.

Tamayo (2011, 1397 a 1405) concluye que "es válido dentro de un estado social de derecho, el Neo constitucionalismo (sic) teórico que acepta la existencia de valores, derechos fundamentales y principios en el ordenamiento jurídico positivo; que ellos impregnan el universo normativo en el sentido de que toda norma de rango inferior a la constitución, debe estar acorde con esos valores, derechos y principios, dentro de las restricciones legales necesarias en todo sistema jurídico. Y que el juez, sin caer en el literalismo del positivismo ingenuo inicial, debe respetar la interpretación lingüística de los vocablos que contienen esos principios axiológicos o materiales".

El nuevo derecho, continúa Tamayo (2011), entendido como la aplicación del derecho según principios generalísimos y buscando la justicia substantiva que el juez adapta a cada caso concreto, así haya que dejar de lado las normas escritas, existe mucho antes de 1991. Desde los años 30 en los Estados Unidos ya existía el escepticismo ante las reglas y desde los años 60 en Europa, ya existía el uso alternativo del derecho, inclusive la teoría valorista de la interpretación, que en alguna forma defiende el activismo judicial, existía en Alemania en la década de 1920. Si se revisan las jurisprudencias de los jueces colombianos anteriores a 1991, se verá que siempre han existido interpretaciones legales similares a la mayoría de las sentencias de nuestros días. 
Antes de 1991 también se fallaba en equidad y existían los valores y los derechos fundamentales.

Los antipositivistas atacan un positivismo formalista que ya no existe. El positivismo defiende un margen de creatividad judicial limitada por los textos positivos. El nuevo derecho en cambio, defiende la discrecionalidad absoluta del juez para desconocer las normas positivas y fallar según lo que le parezca correcto.

El nuevo derecho no es más que una ideología política sobre la metodología de aplicación del derecho. El nuevo derecho como teoría, consiste en defender la aplicación de la moral en cada caso concreto, con prescindencia, si es del caso, de las normas positivas vigentes. Es la defensa de un derecho natural, aplicado por el juez según lo que él considere como solución correcta. Detrás de esto, sucede que la justicia se convierte en un arma de lucha política de izquierda o de derecha, mediante la cual los jueces se convierten en verdaderos actores políticos, aplicando, no el derecho vigente, sino la justicia que a ellos les parece correcta.

En general, afirma Tamayo (2011), el NC teórico, mayoritario y respetuoso del principio de legalidad del estado de derecho, es contrario al nuevo derecho, en la medida en que el primero acepta que el juez, al dictar sus decisiones, lo debe hacer dentro del respeto a las normas positivas, así no sea aplicándolas literalmente.

Dice el autor que el nuevo derecho constituye una especial aplicación del derecho que se utiliza para desconocer el principio de legalidad del estado de derecho e introducir la ideología política que quieran, quienes conforman la corte constitucional. Y ese método es muy peligroso porque sirve para legitimar un despotismo de extrema izquierda 
o de extrema derecha; dice igualmente: "La lucha mía en este escrito no consiste en defender una determinada ideología económica o política, sino en defender la seguridad jurídica, pilar fundamental del estado social o liberal de derecho; eso solo se logra con una legislación más o menos previsible, que no dependa del tribunal constitucional”. (Tamayo Jaramillo, 2011, 2096).

Para concluir, insiste Tamayo, en que lo reprochable del nuevo derecho, no es que suponga un sistema político y jurídico basado en principios de centro izquierda como lo propone el profesor López, sino el peligro de que el poder judicial haga y deshaga con la constitución, sin control alguno.

Pueden los defensores del nuevo derecho estar seguros de que en un régimen de extrema derecha o de extrema izquierda, con una corte sumisa, con otra denominación, cierra los medios de comunicación, manipula la constitución y suprime las garantías y libertades con el pretexto de defender el estado de derecho. Si ello sucede, levantaré mi voz de protesta, porque el juez no puede ser una de las tantas formas de lucha de que hablan los totalitaristas de izquierda y de derecha.

El juez debe tener una ideología política y le debe ser respetada, pero no puede poner su investidura al servicio de esa ideología, si con ello desconoce el principio de legalidad, base esencial del estado social de derecho.

Agrega que los casos jurídicos se solucionan mediante la aplicación de reglas legales específicas, ya que la Constitución, rara vez influye en la decisión de los casos jurídicos concretos. Además, según López Medina (2006), en el derecho tradicional la ley frecuentemente viola la Constitución, ya que el proceso de promulgación legal presupone 
el triunfo de mayorías políticas, con frecuencia en abierta violación de derechos de minorías no representadas políticamente.

En cambio, en el nuevo derecho, la constitución tiene aplicación concreta en la solución de casos jurídicos. Además, tiene preferencia sobre la ley, a pesar de los niveles de generalidad que ambos exhiben: un principio constitucional abstracto, solo aplicable a través de un argumento interpretativo, puede triunfar sobre reglas explícitas y concretas que también pretenden regular la situación concreta.

Esto significaría, digo yo, que cada vez que al juez le parezca que, para el caso concreto, la norma perjudica al más débil, debe dejar de aplicarla. Considero que, si un juez procede de esa forma, se lleva de un tajo el principio de la ponderación de derechos, según el cual los principios constitucionales por ser prima facie, tienen que ser restringidos mediante la ley, a favor de otros principios, para poder hacer efectiva la coexistencia práctica de principios y derechos constitucionales.

Por lo tanto, si una ley restringe válidamente un derecho fundamental, dicha restricción es válida y el juez no tiene más remedio que aplicarla, a menos que con ella se aniquile por completo el núcleo esencial del derecho restringido (Infra...). Que el lector salga a los juzgados y pregunte por alguna sentencia en la que no se aplique la ley, sino que se aplique directamente la constitución. Solo en caso de tutelas, y eso excepcionalmente, hallará una aplicación directa. En los demás casos se sigue aplicando la ley. Basta agregar que la casación jamás se hace sobre juicios de moralidad y de justicia del fallo recurrido, sino sobre la base de la violación de la norma por falta de aplicación, por aplicación indebida o por interpretación errónea, es decir, es un problema 
de interpretación positiva y lingüística consagrado expresamente en el artículo 235 de la Constitución.

\section{Criticas del derecho a la Teoría de la Adjudicación Judicial}

“...Respecto a las críticas del derecho a la Teoría de la Adjudicación Judicial y a las Teorías predominantes en Colombia, los juristas Vicente Fabián Benítez Rojas y Germán Alonso González Herrera, invocando al autor del libro Duncan Kennedy como pretor, hacen un estudio crítico del derecho a la teoría de la adjudicación judicial y a las teorías jurídicas dominantes en Colombia, afirman en la introducción, que en estos cinco años han interactuado con códigos, sentencias, doctrinas y un sin número de pensamientos expresados por profesores acerca de la concepción judicial, que la mayoría de las veces nos presentaban un escenario de antagonismo y contradicción, representados por dos escuelas: el formalismo y el antiformalismo..." (Benítez \& González, 2009, 162).

Refieren asimismo que, por ejemplo, esta polémica (para la mayoría) se da en el llamado "choque de trenes" cuando se enfrentan dos perspectivas distintas del derecho, la teoría jurídica se divide en dos polos opuestos y muchas instituciones y doctrinantes son clasificados en una o en otro según la posición que asuman.

Afirman Benítez y González (2009, 163), que para esto nos valemos del jurista estadounidense Duncan Kennedy tratando de exponer que el juez en la adjudicación judicial busca reproducir un deseo: el deseo de llegar a una sentencia políticamente favorable a sus convicciones (la sentencia a la que se quiere llegar), con relativa 
independencia del campo jurídico que se estudia y para lograr ese fin recurre tanto a argumentos formalistas como antiformalistas (y argumentos mixtos) rompiendo ataduras y simples dualidades o escuelas (Formalismo y antiformalismo entendidos como ideología son destruidos por la sentencia a la que se quiere llegar).

Nuevamente esta teoría latinoamericana corrobora la real praxis que opera dentro del sistema colombiano actual, sistema penal acusatorio, en cuanto a la forma como ser llega a la toma de decisiones judiciales -aquí, adjudicación judicial- esto es para nosotros lo que en muchas ocasiones, bajo un halo de argumentos formalistas y aun tomando los argumentos antiformalistas, se rompe con el esquema que se traía de ideologías anteriores, simple y llanamente para llegar a decisiones o sentencias judiciales a las cuales se quiere arribar rompiendo esquemas, tradiciones y conceptos que se han denominado formalistas, lo cual conlleva a que ese llamado antiformalismo se convierta en una discrecionalidad arbitraria.

A modo de introducción, estos autores nos hablan de que nos han presentado un escenario de antagonismo, el formalismo y el antiformalismo, la teoría jurídica se divide en dos polos, pero el operador judicial nunca se casa en su totalidad con una $u$ otra escuela.

Con respecto a los estudios críticos del derecho, se plantea que nacen en los años setenta en los Estados Unidos como herederos del realismo norteamericano. Siendo la primera idea que tomamos de Kennedy, la siguiente: el juez proyecta primero la sentencia a la que quiere llegar (basado en múltiples factores políticos, económicos, morales, etc. y lo que cree que es justicia) y luego da forma a sus argumentos para sustentar la decisión. 
La segunda idea es que no hay una meta sistema que pueda describir la adjudicación judicial en el derecho privado, es decir, no hay escuelas.

Desde finales de la década de los treinta hasta 1991, con la expedición de una nueva Constitución, se dice que la teoría jurídica dominante en la conciencia nacional sería de nuevo el formalismo. Pero ante la evolución del constitucionalismo moderno representado en cartas de derechos más amplias, con un tribunal que los garantice, se expresó que el nuevo derecho había renacido de sus cenizas. En ese orden de ideas, gran parte de la comunidad jurídica ha encasillado a los jueces en una de dos escuelas: formalismo (usualmente se le coloca ese sello a la Corte Suprema de Justicia) y antiformalismo (a la Corte Constitucional se le ha identificado con esta corriente).

Duncan Kennedy, uno de los precursores de los estudios críticos del derecho y quien sigue a Nietzsche, en algunos aspectos, se constituye en un virus -como él mismo lo dice- dentro de las teorías dominantes. En efecto, al decir que el juez proyecta primero la sentencia a la que quiere llegar y posteriormente elabora su argumento, moldeando el campo jurídico, quiere decir que independientemente de la teoría a la cual el juez se acoja, lo que prima en últimas es "un juicio desarticulado e inconsciente".

Para César Rodríguez (cf. Benítez \& González, 2009, 163): “Kennedy sostiene que los jueces esconden deliberadamente las motivaciones reales de sus fallos bajo el manto del discurso de la aplicación mecánica del derecho, debido a que dicho discurso hace parte de la concepción dominante de la función judicial. Si se apartan de esta concepción -v.gr. confesando que la decisión de un caso concreto estuvo basada en una preferencia ideológica -son blanco seguro de la crítica de los guardianes de la tradición 
jurídica (colegas, abogados, profesores de derecho, etc.) e, incluso, pueden llegar a perder su cargo".

Al juez no le interesa usar herramientas propias de una escuela, sino que utiliza cualquier tipo de instrumento que le pueda servir para argumentar (argumento que sería el límite de la libertad que tiene el juez).

Se dice que tomó una decisión formalista o antiformalista, pero fue la sentencia a la que quería llegar lo que lo llevó a eso (no se trata de un simple eclecticismo).

Desde el punto de vista práctico, Benítez \& González (2009), citan como ejemplo dos sentencias: El primer caso es acerca de una de las características cardinales del clasicismo, es el papel trascendente que tiene la deducción, sinembargo la Corte Constitucional sigue aplicando de manera preponderante este método. Por ejemplo, en la sentencia C-573/05, se construyó en más de diez páginas la premisa mayor del silogismo (solo el Congreso expide normas de policía).

El segundo caso es la sentencia C-543 de 1992 donde se analizaba la procedencia de tutelas contra providencias judiciales. En la cual para sustentar una posición "antiformalista", los magistrados que salvan el voto, expresan que la sentencia es reflejo del formalismo. Se recurre a un evidente literalismo, que podría ser considerado formalista.

La sala de casación penal de la Corte Suprema de Justicia también ha utilizado argumentos que podrían ser calificados como antiformalistas concretamente en la sentencia del 26 de noviembre de 2003 (MP Anibal Gómez Gallego, rad. 19912), donde se estudiaba la posible existencia del delito de prevaricato por omisión. En esta 
providencia luego de haberse verificado que el aspecto objetivo de la conducta se había producido (retardo en la función del juez al no cumplir los términos), se analiza el aspecto subjetivo de la misma, es decir, si el juez se retardó en decidir de manera dolosa. No obstante, antes de iniciar un examen clásico del dolo, se dijo que la sala no podía desconocer "la desafortunada realidad que agobia a la mayoría de los despachos judiciales en el país", dada la gran cantidad de procesos y expedientes que conocen los jueces de la República, lo que hace muchas veces casi imposible físicamente cumplir los términos.

Es así como la Corte Suprema de Justicia, sala penal, antes de evaluar si el juez tenía la voluntad de retardarse y si además conocía que su conducta podría ser un delito, prefirió primero tener en cuenta la realidad judicial y además indicó que al momento de evaluar la responsabilidad penal, es indispensable tener en cuenta las circunstancias particulares del caso bajo estudio: "es necesario examinar si el juez estuvo o no en condiciones de cumplir dentro del término legal, la obligación de decidir..."

Si los argumentos de la Corte se hubiesen restringido a un estudio meramente formal, el juez habría incumplido los términos del Código de Procedimiento, sin importar "la desafortunada realidad" de la justicia colombiana y muy probablemente se habría configurado el aspecto subjetivo de la conducta: el juez conoce los términos para decidir y voluntariamente los habría desconocido ante la imposibilidad de fallar, en otras palabras, se habría dado el viejo latinismo dura lex sed lex. De este modo el propósito político o el deseo de la Corte (la sentencia a la que quería llegar), fue proteger a los jueces de la república de un posible precedente que podría afectar a muchos, si se da el 
prevaricato por omisión sin tener en cuenta la congestión judicial del país. Para lograr el anterior objetivo no era conveniente utilizar un argumento "formalista" y por esta razón recurre a uno antiformalista (Bustamante, 2006).

De las anteriores situaciones se pueden extraer varios elementos:

- El juez, sea en un sistema de derecho continental o anglosajón, goza de gran discrecionalidad al tratar de adecuar el campo jurídico, social y económico a la sentencia a la que él quiere llegar.

- En el proceso de darle forma a su razonamiento para sustentar la decisión, los argumentos pueden adquirir cierto ropaje formalista (el salvamento de voto de la sentencia C-543 por ejemplo) o antiformalista (el realismo mostrado por Tamayo y por Arrubla en la Corte Suprema de Justicia), pero no por eso se debe “etiquetar" a los jueces con su pertenencia a ciertas escuelas, cuando lo cierto es que el deseo inconsciente del juez se cristaliza en una sentencia con argumentos bastante racionales, pero a los que subyacen preferencias políticas, económicas y morales entre otras, que determinan la actuación del juez.

- De esta estructuración de nuestros jueces, lo único que se obtiene es evitar que creen o innoven al momento de elaborar la sentencia, porque de lo contrario fallarán de una u otra forma, exclusivamente por el hecho de pertenecer a otra escuela, es decir el antiformalismo y el formalismo se convierten en límites infranqueables.

Una de las principales características del derecho tradicional es que se prefieren reglas concretas que regulen los temas, por sobre los principios generales, dado que ellos, precisamente por su generalidad son susceptibles de manipulación y acomodación. 
Se restringiría demasiado la discrecionalidad del juez (y por lo tanto la sentencia a la que se quiere llegar), por tratarse de precedentes ratios y líneas jurisprudenciales muy específicas y racionalizadas a la manera de los códigos y en el evento en el que el juez se aparte de éstas, la legitimidad de su decisión sería muy relativa. (Se reprime la intención del juez, ya que se canaliza con el precedente).

El profesor Arturo Valencia Zea, al referirse a la jurisprudencia, afirma que las interpretaciones de la Corte Suprema de Justicia "suelen adquirir fuerza obligatoria semejante a la de la ley...De ahí que al lado del derecho que contienen las leyes, exista el derecho jurisprudencial..." (Benítez \& González, 2009, 170. Tomado de Valencia, Arturo, op. Cit., pag 108).

Corolario de lo anterior, la Corte Constitucional, con el propósito político que tiene, utiliza tanto herramientas "formalistas" como "antiformalistas" para lograr su cometido, por lo cual, clasificar a los jueces dentro de una u otra institución, resulta problemático.

Igual situación puede predicarse de la Corte Suprema de Justicia, con un propósito político también, pero distinto al de la Corte Constitucional, por ejemplo, con el debate sobre procedencia de tutela contra providencias judiciales, donde para argumentar su posición, puede dar la apariencia de que se es formalista o antiformalista, pero lo que se da es una fachada de argumentaciones más clásicas o más modernas (nuevo derecho).

Wolkmer (2003), en su libro "Introducción al pensamiento jurídico crítico" se propone señalar algunas líneas muy generales sobre la emergencia y la evolución de las últimas décadas, de un pensamiento crítico jurídico insurgente e interdisciplinario en el 
ámbito del derecho, dicho movimiento abarca diferentes países de la comunidad occidental, que comprende incontables concepciones epistemológicas.

Aunque se reconozca que no existe una teoría crítica jurídica general, acabada y científica, no se podrá dejar de considerar la significación del pensamiento crítico como la expresión más auténtica de la insatisfacción de grandes grupos de juristas y doctrinantes sobre la predominante formulación científica del derecho y sus formas de legitimación dogmática.

El pensamiento crítico busca descomponer o mejor, romper con la dogmática lógico-formal imperante en la cultura jurídica de un país, generando procesos de autoconciencia y transformación de la realidad social para lograr crear espacios de cambio.

"La temática estudiada privilegia a los movimientos jurídicos críticos de naturaleza filosófica desarrollada en E.E.U.U. y en algunos países de Europa Occidental y América Latina en un período de la década de los 70, 80 y comienzos de los 90, con lo cual busca despertar en la conciencia una postura militante y comprometida con el nuevo proyecto Derecho, transformándolo en instancia al servicio de la justicia, de la emancipación y de la dignificación de los seres humanos". (Wolkmer, 2003, 28).

En las últimas décadas, la trayectoria histórico-social del pensamiento jurídicofilosófico comparte entre autores y escuelas, la idea que existe una profunda crisis de valores y que es necesaria una redefinición de la racionalidad y se deben buscar, así mismo, otros fundamentos de verdad. 
En el desarrollo de la modernidad se confirman los límites y la insuficiencia de los modelos culturales, normativos e instrumentales que justifican la dimensión de la vida, la organización social y los parámetros de la cientificidad, delineados en el idealismo individual, el racionalismo liberal y el formalismo positivista, manteniendo el discurso filosófico, científico y jurídico, noobstante han visto sus sustratos cuestionados y sustituidos por patrones nuevos de referencia y legitimación.

Todos los autores, escuelas y movimientos nos aportaron un cuadro políticojurídico prácticamente uniforme, centrándose en un compromiso de carácter pedagógico de la crítica jurídica con la creación de un espacio de cambios, informado por la discusión y por la participación, generador de un derecho verdaderamente justo. Se centraron así mismo en proclamar el surgimiento de otro derecho en el contexto de América Latina y dentro de los marcos del pluralismo comunitario, participativo y democrático, que lleve implícito el reconocimiento de un nuevo proyecto ético-político emancipador, que permita el florecimiento de una nueva cultura jurídica.

Se tiene que la expectativa, al implementar el nuevo sistema penal acusatorio, era inicialmente, gestionar un control en lo referente a términos, sin embargo, al observar las diferentes estadísticas, se puede indicar que la falla no se encuentra en el volumen de procesos judiciales, sino en el sistema investigativo, lo que genera impunidad.

Aunque la ley 906 de 2004 se encuentra dentro de la medianidad de la aceptación del común, encontramos que los niveles estadísticos señalan un colapso inminente, en donde el juez no tiene la fuerza suficiente, ni la infraestructura para agilizar la administración de justicia. 
El sistema penal acusatorio, conocido como sistema adversarial, solamente se evaluará frente a si se cumplió con los objetivos trazados desde un principio, los cuales pretendían atender de manera más ágil la administración de justicia y si efectivamente se han erradicado los vicios que se venían trayendo con relación a la ley 600 .

En Colombia, conforme a los estudios realizados, se interroga si las decisiones de los jueces, a partir del derecho, podían ser un elemento importante para el desarrollo social, desde el punto de vista de la sociología del derecho; defendían la idea de que, a través de las decisiones judiciales, podían lograrse cambios sociales significativos, a partir de que estos tuvieran una independencia relativa de la burocracia, lo que en mediana forma se da, en otras ramas del poder. Otros estudios se centran en la oposición a la idea del cambio social a través del derecho.

Las cortes están sometidas a una tensión casi permanente, entre la protección eficaz de los derechos y las necesidades institucionales. Sin embargo, la tensión es más intensa en Colombia debido a la mayor brecha que existe entre un texto constitucional muy progresista y una realidad social en la cual, la violación de derechos es pan de cada día.

\section{El Derecho en América Latina}

Jorge Esquirol (2014), en su obra “Las Ficciones del Derecho Latinoamericano”, recoge una serie de estudios de derecho comparado sobre Latinoamérica. En este libro se perfilan dos grandes tradiciones de comparatismo transnacional, que proponen diferentes visiones de la evolución jurídica, por medio de sus "ficciones", las cuales responden al tipo de construcción social que sostiene a cada una de ellas. En este sentido, la 
construcción social del derecho se refiere a los argumentos, imágenes y discursos que sirven, por una parte, para legitimar el derecho, y por otra, para efectuar cambios en este.

El comparatismo clásico europeo, en sus usos en Latinoamérica, es principalmente un discurso legitimador. Confirma la pertenencia de la región al derecho europeo y a su mismo círculo de "ciencia jurídica". En cambio, el comparatismo basado en el desarrollo económico de los años sesenta y setenta, patrocinado desde Estados Unidos, es sobre todo un discurso crítico y reformador, al menos en su orientación. Ese comparatismo abre un espacio para la transformación de la cultura jurídica, de sus entidades administrativas y de sus sistemas de regulación.

“...El conocimiento predominante sobre el derecho nacional de países de Latinoamérica..., también incide directamente en el tipo de propuestas de reforma apoyadas internacionalmente, la financiación de la ayuda, los créditos intergubernamentales y los expertos extranjeros. Y no influye menos en la posición del derecho nacional en momentos cruciales, como la negociación de tratados internacionales relacionados con temas jurídicos, el reconocimiento de los sistemas de regulación nacionales por parte de organizaciones internacionales, la ejecución en otros países de sentencias de tribunales nacionales de Latinoamérica y otros aspectos...”. (Esquirol, 2014, 24, 25).

Haciendo un estudio latinoamericano en el área regional podemos encontrar varios efectos característicos, como la influencia europea, la colonización europea, los aportes económicos estadounidenses, la constante ingerencia económica de Estados Unidos para apoyar y fortalecer la justicia, especialmente en países poco desarrollados 
económicamente y por ello sometidos a compromisos de cumplimento de metas en el campo de combatir ciertos delitos en la región. Por ello, Esquirol (2014) denomina también en términos transnacionalismo jurídico y por qué no decir, en el campo penal, caso colombiano.

Es así como se llega a una mezcla de sistemas jurídicos inapropiados, contrarios a las necesidades de cada estado, por lo tanto, las legislaciones en el campo penal no corresponden a la realidad.

En Latinoamérica el transnacionalismo europeo ha sido especialmente relevante en los proyectos de derecho positivo y de teoría del derecho, durante la mayor parte del siglo XX.

Con respecto a Latinoamérica, esta clase actual de TN parece orientarse a lo largo de tres líneas principales: los sistemas jurídicos nacionales en Latinoamérica serían versiones iliberales o fracasadas del derecho moderno; las normas sociales o informales serían más representativas de la conducta real de la gente, que el derecho estatal formal, y se necesitaría una reforma jurídica basada en mejores modelos liberales, con el fin de promover el desarrollo y la democracia. De hecho, en cierta forma, no muy diferente al TN europeo, este paradigma declara ser un modo ostensiblemente apolítico para lograr el cambio jurídico, y su campo de acción es casi universal. (Esquirol, 2014, 54, 55)

Por lo general, se considera que el derecho en Latinoamérica contribuye a un menor desarrollo social, y eso cuando no se piensa que lo subdesarrollado es el propio derecho. La percepción dominante es que los países latinoamericanos que normalmente se clasifican como subdesarrollados y atrasados, carecen de un patrón de organización 
social lo suficientemente cohesionador, que permita una base mínima con la que se pueda comparar el papel de las instituciones jurídicas como parte integral de una cultura.

Desde el punto de vista del Formalismo Jurídico existe la creencia de que la cultura jurídica de toda la región se puede explicar con facilidad a partir de la influencia de un jurista europeo prominente (o tal vez, de un par de ellos), es otro ejemplo de idea fija. Es probable que la característica más destacada en tiempos modernos, sea el lugar eterno que se le ha otorgado al jurista austriaco Hans Kelsen: "La mayor influencia en la teoría latinoamericana del derecho la ejerce actualmente Hans Kelsen”, dice Kunz. Se ha argumentado que la influencia de este autor arquetípico, puede explicar la totalidad de la conciencia jurídica de la región.

"La importancia de la influencia de Kelsen se declara frecuentemente con vigor y se expone la convicción de que Kelsen es el jurista de la era contemporánea". En concreto, se le acredita a Kelsen un formalismo jurídico muy estructurado, que lo situaría como el enemigo histórico del realismo jurídico que se les enseña a los estudiantes de derecho estadounidenses. Se le asocia con una lógica jurídica independiente y estrictamente formal, lo que contrastaría con criterios discrecionales políticos más flexibles. En la lógica Kelseniana, el derecho y los operadores jurídicos encajan en una jerarquía escalonada y cerrada de normas escritas.

Otro ejemplo más de idea fija es que el derecho latinoamericano sufre del estigma permanente de su ineficacia práctica como Derecho fallido. Este se analizará a fondo, más adelante. Gran parte del trabajo académico sobre Latinoamérica asume la forma de una simple repetición o reorganización de ideas aceptadas generalmente. El lenguaje 
variará según las teorías, los problemas, los contextos y las situaciones pueden cambiar, pero el marco conceptual y las conclusiones finales a menudo se limitan a volver a lo mismo.

Otro ejemplo de idea fija, es la llamada independencia de los jueces en sus decisiones y de algunos otros funcionarios del derecho. Gran parte del análisis transnacional identifica "la falta de independencia" como una constante fallida del derecho en Latinoamérica. Un reciente artículo señala lo siguiente:

“...Muchos estudios bien conocidos sobre la independencia judicial en Latinoamérica elaboran lo que cabría llamar argumentos monolíticos y milenarios. Keith Rosenn, por ejemplo, argumenta que toda Latinoamérica sufre de una falta permanente de independencia judicial (...). Dada la proliferación de definiciones de independencia usadas por los distintos académicos, si hay alguna sorpresa en esta literatura es que todo el mundo está de acuerdo en que, sea como sea que se defina independencia, Latinoamérica no la tiene...”. (Brinks, 2005: 595-596).

Para éste autor, Independencia puede tener una multiplicidad de significados. Puede significar en un caso, independencia respecto a otras ramas del gobierno, a la política partidista, a los intereses de los litigantes o a cualquier influencia externa distinta al derecho.

La independencia parece estar relativamente clara, solo en dos sentidos. En primer lugar, como simple independencia formal, puede significar una estructura organizativa completamente autónoma, con criterios establecidos para el nombramiento permanente de sus miembros y los ascensos profesionales. En segundo lugar, el concepto de 
independencia parece relativamente claro en casos extraordinarios e improbables de total libertad institucional.

De hecho, una medida común citada como prueba de la independencia judicial es el porcentaje de casos judiciales decididos contra el Estado cuando este último es parte de los procesos.

Se puede defender la tesis creíblemente, al menos respecto a estas teorías idealizadas del derecho, que no es humanamente posible conseguir la independencia del derecho, desde el punto de vista operativo.

En todo caso, la independencia como aspiración, se propone conseguir la fidelidad, no a la ideología, a la política o a uno mismo, sino al cumplimiento estricto del imperio de la ley. En otras palabras, las decisiones y las acciones judiciales, según esta visión, deberían esforzarse por ajustarse únicamente al derecho. No obstante, no se puede negar la multiplicidad de resultados jurídicos posibles, incluso si nos limitamos a los postulados de buena fe. Estos resultados divergentes en casos concretos pueden producirse por diversas razones. Por ejemplo, pueden ser el resultado de interpretaciones alternativas e igualmente factibles de una misma norma o por jurisdicciones diferentes o leyes que se contradigan, por la relativa imposibilidad de tomar decisiones de una forma puramente neutral y objetiva, etc.

Las afirmaciones de independencia defienden el valor no ideológico, no político y no idiosincrásico del derecho. Por ello, el ejercicio de la discrecionalidad en asuntos jurídicos, de tal forma que produzca su aceptación general como actividad objetiva e 
independiente, es, en el estado actual de nuestras técnicas jurídicas, un ejercicio bastante más complejo que el de una práctica particular.

En una amplia variedad de situaciones, es inevitable que los funcionarios del sistema de justicia actúen en áreas en las que existe una discrecionalidad más o menos amplia y en las que hay que decidir entre varias posiciones, a veces en conflicto entre sí.

En el derecho latinoamericano, las reformas en el campo penal han fracasado por imitar legislaciones y procedimientos externos. La falta de estudios sociopolíticos serios y reales, acordes a las situaciones de cada país, generan falta de autonomía e independencia ideológica y resultados negativos en el debate legislativo, como es el caso de Colombia.

Además, la independencia puede ser un valor positivo cuando significa responsabilidad ante el público por las decisiones adoptadas. También puede ser positiva cuando se refiere a las influencias externas que incorporan al derecho las debidas prioridades sociales, una política estatal coordinada o simplemente una buena gestión.

Esquirol (2014), en su obra Las Ficciones del Derecho Latino Americano, en el capítulo Legalismo Latino Americano presenta una interpretación analítica en la cual cita al Jurista René David, uno de los principales faros del derecho comparado del siglo pasado. La interpretación que hace éste autor de Latinoamérica presenta un argumento sociológico que apoya el legalismo tradicional; así mismo identifica el derecho Latinoamericano como parte del derecho europeo, lo cual es una posición bastante convencional y señala: "En todos los países el derecho está en estrecha relación con 
todos los demás factores de la vida social. El derecho no podría comprenderse sin el conocimiento de la sociedad que él gobierna”. (David, 1956)

$\mathrm{Su}$ argumento es importante porque configura la aplicación usual de una rama importante de la jurisprudencia sociológica al derecho en Latinoamérica (Herget y Wallace, 1987).

A primera vista, su enfoque permite al menos dos posibilidades obvias: bien una crítica de la brecha entre el derecho y la sociedad, (Karst y Rosenn, 1975), o bien una defensa de la congruencia entre el derecho y la sociedad. Es decir, el análisis basado en la sociedad puede ser la base de la crítica y también de la legitimación del derecho: no tiene ninguna orientación política predeterminada.

En contra del idealismo, el Jurista René David (1956), evita afirmar que el derecho latinoamericano sea una simple imitación del derecho europeo. La originalidad del derecho latinoamericano, según David, es la variedad de fuentes europeas que lo forman. David recuerda la letanía familiar de modelos jurídicos extranjeros que se supone que copia el derecho latinoamericano: el francés, el español. El portugués, el italiano y el alemán, y también el derecho público estadounidense. David aclara:

"El derecho latinoamericano es original en un primer sentido, y es interesante estudiarlo, porque no ha adoptado en su totalidad ni el derecho francés, ni el derecho español, ni el derecho portugués, ni el derecho italiano, ni el derecho alemán. Ha hecho el esfuerzo por tomar lo mejor de cada uno de esos derechos, lo más satisfactorio desde un punto de vista teórico, pero también desde el práctico; la forma en la que (esos países) han combinado y reconciliado los principios de los diversos derechos constituye 
un experimento al que merece la pena prestarle interés y confiere a ese derecho una certidumbre con respecto a su originalidad" (David, 1956, 121)

La ideología de los juristas latinoamericanos coincide con la ideología de la familia jurídica occidental o europea y más específicamente, con la de la sociedad europea. Expresado de manera más cruda, David (1956) se enfrenta a un conflicto entre la política y la teoría del derecho en América Latina. En Europa, ambos proyectos se alinean en torno a una concepción democratizadora del derecho y una base para reconstruir la ciencia jurídica. Sin embargo, en Latinoamérica se considera que el carácter de la sociedad amenaza el mantenimiento de un régimen jurídico separado de la política.

No comparto la tesis del autor en su totalidad. Pretender aislar el derecho latinoamericano y europeo del colombiano, en determinadas formas e ideales jurídicos no es viable del todo, pues no puede dejarse de lado el derecho comparado, y el derecho regional latinoamericano, aunque esto no implica que Colombia pierda su autonomía. No se puede desconocer los principios universales del derecho penal positivo o de los derechos fundamentales universales.

En resumen, preservar el imperio de la ley es una justificación para resistirse a las reclamaciones de las sociedades latinoamericanas. Y no es menos irónico que sean las sociedades latinoamericanas las que luego sirvan en este tipo de análisis para explicar los fracasos del derecho y la democracia.

Esquirol (2014) plantea que el jurista René David intenta justificar la suficiencia y la imparcialidad del derecho basada en la realidad social y que la jurisprudencia y la doctrina son fuentes del derecho. Sin embargo, a nivel de crítica preciso que no es 
justificar el positivismo ante la realidad social, sino crear normas de acuerdo a la necesidad social y cultural de un estado sin llegar al populismo legislativo de oportunidad. Asimismo, la jurisprudencia no puede ser sólo la suerte del derecho, del momento y del caso, sino la evolución de teorías jurídicas, pues las decisiones no pueden ser estáticas y sometidas a una única interpretación aplicada a casos diferentes.

El autor describe el positivismo a partir de las mismas consideraciones que el derecho natural. La pretensión central del positivismo es que todo el derecho se contiene en códigos y en la legislación. El juez no crea nuevo derecho, sino que, en lugar de eso, lo único que necesita es aplicar las normas dadas. Los silencios o las contradicciones aparentes se resolverán mediante el razonamiento lógico y analógico.

Se recuerda a Geny por su método empírico sociológico del derecho. Aquí, de manera característica, este defiende la imposibilidad de que los códigos o los actos legales positivos, contengan todo el derecho. Lo que se denuncia es que la codificación no puede anticipar todos los conflictos jurídicos previsibles; por consiguiente, el derecho contiene vacíos. Cuando el código contiene vacíos, las decisiones jurídicas deben proceder de alguna fuente alternativa. Si no se aborda de alguna forma, esa fuente puede equivaler a la arbitrariedad judicial, lo que sería una ruptura en la teoría de la toma legítima de decisiones.

René David se refiere a Edouard Lambert, como uno de los principales participantes en el histórico Congreso de París de 1900 y quien expresa claramente la crítica externa a la autosuficiencia, al afirmar el fundamento histórico de la creación del derecho en la jurisprudencia. 
Como un hecho importante, Esquirol (2014), refiere que René David apoya la posición de que además de los códigos, la jurisprudencia es una fuente bien arraigada de derecho en Francia; así mismo señala que éste declara sin ambigüedades:

"Las fórmulas en cuestión, que niegan a la jurisprudencia y a la doctrina en particular la cualidad de fuentes del derecho francés, no engañan en realidad a nadie en Francia. Sabemos que la legislación no lo puede prever todo, y no lo ha previsto. Sabemos que el orden legal, a diferencia del jurídico, tiene lagunas, en Francia y en todos los otros países. Conocemos la importancia de la función que ejercen la jurisprudencia y la doctrina en precisar el sentido de las fórmulas legales y también las lagunas de nuestras leyes, incluso en nuestra técnica jurídica se invoca un texto más o menos extraño al litigio para justificar la solución propuesta" (David cf Esquirol, 2014, 140, 141).

Sobre este punto lo que señala Esquirol en el entendido de ser la jurisprudencia una fuente seria y arraigada en los países, para dirimir los conceptos jurídicos y más para llenar las lagunas que emergen de las normas; hasta el punto de afirmar que la jurisprudencia en Francia no admite error ni engaño a la solución de los conflictos judiciales. Cierto es para nosotros que, si bien el comienzo de nuestra historia jurídica y hace no muchos años, la jurisprudencia cumplía ese mismo fin y se le amparaba bajo esa sapiencia inmutable. Para la realidad actual, nuestra jurisprudencia, por el contrario, es ambigua y no unísona, frente a casos y presupuestos generales, por el contrario, ha sido mutante de una época para acá, aún frente a los precedentes constitucionales. 
Al negar los vacíos en el derecho y el papel de los jueces como creadores de derecho, el positivismo frustra la posibilidad de una reforma jurídica ilustrada. Sin embargo, mostrar la falta de validez del positivismo implica reconocer los poderes de los jueces para crear derecho y la insuficiencia de los códigos. La responsabilidad social de los jueces se aborda después en las propuestas de René David (1956) sobre el derecho comparado.

En la vida moderna, el derecho no es una ciencia pasiva, estática; evoluciona con las necesidades y problemáticas sociales producto de las interacciones humanas, de acuerdo a los avances y/ retrocesos de cada estado.

Para resumir las ideas de este apartado de David (1956), cabe decir que el autor adopta la concepción sociohistórica del derecho; es decir, la teoría de que el derecho se relaciona con la trayectoria histórica de las sociedades reales. Al rechazar las teorías del derecho natural, contempla el derecho como algo dependiente de la sociedad.

Es fundamental desarrollar una legislación de derecho positivo para cada Estado, de carácter material, de acuerdo a sus necesidades, y que este derecho positivo no se convierta en una postura ideológica contraria a los fines de la justicia. El derecho material debe recoger los ideales sociales y económicos de todos los estamentos y grupos de un Estado.

David (1956) en su primer tratado de derecho comparado, enumera los factores identificados por Montesquieu como el espíritu de las leyes:

"Las leyes deben ser de tal manera adecuadas al pueblo para el que se hacen que es una gran casualidad el que las de una nación puedan convenir a otra [...] Las leyes 
deben estar en relación con la geografía física del país; con el clima helado, caluroso o templado; con el género de vida del pueblo, agrícola, cazador o ganadero; deben estar de acuerdo con el grado de libertad que puede sufrir la constitución; con la religión de sus habitantes, sus inclinaciones, sus riquezas su número, su comercio, sus costumbres, sus maneras de vivir [...] En todos estos aspectos es preciso considerarlas [...] Estas relaciones forman en conjunto lo que se llama el espíritu de las leyes”.(p. 152)

El Jurista Jorge L. Esquirol (2014) narra "La Ficción de la ausencia del derecho" en Latinoamérica que es comúnmente objeto de una crítica sistémica por los comentaristas estadounidenses. Los sistemas jurídicos nacionales de la región, marcada por el subdesarrollo y la corrupción, se consideran parte de los muchos problemas de esta y no la solución a ellos. Como resultado, numerosas propuestas de reforma defienden la transformación y la internacionalización de dominios jurídicos tradicionalmente nacionales.

En los años anteriores, y por qué no, actualmente, varios países de la región latinoamericana han sido motivo de reformas jurídicas, de acuerdo a la ideología de derecha, de centro, de izquierda, o de cualquier otra, con un propósito más político que social, sin ver las necesidades sociales. Esta situación ha derivado en influencias graves y resultados negativos en el campo de la criminología y el derecho penal, y dificultades en la aplicación de normas de la legislación penal, generando impunidad entre diversos gobiernos.

Finalmente, la idea del derecho fallido reduce el prestigio, el estatus y la credibilidad de los latinoamericanos en las relaciones jurídicas hemisféricas y 
transnacionales. Bajo el nombre de falla funcional se encuentran diversas descripciones, se habla desde el colapso generalizado del sistema jurídico, hasta de una falta de niveles adecuados de aplicación coercitiva del derecho; de la ineficiencia en los procedimientos jurídicos o en las transacciones que realizan los ciudadanos; del insuficiente entrenamiento de los operadores del derecho (en especial de los servidores públicos) y de varios otros aspectos que impactan de manera negativa el desempeño general del sistema.

De esta manera, la imagen de fracaso jurídico resulta amplificada y proyectada de manera muy fuerte en Latinoamérica. En primer lugar, estas críticas son características generalmente aceptadas en todos los derechos modernos: la caducidad de muchas doctrinas e instituciones jurídicas frente a nuevas necesidades sociales fue teorizada por el juez Holmes (para el caso de los Estados Unidos); la desconexión entre derecho y sociedad fue advertida por teóricos tanto hitoricistas como sociológicos; los realistas jurídicos criticaron el excesivo formalismo del derecho; los excesos de los jueces fueron claramente denunciados desde la perspectiva del legal process: la distancia entre el derecho formal y el derecho en acción fue subrayada por los teóricos del movimiento de derecho y sociedad. En segundo lugar, es necesario notar que estas críticas se hicieron originalmente, no contra el sistema jurídico en su conjunto, sino contra decisiones judiciales, leyes o prácticas institucionales concretas que en algún momento histórico generaron polémica y discusión. Mediante el concepto de "[des]Estado" de derecho se pretende lograr una resolución satisfactoria de la tensión entre objetividad y subjetividad en el proceso de toma de decisiones jurídicas. Los teóricos liberales del derecho se han 
preocupado siempre por evitar que el derecho sea tan solo el resultado de la discreción subjetiva de sus operadores.

La imagen del Estado de derecho (de la existencia del rule of law), por lo tanto, resulta ser el producto de una combinación de factores, entre los que se destacan: la existencia de consensos políticos internos significativos (con los que se evita la volatilidad institucional), altos niveles de control social y aplicación coercitiva del derecho, la existencia de amplios recursos informativos, la existencia de normas sociales paralelas a las estatales que las refuerzan y, para finalizar, un grupo muy dedicado de académicos jurídicos y políticos que afirmen que todo esto en la realidad es así.

Finalmente, Esquirol (2014) hace una crítica al procedimiento penal y esfuerzos para su reforma indicando que el procedimiento penal es otra de las preocupaciones centrales de los neo desarrollistas.

Y continúa, diciendo que el procedimiento penal que existía hasta antes de las reformas es usualmente vinculado con el autoritarismo político, con el abuso a los derechos humanos, con altos niveles de impunidad, con bajos niveles de aplicación coercitiva del derecho y, finalmente, con ineficiencia. Los objetivos que se busca lograr con las reformas van desde la prioridad que los chilenos dieron a la protección de los derechos ciudadanos, hasta la urgencia de los colombianos en lograr la reducción de las tasas de criminalidad. En cualquiera de estos escenarios y para impulsar las reformas, los neodesarrollistas empezaron por advertir que el derecho penal de Latinoamérica no satisfacía los requisitos del rule of law. He aquí un ejemplo: 
“En nuestros sistemas, la rutina ha reemplazado el examen del caso concreto, y el formalismo ha reemplazado a la verdad. Cada vez se vuelve más visible el gran abismo que existe entre los principios consagrados en la Constitución y en la ley, y las prácticas reales de la administración de justicia. Muchas reformas penales han fracasado o están en el proceso de sucumbir, precisamente porque la práctica ordinaria se ha impuesto al texto de la ley y a los principios que la inspiran” (Esquirol, 2014, 344).

Resulta importante hacer notar que algunos analistas ya están criticando los nuevos procedimientos acusatorios establecidos en Colombia en 1991, con exactamente los mismos términos de la retórica del derecho fallido que se utilizaron con anterioridad para permitir la reforma.

A modo de conclusión, Esquirol afirma que la reforma del derecho y de las instituciones jurídicas en Latinoamérica bajo la esfera de influencia de los Estados Unidos se ha promovido de una manera más bien particular. Con el propósito de argumentar a favor de nuevas direcciones de política pública, las prácticas, normas e instituciones actualmente existentes han sido rutinariamente criticadas. Se presentan como instituciones poco viables y finalmente terminan por calificarse como fallidas o fracasadas. El conjunto de imágenes discursivas que son típicamente utilizadas incluyen la obsolescencia, la inflexibilidad, la irrelevancia cultural, la ineficiencia económica y la alta corrupción. Todas estas características son también comunes a todos los sistemas jurídicos del mundo, por lo menos en algún grado. 


\section{La cara jurídica de la política social.}

Courtis (2009), en su obra "Ecos cercanos. Escritos sobre derechos humanos y justicia" trata el proceso actual del nuevo constitucionalismo y de los derechos humanos, especialmente en Latinoamérica, donde comenzó con reformas constitucionales en Brasil, seguido por Colombia, Perú, Argentina, Venezuela, Bolivia y Ecuador. El uso cada vez mayor del derecho comparado evidencia una internacionalización del derecho constitucional contemporáneo. Otro aspecto nuevo que allí se trata es la relación entre derecho y distribución de recursos económicos, es decir sobre los derechos sociales.

Aquí veremos los derechos sociales relativamente nuevos en el ámbito jurídico y su inclusión dentro de los ordenamientos jurídicos, especialmente de los países de América Latina. Vemos, además, que hoy se requiere integrar los pactos internacionales sobre derechos humanos a los ordenamientos locales.

\section{Derechos sociales e instrumentos internacionales de derechos humanos}

Para la aplicabilidad y efectividad de los derechos sociales hay que tener en cuenta principalmente tres aspectos a saber: la interpretación de las normas sobre el tema, la aplicación de dichas normas y las garantías que aseguren su efectividad. En todos los casos, tanto los tratados y los organismos internacionales, como los documentos generados por estos últimos sobre el tema, son fundamento esencial para la aplicabilidad de los derechos sociales.

Tres discusiones sobre derechos sociales. Comentarios críticos a los trabajos de tres tratadistas: 
- Guastini: Distinciones dudosas: el autor distingue entre "verdaderos derechos" y "derechos sobre el papel", y dice que en la mayoría de los casos los derechos sociales son derechos "sobre el papel", pues no comportan necesariamente los mecanismos para garantizar su aplicación, ya que el legislador no está obligado a establecer los medios para ello (Courtis, 2009, 132, 133).

- La Porta: Los Derechos sociales ante los jueces, se refiere al tema de la protección de los derechos sociales. La Porta habla del caso en que haya ausencia de norma y del servicio necesario para satisfacer el derecho; considera que la sentencia judicial que declare la omisión y obligue a legislar sería poco efectiva, minando así la legitimidad de la actuación judicial y desplazando al principio democrático al asumir decisiones de política económica. El autor observa que la hipótesis es remota, pues hoy la mayoría de los estados de Europa y América Latina ya han legislado al respecto. (Courtis, 2009, 138, 139).

- Atria: La fuga frente a los derechos sociales, Propone la incompatibilidad entre los derechos sociales y los derechos subjetivos, porque de otra manera destruirían cualquier proyecto socialista basado en la reciprocidad y la solidaridad. Propone así, que los derechos sociales solo tienen sentido político y no un sentido jurídico. El autor refuta este criterio, al decir que los derechos sociales, entonces, solo tendrían un valor de reclamo lícito, siendo derechos que buscan satisfacer el acceso a bienes primarios o a la satisfacción de necesidades básicas. (Courtis, 2009, 146, 147).

En cuanto a la Justicia y Política Constitucional, el autor describe que, en su carácter de instituciones públicas, los tribunales de justicia cumplen un innegable papel 
político en la configuración de las sociedades en las que vivimos. Aunque parte de la teoría jurídico-política dominante en las facultades de derecho se haya empecinado en negar este papel, y pese a que la propia retórica judicial presente su actividad como técnica o apolítica, la labor de los tribunales determina, directa o indirecta, consciente o inconsciente, explícita o silenciosamente, por acción o por inacción, importantes aspectos de la vida económica, política y social de un país. Las decisiones de los tribunales conforman de manera importante las relaciones entre particulares, entre los particulares y las instituciones estatales y entre las distintas instituciones estatales y tienen fuerte proyección sobre el funcionamiento de la economía, sobre la esfera de autonomía de las personas y sobre el alcance de la acción del Estado. (Courtis, 2009: 407).

\section{El papel político del poder judicial}

Dentro de los estudios sobre derechos humanos y justicia, Courtis (2009: 409) en este tema refiere que uno de los ejes de análisis más extendidos acerca del papel político del poder judicial quizás sea el del grado de intervención o protagonismo de los tribunales en la adopción de las decisiones políticas de una comunidad. Refiere el autor también que esta discusión ha monopolizado gran parte de los desarrollos de la teoría constitucional estadounidense, al menos de los años sesenta del pasado siglo, ha planteado en términos de un debate entre activismo y autorrestricción (o autolimitación) judicial.

Tendencialmente, podría decirse que el foco de atención de esta disputa es la medida en que los tribunales acompañan con su aplicación las decisiones políticas de los demás poderes, o bien adoptan un rumbo decididamente distinto, apartándose del criterio 
de otras ramas del gobierno. Sinembargo el uso del término tiene a veces otras implicaciones. Dado que los términos del debate no siempre resultan claros y que estas categorías han sido empleadas de modo errático en el debate jurídico latinoamericano, cabe detenerse en un intento de caracterización de estas ideas. Uno de los mayores análisis sobre estas categorías ha sido propuesto por Bradley C. Cannon, autor de uno de los intentos más completos de sistematización de las definiciones de activismo y autorrestricción.

El autor Cannon, (cf Courtis, 2009: 411) sugiere seis ejes a saber:

- Carácter mayoritario, es decir si las decisiones políticas adoptadas a través de procedimientos democráticos son revocadas judicialmente.

- Estabilidad interpretativa, es decir, grado en que se modifican decisiones, doctrinas o interpretaciones previas de los tribunales.

- Fidelidad interpretativa, es decir, si las disposiciones legales son interpretadas en un sentido contrario al de sus autores o al claro significado del lenguaje en el que están expresadas.

- Distinción entre decisiones sobre el contenido de una política y decisiones sobre las reglas del procedimiento democrático, es decir si las decisiones judiciales elaboran o no políticas sustantivas o se ocupan solo de la preservación de las reglas del procedimiento democrático.

- Especificidad de la política establecida, es decir, el grado en el que el tribunal decide los detalles de la política establecida por una sentencia, en lugar de dejar la 
regulación de esos detalles librada a la discrecionalidad de otros organismos gubernamentales.

- Existencia de una autoridad reguladora alternativa, es decir, si la autoridad judicial reemplaza la consideración del mismo problema por otro organismo gubernamental.

El autor sugiere, para casi todos los ejes una graduación tripartita: “...Muy activista", "moderadamente activista" y "autorrestringido" para categorizar las decisiones. Puede suceder, por ejemplo, que una decisión califique como "muy activista" en una dimensión, y como "autorrestringida” en otras. Un caso típico, por ejemplo, es el del cambio de jurisprudencia de un tribunal que vuelve a considerar constitucional una norma que un precedente anterior había declarado inconstitucional..." (Cannon cf Courtis, 2009: 411).

Sobre este aspecto el autor refiere, dejando la inquietud, vaya si lo sabremos en América Latina y su ausencia, sea porque no existe un régimen democrático, sea porque, pese a la vigencia formal de un sistema democrático, la realidad se aleja en forma ostensible del ideal normativo. Asimismo, refiere, es necesario señalar que Cannon (cf Courtis, 2009: 411) limita su propio análisis a la actividad de la Corte Suprema estadounidense, donde el control judicial de constitucionalidad tiene un peso primordial.

En otras instancias sin embargo la posición del poder judicial frente a los actos de otros poderes se expresa principalmente a través de otras vías: la declaración de ilicitud de actos estatales, persecución penal, condena de funcionarios estatales, acciones de amparo, tutela y demás. 
El autor Cannon (cf Courtis, 2009: 411) no plantea una experiencia latinoamericana y de algunos países periféricos, y que corresponde al grado de apego de los tribunales a las normas procesales que los vinculan. Un aspecto notorio a través del cual se expresa el activismo de los jueces, es la extremada flexibilización de las normas procesales, a efectos de salvar limitaciones o constricciones formales y poder entender en los casos que concitan su interés. Alguien podría decir que se trata de un caso específico de bajo grado de fidelidad interpretativa de las normas procesales.

Se refiere, en resumen, al creer que las siguientes dimensiones ofrecen un buen marco referencial para situar una decisión judicial dentro de un abanico que va desde la autolimitación judicial más deferente hasta el activismo judicial más frontal:

- Confirmación o contestación de los actos de otros poderes.

- Estabilidad interpretativa.

- Fidelidad interpretativa.

- Decisión sobre el contenido/decisión sobre el procedimiento.

- Apego a las vinculaciones procesales.

Analicemos los planteamientos sobre el andamiaje teórico de la autorrestricción judicial, que hace Courtis (2009: 416): “Cuanto mayor sea la confirmación de los actos de otros poderes, la estabilidad y fidelidad interpretativa, la restricción de las decisiones a cuestiones de procedimiento y el apego a las vinculaciones procesales, más autorrestringida será la actividad de un tribunal. La actitud opuesta merecerá la calificación de activista". 
Se puede señalar, respecto a la actividad judicial de los tribunales, un sentido de incapacidad para llevar a cabo labores en virtud del reemplazo de planteamientos y decisiones de órganos del Estado.

Se observa una autolimitación judicial en las decisiones de los jueces y en el cambio y evolución de conceptos y criterios jurídicos, manteniendo por ello una consistencia en las decisiones bajo el apego normativo, basado en la tradición del concepto de la simple norma. Parece que este activismo judicial se basa solamente en mantener y respetar estas decisiones superiores y/o políticas sin tener criterios y valoraciones propias, conviertiéndose en pasividad las decisiones de los jueces. De la misma manera, se omiten y/o desconocen las normas de la Constitución, como único instituto del Derecho Constitucional, y los jueces terminan legislando, tal y como lo expresa Courtis (2009).

Me pregunto si el activismo judicial positivo y las modificaciones jurisprudenciales deben ser estudiadas solamente por la ocurrencia de un hecho, la actividad política, la propuesta de un gobierno, por el rechazo social ante un caso, por razones meramente formales o por cambios en la composición de funcionarios de un tribunal; pues ello dependería de una labor política o de oportunidad en su momento.

Lo anterior genera costos económicos para el Estado y por supuesto pérdida de recursos económicos. En Colombia, por ejemplo, el presupuesto para desarrollar estudios en el campo del Derecho Penal es mínimo, como se observa en el cuadro estadístico obtenido del Consejo Superior de la Judicatura (Anexo 1). 
Toda actuación judicial, activa o pasiva, significa un posicionamiento político, y que los tribunales moldean ese posicionamiento a través de herramientas teóricas y técnicas de muy diversa naturaleza. La consideración de algunos aspectos ligados con los problemas de legitimidad política de la actuación judicial. Algunos de estos temas ya han aparecido como argumentos justificatorios, bien de autorrestricción, bien de un papel activo de los tribunales. Existen otras variables de análisis político (Courtis, 2009).

La primera cuestión que resulta importante plantear es que la pregunta por la legitimidad de la actuación judicial no puede responderse en abstracto, tomando en consideración una o dos variables normativas, como el lugar de los tribunales en una "teoría pura" de la democracia o el origen no electivo de los jueces. La pregunta por la legitimidad requiere información empírica sobre el funcionamiento del sistema político y el conocimiento concreto del contexto histórico en el cual se desempeñan los jueces. En este sentido, el análisis de la legitimidad de la actuación judicial supone la necesaria comparación con el análisis de la legitimidad de la actuación de los demás poderes.

\section{Política criminal moderna}

Hassemer (2003), en su libro “Crítica al derecho penal de hoy”, comienza por definir la violencia, para luego ubicarla dentro del contexto social; en su capítulo II, el destino de los derechos del ciudadano en el derecho penal "eficiente", punto 1, titulado: La violencia omnipresente.

De acuerdo con la definición de Hassemer $(2003,49)$, "la violencia es un componente de nuestra experiencia cotidiana, lo que se modifica son las formas y la intensidad de esta, la disposición a aceptarla y las probabilidades de convertirse en 
víctima o también en autor de actos de violencia. Lo que hoy se modifica es la percepción que tenemos de la violencia y la actitud que tomamos frente a ella".

Los fenómenos de violencia ocupan nuestra capacidad de percepción social y cultural con una intensidad mayor que en épocas anteriores y su transmisión hacia nosotros se produce con más tendencia a comunicar dicha violencia que a ser concreta.

Violencia, riesgo y amenaza, constituyen hoy fenómenos centrales de la percepción social. La seguridad ciudadana hace su carrera como bien jurídico. Siendo el crimen organizado, la tercera amenaza después del terrorismo y el tráfico de estupefacientes.

La sociedad amenazada, necesita la Carta Magna como arsenal de lucha efectiva contra el delito y represión de la violencia, visión ésta que es anacrónica.

La tradición de la modernidad fundamentada en los derechos del hombre (La Ilustración) y del ciudadano como pilares del derecho penal y procesal penal y que admite al delincuente como socio en el contrato social.

La criminología, finalmente, descubre una estrecha relación entre delito y estructura social y se comenzaba a tener en cuenta el medio, la historia vital, la familia, etc. que rodearon al autor de la violencia, como base para una política criminal a largo plazo y bien pensada.

La criminología ha demostrado con creciente claridad que una política que quiera tratar adecuadamente la violencia omnipresente, no puede simplificar ni dramatizar su objeto, sino que debe dejarlo en su complejidad, a largo plazo, este objeto no puede ser manejado con fuerza y represión. 
En el capítulo II, El derecho penal eficiente, Hassemer $(2003,56)$ nos expresa su idea de que "el derecho penal, incluido el derecho procesal penal, es el destinatario de las exigencias de una opinión pública amenazada por la violencia, de él se espera una ayuda efectiva y la garantía de la seguridad ciudadana".

Según Hassemer (2003), las formas de represión son las penas patrimoniales para traficantes de drogas, un tipo penal contra el lavado de dinero, utilización de hombresenlace, etcétera, pero faltan aquellos instrumentos de manejo que caracterizan actualmente a un derecho penal eficiente, es decir, que aparece junto al derecho penal de cuello azul de represión de la violencia, un derecho penal de cuello blanco del manejo social.

La política criminal moderna opera con la nueva criminalización y agravamiento de las penas. Se concentra en los tipos y amenazas penales y no en las consecuencias del derecho penal.

La política criminal moderna ocupa los campos que hoy constituyen centros de riesgo en la percepción pública: medio ambiente, economía, impuestos, drogas, terrorismo, procesamiento automático de datos y los bienes jurídicos clásicos del individuo, vida, salud, libertad, etc.

Esta política tiene como fundamento la idea de que el derecho penal es un instrumento normativamente aceptable y relativamente efectivo de conducción y contra conducción, un medio más de política interna.

El derecho penal, afirma Hassemer (2003, 60), "no puede cumplir con las funciones que se le atribuyen de represión y conducción eficiente de la violencia, sino 
con la decisión de relajar la fuerza de estos principios: reducir al mínimo los presupuestos de la punibilidad mediante la utilización de los delitos de peligro abstracto, facilitar los presupuestos de la imputación o agravar los medios de coacción. La intensidad con que estamos amenazados será discutida por tiempo indefinido entre expertos y ciudadanos. La percepción de la violencia es un fenómeno político y comunicativo, se ganaría mucho si esta noción se difundiera, pues sería más difícil hacer política mediante la dramatización de la violencia”.

El agravamiento del instrumental del derecho penal no siempre mejora su idoneidad para la solución de los problemas. Finalmente, hay que preguntarse si un derecho penal disponible y políticamente funcionariado, aún puede conservar el lugar que debe tener dentro del sistema total de control social.

En este aparte se tratará de las definiciones y de lo que es un proceso penal de tendencia acusatorio, adversarial, haciendo aclaraciones conceptuales de algunas doctrinas avanzadas sobre el sistema penal acusatorio en Europa; especialmente en: España, Norte América y Colombia.

Asimismo, planteamos un interrogante sobre la necesidad de conocer la cultura jurídica francesa y de Estados Unidos, así como el Common Law. Hablaremos de las perspectivas del Common Law para la legislación colombiana. Para finalizar trataremos los objetivos del rol de jueces y magistrados en el Sistema Penal Acusatorio Colombiano.

Existen diferentes doctrinas sobre el término acusatorio, especialmente en Europa y en América Latina se habla de principio acusatorio, un principio acusatorio sin apellidos, es decir del acusatorio puro, como eje de la definitiva reforma del proceso 
penal, como lo dice Gómez (2012) en su obra El Proceso Adversarial, una crítica constructiva sobre el llamado sistema acusatorio. Refiere el autor que esto es un poco ingenuo, pues no va a depender solo de eso, ni muchísimo menos, que se pondrá para siempre a la cabeza de aquellos países que tienen en sus leyes procesales penales una prueba y manifestación de verdadera democracia, de verdadera libertad. Y en realidad no sabemos muy bien qué es el principio acusatorio.

Se puede establecer que el derecho penal se aplica por medio de un proceso y que no solamente puede ser acusatorio, pues podría ser el llamado proceso inquisitivo, ya que este último es carente de garantías propias del proceso.

Montero Aroca sostiene que una cosa fue en el pasado el derecho penal, que se aplicaba por medios no procesales (el llamado sistema inquisitivo que no era un proceso).

Principio acusatorio podemos decir es aquel encargado de la imparcialidad del juzgador y por ello el proceso acusatorio no puede existir sin acusación. De igual forma que no quepa condena por hechos distintos de la acusación y que el juez no pueda tener facultades de dirección material del proceso.

En Estados Unidos si bien la jurisprudencia y la doctrina suelen mencionar los términos proceso adversarial, o procedimiento acusatorio no se refieren en lo absoluto o casi nunca a principio acusatorio. Lo importante para esta doctrina deduzco que es el sistema o el proceso, no el principio. Se contrapone claramente al sistema inquisitivo europeo, el sistema adversarial norteamericano, afirmando que el proceso penal de Estaos Unidos es acusatorio, jugando con los conceptos de sistema adversarial y proceso acusatorio; el sistema de proceder criminalmente es adversarial, y el proceso que dentro 
de este sistema sirve para imponer las penas es acusatorio. Ambos términos, adversarial y acusatorio, se complementan respectivamente pero no significan lo mismo. Para los autores y alguna doctrina, adversarial significa que son las partes las que tienen la responsabilidad de aportar los hechos y sus pruebas al proceso, mientras que acusatorio significa que son las partes las que tienen la responsabilidad de convencer al juzgador.

En Estados Unidos no es principio acusatorio, sino proceso legalmente debido (“Due Process of Law"); en Estados Unidos no se habla de principio acusatorio, podría ser porque no hace falta, porque no es necesario, pues es obvio que hablar de acusatorio es hablar de proceso debido (Gómez, 2012, 28).

En el proceso penal federal norteamericano es necesario hacer una reflexión sobre la historia y sus antecedentes, sus instituciones políticas y la evolución económica como aspectos no jurídicos pero que tienen una relevancia significante.

Ha sido relevante para los Estados Unidos la formación política de Norteamérica, las razas, ideologías y religiones, el aspecto geopolítico y el inmenso potencial económico, este último implica en principio que, si en un país se puede asumir el costo económico de una reforma legal, por profunda y amplia que sea, da muchas posibilidades de desarrollo al sistema.

Importante referir el siguiente caso norteamericano, que ocurrió con la presidencia del juez más importante que ha tenido nunca los Estados Unidos, según opinión común, el Chief Justice Jhon Marshall, sentenció en 1803, algo tremendo en esa época, que los jueces tenían la facultad de controlar la constitucionalidad de las leyes y que, por tanto, son los jueces quienes garantizan que la ley ordinaria se corresponde con lo dispuesto en 
la Constitución, caso Marbury vs. Madison (Gómez, 2012: 41), no solo estaba construyendo el pilar más importante del poder judicial que un estado fuerte necesita, capaz de controlar el poder legislativo en aras del principio de libertad, sino que también estaba contribuyendo sin saberlo, a la construcción de los tribunales constitucionales en todas las democracias. Hizo historia, con H mayúscula (Gómez, 2012: 45).

El sistema adversarial representa además un valor superior a cualquier otro por su consideración de la dignidad de las personas, lo que lleva a que atacante y atacado y acusado, sean tratados en un proceso como iguales. Y el abogado de la defensa debe tener un papel más activo en este sistema que en cualquier otro, por ello el acusado puede defenderse a sí mismo como puede interpretarse dentro de un sistema adversarial.

¿Cuál es la razón para interesarse por el derecho de un país extranjero? Será la mejor pregunta para abordar este tema de juzgar en Estados Unidos y en Francia y que nos ubica luego en el Common Law. Puede ser la necesidad, puede ser el conocer otras legislaciones, conocer las normas internacionales, implica también conocer la protección de derechos fundamentales de la persona humana, los textos jurídicos, las constituciones nacionales de otros estados, las realidades de los tribunales tanto nacionales como internacionales, las decisiones de los jueces de diferentes países, las problemáticas económicas, las tecnologías modernas, e inclusive el terrorismo.

Esta es una de las razones por las cuales los jueces de un determinado país conectan y aprenden aspectos jurídicos creados por sus colegas extranjeros. Pues el estudio de otros sistemas jurídicos permite comprender mejor el sistema propio o interno del país y por ello lo que puede ser, lo que debe ser y lo que podría convertirse o hacerse. 
Estas comparaciones de los asuntos y soluciones jurídicas de otros países se consideran útiles. La Corte Suprema de Estados Unidos, por ejemplo, que resuelve un hecho sobre un derecho fundamental; la Corte Europea de los derechos del Hombre, que resuelve sobre una protección jurídica fundamental. El estudio minucioso y la comparación profunda de sistemas jurídicos se hacen entonces cada día más necesarios, como un ejemplo vemos los recientes esfuerzos de las cortes penales internacionales para crear un procedimiento penal común. Como lo establecen Garapon y Papadopoulos (2010) en el prefacio de su obra. ¿Esto se inspira en los sistemas inquisitivos que encontramos en los países del Common Law? O, por el contrario ¿será el fruto de una combinación de los dos? Una integración como esta requiere juristas capaces de comprender no solo uno de esos sistemas sino ambos, que presentan diferencias importantes.

Al interrogante de si se habla de sistemas inquisitivos en el Common Law por parte de Garapón y Papadopoulos, podría entenderse que en la cultura del Common Law, sobre los siglos XVIII, XIX de acuerdo con las investigaciones o proceso penal que se adelantaba, eran de modo muy inquisitivo y los procesos consistían en una clase de encuesta fuertemente marcada por tratamientos inquisitorios, conducida por magistrados y además los abogados raramente apoyaban la acusación y los abogados de la defensa no eran admitidos dentro del proceso criminal, esto antes de 1.837. Claro está que la cultura del Common Law ha venido evolucionando, pero si necesariamente estos autores hablan de un sistema inquisitivo, haciendo referencia a John Langbein, The Origins of Adversary 
Criminal Justice, Oxford, Oxford University Press, 2002. (Garapón y Papadopoulos, Juzgar en Estados Unidos y en Francia, 9).

La comparación profunda de los sistemas se extiende también en el derecho constitucional, por ello se llevan a cabo diversas conferencias donde participan jueces de diferentes jurisdicciones de todo el mundo o por regiones, para el estudio de diversos principios garantizados por las constituciones.

La cultura interna jurídica está constituida por las actitudes, las creencias, los razonamientos, las percepciones y los valores más o menos explícitos, comunes a un grupo de profesionales del derecho. Así, los juristas del Common Law tienen una cultura oral, la de la audiencia, mientras que sus homólogos franceses se han inclinado al escrito y al expediente. Cada cultura escoge formular o esconder los diferentes momentos del proceso judicial. La cultura jurídica anglosajona tiende a formular las reglas o códigos éticos.

Cada cultura judicial tiene una vertiente popular, que no se deja ver jamás de mejor forma que en las artes aparentemente alejadas del derecho, como el cine, el teatro o la literatura, y hasta las series de televisión. Los filmes franceses y americanos muestran dos imaginarios bien diferentes, que no provienen ni de la misma relación con la verdad (aquí, una especie de trascendencia que contrasta con la idea de verosimilitud que caracteriza a las culturas del Common Law), ni de la misma relación con el dinero (el abogado en Francia es representado con mucha frecuencia como un ser banal, interesado y sin escrúpulos), ni, finalmente de la misma relación con el procedimiento. 
Una concepción de la cultura judicial tiene el mérito de no limitarse al derecho, sino de abarcar también las prácticas, la cultura judicial francesa se interesa no solamente por la jurisprudencia, sino también por los métodos de trabajo y se aproxima a la sociología para complementar las jurisprudencias penales mediante la observación de las prácticas punitivas. Las prácticas punitivas francesas muestran, en efecto, una sensibilidad particular a la dignidad.

Una concepción amplia de una cultura judicial de un país, no solamente abarca las prácticas de los tribunales sino también las realidades sociales, como de orden antropológico. En Estados Unidos la consumación del derecho, de una parte, y el procedimiento acusatorio, de otra, están destinados a apartar la violencia a través del combate judicial.

Refieren Garapon y Papadopoulos (2010: 21) sobre el Common Law, ¿Por qué ciertas culturas están más dirigidas hacia el derecho? ¿Cómo justificar la repartición de las culturas occidentales entre culturas jurídicas y culturas políticas? El caso de Inglaterra y del Common Law debe ser analizado con una excepción, de la cual es necesario buscar el origen en una historia política original que consagró muy pronto la anterioridad del derecho en relación con el gobierno, lo que se traduce en la escogencia del precedente más que la ley como vehículo del derecho.

Con relación a si es ley o precedente, los autores afirman que la anterioridad del derecho se traduce técnicamente por la doctrina del precedente. Según la frase célebre de Geldard (cf Garapon y Papadopoulos, 2010: 68), si todas las leyes del reino debieran ser 
abrogadas, Inglaterra aún poseería un sistema de derecho. El Common law nace en la ideología de los juristas ingleses, siempre ha existido y, sin embargo, no tiene pasado.

En los sistemas del derecho romano-germánico, la ley es la fuente primaria del derecho. Esto no quiere decir que la jurisprudencia no juega allí ningún rol, las reglas, por definición generales, piden ser aplicadas. El precisador de la norma es el juez, aún más por estar en la obligación de pronunciarse. La regla de derecho puede, entonces, ser una regla despejada por la doctrina o enunciada por el legislador. Este trabajo de interpretación puede suceder que el juez modifique en forma considerable el alcance de la ley, pero ese poder nunca podrá ser asumido como tal en la cultura romano-germánica, según lo cual todo asunto ya está juzgado por el código. En este sistema teóricamente autosuficiente, la jurisprudencia no es considerada como una delas fuentes formales de derecho y no liga, en principio, a las jurisdicciones.

Esta desaparición del juez, aun cuando crea efectivamente derecho, contrasta con el Common law, en el que la jurisprudencia es la principal fuente de derecho. El Common law designa el conjunto de estas reglas susceptibles de ser subsumidas a partir de decisiones particulares. En el fondo del Common law se encuentra, entonces, la regla del precedente. Una vez que una decisión ha sido tomada, la misma debe ser proferida en todos los casos de especie similar por todas las jurisdicciones. En casos muy excepcionales, la jurisdicción suprema puede cambiar la jurisprudencia, teniendo como objeto garantizar cierta seguridad jurídica, la distinción y el cambio jurisprudencial le otorga al Common law una relativa flexibilidad (Garapon y Papadopoulos, 2010: 35-36). 
El Common law entonces, no reenvía a una técnica de interpretación, sino a un método de diferenciación a partir de casos de especie ya solucionados.

Entrando en conclusión del Common law, según el autor Bernate (2014: 250-251), en su libro "El Sistema Penal del Common Law", puntos de contacto y perspectivas para la legislación colombiana, refiere cómo la jurisprudencia como fuente directa del derecho penal pierde valor en los sistemas del Common law que rechazan la posibilidad de crear delitos o penas por vía del poder judicial, y en caso contrario, esto es, cómo la legalidad estricta pierde valor en los sistemas del civil law y lo gana en los sistemas del Common law. Es así que, por la vigencia estricta del principio de legalidad, se rechaza cualquier intento para dar mayor preponderancia al poder que tienen los jueces para crear delitos. Así mismo el autor refiere en este punto que el sistema legal colombiano debe acercarse al sistema de Common law y respetar el principio de legalidad, privando a los jueces de la capacidad de crear delitos.

\section{Problemática del antecedente y del precedente judicial en Colombia}

Los jueces en Colombia, quienes ejercen funciones públicas, tendrán el deber jurídico de tener en cuenta y aplicar el precedente judicial, llamémoslo así, inicialmente. Este viene siendo aceptado por la comunidad de operadores jurídicos y hace parte de nuestro sistema de fuentes del derecho.

En Colombia puede establecerse la existencia de dos clases de precedente judicial: uno, el que emana de la Corte Constitucional y otro, el que elaboran los demás tribunales 
y juzgados del país. El primero, podríamos decir que existe desde la sentencia C-104 de 1993; y el segundo desde la sentencia C-836 de 2001.

Al referirnos al precedente de la Corte Constitucional podríamos establecer una distinción que la misma corporación hace y no de una forma muy clara y se trataría de la diferencia entre el decisum y la ratio decidendi en las sentencias de constitucionalidad.

Pues bien, al atribuir ambos conceptos, al del decisum y al de la ratio decidendi, la misma cualidad: gozar de cosa juzgada erga omnes, y distinguirlos en sus fallos de constitucionalidad, principalmente, por el carácter explícito o implícito de esta cualidad, pareciera sensato concluir que ambas partes de la sentencia de constitucionalidad constituyen especies de un mismo género: el de precedentes judiciales de la Corte Constitucional; más esto no es correcto: ni la decisión de la Corte Constitucional de declarar exequible una norma jurídica, ni la decisión de declararla inexequible son normas jurídicas, y al no ser normas jurídicas, no son precedentes.

Analizado brevemente lo anterior, se podría concluir que si es precedente la ratio decidendi de las sentencias de constitucionalidad. Por una parte, la norma o normas jurídicas de carácter general y abstracto que motivan la decisión de declarar inexequible o exequible una determinada disposición, esto es, la ratio decidendi de las sentencias de constitucionalidad, sí constituyen precedentes judiciales en el derecho colombiano. Es así a partir de la sentencia C-104 de 1993. En esa sentencia la Corte Constitucional planteó dos posturas, la primera afirma que la ratio decidendi de las sentencias de constitucionalidad es precedente judicial de carácter obligatorio; y la segunda, que este era el único precedente aplicable en Colombia, pues, en tanto heredera de la tradición 
jurídica latina, en el país, la jurisprudencia de los demás tribunales y jueces solo podría jugar un papel auxiliar.

Sobre esta segunda postura, la Corte en sentencia C-104 de 1993 refirió: "se observa que entre la jurisprudencia de la Corte Constitucional y el resto de jurisprudencia de los demás jueces y tribunales del país existen semejanzas y diferencias".

En cuanto a las diferencias en el hecho de que mientras la jurisprudencia de los jueces no constituye un precedente obligatorio, tales providencias solo tienen un carácter de criterio auxiliar, Articulo 230 Constitución Política, para los futuros casos similares, la jurisprudencia constitucional tiene fuerza de cosa juzgada constitucional (Art. 243 Constitución Política).

También debemos analizar que es precedente la ratio decidendi de las sentencias de tutela. Así en la sentencia T-260 de 1995, la Corte Constitucional manifestó por primera vez que los fundamentos esenciales de sus fallos de tutela, también constituían precedente obligatorio para la guarda y protección de derechos fundamentales: en últimas, la Constitución Política es una sola y el contenido de sus preceptos no puede variar indefinidamente, según el criterio de cada uno de los jueces llamados a definir los conflictos surgidos en relación con los derechos fundamentales.

Como esta corporación lo ha sostenido repetidamente, uno de los principios de la administración de justicia es la de la autonomía funcional del juez, en el ámbito de sus propias competencias (Corte Constitucional. Sala Plena. Sentencia C-543 del $1^{\circ}$. De octubre de 1992), pero ella no se confunde con la arbitrariedad del fallador para aplicar 
los preceptos constitucionales. Si bien la jurisprudencia no es obligatoria (Art. 230 de la Constitución Política), las pautas doctrinales trazadas por esta Corte, que tiene a su cargo la guarda de la integridad y supremacía de la carta política, indican a todos los jueces el sentido y los alcances de la normatividad fundamental y a ellas deben atenerse. Cuando la ignoran o contrarían no se apartan simplemente de una jurisprudencia, como podría ser la penal, o la contenciosa administrativa, sino que violan la Constitución, en cuanto la aplican de manera contraria a aquella en que ha sido entendida por el juez de constitucionalidad a través de la doctrina constitucional que le corresponde fijar. (Sentencia T-260 de 1995. M.P. José Gregorio Hernández)

Podríamos entender que el precedente de la Corte Constitucional se configura con una sola sentencia, la doctrina y la jurisprudencia suelen aludir a un conjunto de decisiones uniformes respecto a un mismo punto de derecho, lo que equivale a decir que este nace cuando la ratio decidendi se reitera en varias providencias. La Corte Constitucional prescinde de esta reiteración como requisito para la configuración de sus precedentes, los cuales, en adelante, obligan inmediatamente se profieren.

El precedente de los demás juzgados y tribunales del país tienen referencia sobre la sentencia C-836 de 2001, esta es otra sentencia de aquellas que llaman hito para el derecho colombiano en tanto introduce el precedente judicial en nuestro sistema de fuentes de derecho, sin restringirlo ya a la jurisprudencia de la Corte Constitucional. Acudiendo a la imagen de la pirámide normativa inmortalizada por Hans Kelsen, se vería que, en uno de los escalones de la pirámide formada por nuestro ordenamiento, están las 
motivaciones de los jueces a sus sentencias, o al menos cierta clase de estas motivaciones.

Conducirnos hacia un sistema con precedentes, la Corte Constitucional tuvo que responder dos interrogantes: ¿Pueden los jueces de instancia apartarse de las decisiones tomadas por el tribunal de cierre en su respectiva jurisdicción?; ¿Pueden estos tribunales apartarse de su propio precedente? En ambos casos la respuesta fue negativa (Contreras, 2011).

Los fundamentos de esta decisión han sido retomados una y otra vez por las sentencias de la Corte Constitucional, y ya ha habido doctrina nacional preocupada por su estudio y aplicación.

Respecto de la norma jurídica sobre el deber de aplicar el precedente, sería más difícil que encontrar y formular adecuadamente el enunciado normativo sobre el deber de aplicar el precedente, es desentrañar los efectos jurídicos del sentido o norma que contiene: ¿Quiénes son sus destinatarios?; ¿Por qué se trata de un verdadero deber jurídico?; ¿Cuál es su jerarquía en el sistema de fuentes del derecho colombiano?

Respecto del destinatario de la norma, los planteamientos más destacados del positivismo jurídico entendido como teoría del derecho, fue considerar que los destinatarios de las normas jurídicas no son los ciudadanos, sino los órganos judiciales encargados de ejercer el poder coactivo (Contreras, 2011).

Esta teoría fue sostenida por varios filósofos del derecho y communis opinio durante casi todo el siglo XX, gracias en buena medida, a los excelentes escritos de Hans Kelsen, para quien la norma primaria, la única auténticamente jurídica, es aquella que 
prescribe un acto coactivo, es decir la que establece el deber de imponer una sanción luego de verificada una cierta condición. Desde esta teoría el ejercicio del poder coactivo es monopolio exclusivo del Estado, lo lógico es que solo los jueces, que son una clase de servidores del Estado, sean los destinatarios de las normas jurídicas (Contreras, 2011).

Una vez planteadas las teorías y doctrinas respecto de la discrecionalidad judicial, y algunos temas esenciales del proceso penal acusatorio, haciendo énfasis en el Common Law y criterios del precedente judicial en Colombia, el siguiente tema del trabajo, se enfocará en factores determinantes de la problemática del sistema penal acusatorio en Colombia.

\section{Capitulo II: Problemática del sistema penal acusatorio colombiano. Ley 906 de}

\section{4.}

En la investigación de este tema se analizaron los siete problemas más importantes que tienen un efecto negativo en el desarrollo actual del nuevo sistema penal acusatorio en Colombia, en relación con las decisiones judiciales. Al inicio de cada una de ellas se justifica por qué se toman en cuenta cada uno de estos factores. 


\section{Acción de tutela contra decisiones judiciales}

La figura de Acción de Tutela se hace necesario plantearla dentro de esta investigación, ya que, a través de la misma, como figura de protección de derechos fundamentales tiene un efecto sobre las decisiones judiciales que se han tomado y que en muchos casos al invocar esta figura modifica parcial o totalmente la decisión o decisiones anteriores, lo cual genera una amplia discrecionalidad de criterios, es por ello que se incluye a modo ilustrativo de la discrecionalidad del juez penal. A continuación, se expondrán los últimos criterios y planteamientos sobre la Tutela contra sentencias sobre las decisiones de las Altas Cortes.

Una de las más importantes limitaciones al ejercicio de la tutela fue plasmada en la Sentencia C-543 de 1992. En aquella oportunidad la Corte declaró inexequibles los artículos 11 y 40 del Decreto 2591 de $1991^{4}$, que consagraban como regla general la procedencia de la tutela contra sentencias. La Corte declaró que, si bien los funcionarios judiciales son autoridades públicas, debido a la relevancia de los principios de seguridad jurídica, cosa juzgada y autonomía e independencia judicial, la tutela sólo puede tener carácter excepcional frente a actuaciones de hecho que representen una grave afrenta a los derechos fundamentales. Dijo al respecto:

\section{Sentencia C/543 de 1992}

"Ahora bien, de conformidad con el concepto constitucional de autoridades públicas, no cabe duda de que los jueces tienen esa calidad en cuanto les corresponde la función de administrar justicia y sus resoluciones son obligatorias para los particulares

\footnotetext{
${ }^{4}$ Decreto 2591 de 1991, "por el cual se reglamenta la acción de tutela consagrada en el artículo 86 de la Constitución Politica”
} 
y también para el Estado. En esa condición no están excluidos de la acción de tutela respecto de actos u omisiones que vulneren o amenacen derechos fundamentales, lo cual no significa que proceda dicha acción contra sus providencias. Así, por ejemplo, nada obsta para que por la vía de la tutela se ordene al juez que ha incurrido en dilación injustificada en la adopción de decisiones a su cargo que proceda a resolver o que observe con diligencia los términos judiciales, ni riñe con los preceptos constitucionales la utilización de esta figura ante actuaciones de hecho imputables al funcionario por medio de las cuales se desconozcan o amenacen los derechos fundamentales, ni tampoco cuando la decisión pueda causar un perjuicio irremediable, para lo cual sí está constitucionalmente autorizada la tutela pero como mecanismo transitorio cuyo efecto, por expreso mandato de la Carta es puramente temporal y queda supeditado a lo que se resuelva de fondo por el juez ordinario competente (artículos 86 de la Constitución Política y $8^{\circ}$ del decreto 2591 de 1991). En hipótesis como éstas no puede hablarse de atentado alguno contra la seguridad jurídica de los asociados, sino que se trata de hacer realidad los fines que persigue la justicia.

De las razones anteriores concluye la Corte que no procede la acción de tutela contra ninguna providencia judicial, con la única salvedad del perjuicio irremediable, desde luego aplicada en este evento como mecanismo transitorio supeditado a la decisión definitiva que adopte el juez competente”.

Sentencia C-590 de 2005

En este fallo la Corte se pronunció sobre la constitucionalidad de la norma procesal (Art. $185 \mathrm{CPP}$ ) que establecía que contra la sentencia que resuelve el recurso 
extraordinario de Casación - no procedía ningún recurso -. En esta oportunidad la honorable Corte Constitucional afirmó:

“SENTENCIA DE CASACIÓN PENAL-Procedencia de la acción de tutela

Es manifiesta la inconstitucionalidad del aparte demandado del artículo 185 de la Ley 906 de 2004 ya que al indicar que contra la sentencia que resuelve el recurso extraordinario de casación en materia penal "no procede ningún recurso ni acción, salvo la de revisión”, está excluyendo la procedencia de la acción de tutela contra ese tipo de pronunciamientos y con ello, qué duda cabe, está contrariando el artículo 86 de la Carta Política ya que, como se ha visto, esta norma no excluye tales pronunciamientos de ese mecanismo de protección de los derechos fundamentales. Es decir, en tanto que la voluntad del constituyente expresada en la norma superior ya indicada fue que la acción de tutela se aplicara respecto de los actos y omisiones de las autoridades públicas, incluidas las judiciales, el legislador ha tomado la decisión, manifiesta en la norma demandada, de excluir de la procedencia de ese recurso las sentencias que resuelven la casación penal. Entonces, como es claro que una ley ordinaria no puede, bajo ninguna circunstancia, modificar o suprimir la Constitución Política y mucho menos uno de los mecanismos constitucionales de protección de los derechos fundamentales, la expresión “ni acción” que hace parte del artículo 185 de la Ley 906 de 2004 será expulsada del ordenamiento jurídico pues genera un espacio institucional en el que los derechos fundamentales no podrían ser protegidos”

Según ha sido explicado por la Corte en varias oportunidades, la Sentencia C-543 de 1992 apuntó a "la preservación de la supremacía de los derechos fundamentales, a 
través del entendimiento sustancial de los principios de seguridad jurídica e independencia judicial, es decir, que las sentencias judiciales deben tener un mínimo de

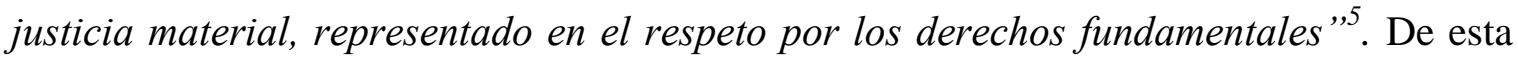
manera la ratio decidendi del fallo no fue otra que excluir la tutela contra sentencias judiciales como estaba originalmente prevista en el Decreto 2591 de 1991, esto es, como regla general, abierta e indiscriminada, para permitir su ejercicio restringido y verdaderamente excepcional $^{6}$.

La Sala considera importante reiterar que todos los jueces tienen el deber de cumplir y hacer cumplir la Constitución, no sólo cuando tramitan acciones de tutela o cuando hacen parte de la jurisdicción constitucional en sentido funcional ${ }^{7}$, sino también cuando actúa de ordinario en los asuntos propios “omnipresencia” de la Constitución en todas las áreas jurídicas y porque "un rasgo típico del constitucionalismo contemporáneo es la competencia que corresponde a los jueces ordinarios para que resuelvan los litigios a la vista de todo el ordenamiento jurídico, incluida por tanto la Constitución” (Prieto, 2003. Pag 116).

Finalmente indicó:

“23. En este marco los casos en que procede la acción de tutela contra decisiones judiciales han sido desarrollados por la doctrina de esta Corporación tanto en fallos de constitucionalidad, como en casos de tutela. Esta línea juridisprudencial, que se reafirma por la Corte en esta oportunidad, ha sido objeto de detenidos desarrollos en virtud de

\footnotetext{
${ }^{5}$ Corte Constitucional, Sentencia T-737 de 2007, T-018 de 2008, T-1049 de 2008, T-1112 de 2008, T-1150 de 2008, T-156 de 2009 y T-064 de 2010.

${ }^{6}$ CFR Corte Constitucional, Sentencias SU-058 de 2003, T-598 de 2003, T-598 de 2003, T-932 de 2003, T462 de 2003, T-200 de 2004, entre otras.

${ }^{7}$ CFR Corte Constitucional, Sentencias C-037 de 1996 y C-713 de 2008.
} 
ellos, la Corporación ha entendido que la tutela sólo puede proceder si se cumplen ciertos y rigurosos requisitos de procedibilidad. Dentro de éstos pueden distinguirse unos de carácter general que habilitan la interposición de la tutela, y otros de carácter específico, que tocan con la procedencia misma del amparo, una vez interpuesto."

La Corte debe reconocer que estos parámetros no son construcciones teóricas depuradas ni tienen pretensiones dogmáticas definitivas, sino que más bien nace ante la necesidad de dar respuesta a los problemas constitucionales que día tras día se derivan de la práctica judicial, cuando en ellas se involucran cuestiones referentes al alcance y límite.

- De un lado, el Decreto 1382 de 2000 consagra reglas específicas en materia de tutela contra providencias judiciales en lo que tiene que ver con las demandas contra la Corte Suprema de Justicia, el Consejo de Estado y la Sala Jurisdiccional Disciplinaria del Consejo Superior de la Judicatura. Así, el artículo $2^{\circ}$ atribuye a las propias corporaciones el trámite y conocimiento de las acciones de tutela, por supuesto con exclusión de los jueces que emitieron el fallo acusado.

Al examinar la validez del referido decreto, el Consejo de Estado reafirmó la procedencia de las acciones de tutela contra las acciones u omisiones de cualquier autoridad pública “incluidas las de la rama judicial y aún sus órganos supremos”.

Según el artículo 86 de la Constitución Política, la solicitud de tutela procede frente a una "acción u omisión" de cualquier autoridad, incluidas las de la rama judicial, y aún sus órganos supremos. 
Como se observa, el pronunciamiento del Consejo de Estado guarda plena sintonía con la postura de la Corte Constitucional en la materia.

De otro lado, es preciso tener en cuenta que la acción de tutela en estos eventos no explica por qué el juez constitucional nunca se equivoque y los tribunales supremos de la jurisdicción ordinaria o contenciosa administrativa sí lo hagan, pues es claro que la infalibilidad no es propiamente una virtud humana. De hecho, una prueba de que la Corte Constitucional también yerra en sus decisiones es que algunas de sus sentencias han sido anuladas por la propia Corte, cuando, por ejemplo, advierte graves y trascendentales violaciones al debido proceso o cuando alguna de las Salas de revisión ha desconocido la jurisprudencia de la Corte.

Por lo mismo, "la tutela contra providencias judiciales de las altas Corporaciones es más restrictiva, en la medida en que sólo tiene cabida cuando una decisión riñe de manera abierta con la Constitución y es definitivamente incompatible con la jurisprudencia trazada por la Corte Constitucional al definir el alcance y límites de los derechos fundamentales o cuando ejerce el control abstracto de constitucionalidad, esto es, cuando se configura una anomalía de tal entidad que exige la imperiosa intervención del juez constitucional. En los demás eventos los principios de autonomía e independencia judicial, es especialmente la condición de órganos supremos dentro de sus respectivas jurisdicciones, exigen aceptar las interpretaciones $y$ valoraciones probatorias aun cuando el juez de tutela pudiera tener una percepción diferente del caso y hubiera llegado a otra conclusión ${ }^{\prime \prime}{ }^{8}$

\footnotetext{
${ }^{8}$ Cfr. Corte Constitucional, Sentencia C-590 de 2005.
} 
Finalmente, con miras a garantizar una mayor coherencia y rigor en el examen de la tutela contra sentencias proferidas por las altas corporaciones judiciales, el artículo 54A del Acuerdo 01 del 3 de diciembre de 2008, estipuló el deber de presentar ante la Sala Plena de la Corporación los fallos sobre acciones de tutela contra providencias de la Corte Suprema de Justicia y del Consejo de Estado, para que la plenaria determine si asume directamente el estudio del caso.

\section{Falta de jueces, crisis de la justicia}

La problemática que vive Colombia en las últimas décadas que tiene relación indirecta con la decisión de los jueces y que se torna desbordada frente a este fenómeno, es la falta de jueces penales de todo orden y de los jueces de ejecución de penas, pues esto conlleva que la gran cantidad de procesos que se adelantan, se acumulen, como es el caso, hoy en día, del sistema penal acusatorio, lo que hace que los fallos se resuelvan de una manera apresurada, sin que las decisiones se hagan con un estudio detenido, profundo y jurídico y por lo tanto, en muchísimos casos se acuda a la jurisprudencia más a la mano, para resolver.

Para resolver la gran cantidad de casos represados en los despachos judiciales, según lo muestran las mismas estadísticas del Consejo Superior de la Judicatura y de otros órganos de la rama judicial. Sin embargo, a pesar de aceptar el Consejo Superior de la Judicatura que ha existido insuficiencia de despachos judiciales y por ende de jueces y funcionarios judiciales que le den trámite y resuelvan los casos que están archivados y represados, se crearon despachos de descongestión con funcionarios y jueces 
provisionales para solucionar la crisis especialmente de falta de jueces y concretamente para el sistema penal acusatorio, ley 906 de 2004 (Anexo 2).

Sin embargo, el Consejo Superior de la Judicatura dentro del programa de descongestión del sistema penal acusatorio, decidió desvincular a los jueces y funcionarios de estos despachos, generando nuevamente una crisis de la justicia, especialmente para poder tomar una decisión judicial sobre los casos de carácter penal que tanto víctimas como implicados esperan que se resuelva su situación.

La mayor crítica a esta problemática de creación de jueces de descongestión, la no creación permanente de jueces de conocimiento, la desvinculación de los jueces de descongestión, demuestra que no ha habido una medida eficaz, un estudio ponderado serio y responsable por parte de esta Corporación para solucionar la preocupante crisis que permitan cumplir de una forma actualizada y seria con el fin de la justicia en el campo penal, pues se terminan creando despachos, luego reduciéndolos, sin que haya una continuidad en la prestación del servicio que le garanticen al ciudadano el mismo desarrollo y eficacia en la culminación de los procesos penales.

En el análisis de la propuesta de reforma a la justicia no se observa una solución a la crisis de congestión como muchos medios de comunicación y representantes del cuerpo legislativo y funcionarios estatales pretenden plantear una solución.

Existe una problemática en cuanto a los jueces de ejecución de penas respecto de la insuficiencia de jueces y funcionarios para resolver sobre libertades de personas privadas de la libertad, ya sea para obtener beneficios administrativos o para el cumplimiento de penas, generando así un hacinamiento en las cárceles, a causa de la 
demora en resolver estos beneficios. (Ver estadísticas de jueces de ejecución de penas y hacinamiento en las cárceles)

\section{Control formal y material de la formulación de imputación y de la formulación de la acusación}

En esta problemática, quizá una de las más complejas que se presenta a diario y en especial en la formulación de la imputación en el sistema penal acusatorio, ya que no tiene un control material como tampoco lo tiene la formulación de la acusación, genera que las imputaciones por parte de los jueces de garantías se conviertan en imputaciones sin control, por sus sinnúmero de delitos o circunstancias de agravación como ejemplo, los cuales no proceden, pues los fiscales son los titulares de la acción penal, convirtiéndose las decisiones de los jueces sin control en la discrecionalidad en la legalización de las imputaciones. De similar forma ocurre con el control material de la acusación, pues los jueces de conocimiento no ejercen dicho control.

La formulación de la imputación como una de las etapas del proceso penal debe ser coherente con los principios y derechos constitucionales, ubicando al juez para cumplir su deber acatando la Constitución Política colombiana de 1991.

Según el artículo 250 de la Constitución política, modificado por el artículo $2^{\circ}$. Del Acto Legislativo No. 03 de 2002 en cuanto a la obligación de la Fiscalía General de la Nación de adelantar el ejercicio de la acción penal siempre y cuando medien suficientes motivos y circunstancias fácticas que indiquen la posible existencia de un delito; siendo este el umbral de la investigación que conduce a la formulación de la imputación. Ubicando, como se planteó antes, al juez, a dar estricto cumplimiento al 
artículo 29 de la Constitución colombiana, o sea al debido proceso que se aplicará a todas las actuaciones judiciales.

De lo anterior surge el problema en cuanto a la práctica judicial colombiana en aplicar el sistema penal acusatorio para lograr la efectividad del debido proceso y el derecho de defensa a través de la formulación de la imputación. Pues no podemos desconocer la existencia de un estado social de derecho que respeta los derechos fundamentales. El problema o debate sobre la imputación radica en que carece de controles que garanticen el debido proceso y el derecho de defensa, debido a una equivocada interpretación del artículo 286 del C. de P.P. o por la equivocada decisión de los jueces al no verificar el aspecto fáctico de la imputación, ni la exigencia de la inferencia razonable, de que el imputado es autor o partícipe de una conducta punible.

Al observar que el juez es director del proceso y garante de los valores fundamentales, nos surge la pregunta sobre si puede ejercer el control a los yerros que alteran los derechos de las partes, ejerciendo un control material desde la formulación de la imputación; o si solamente el juez de control de garantías, como hemos dicho, como garante de los derechos fundamentales y del debido proceso, solo debe ejercer un control formal.

La formulación de imputación presentada por la fiscalía en la cual esta le comunica a una persona su calidad de imputado ante el juez de control de garantías, cuya función de este último es ejercer un control de carácter de garantía y decisión que tendrá que estar motivada como una obligación del juez de fundamentar su decisión ejerciendo un control y de qué naturaleza, ¿solo formal o además material? Pues si solo se hace de 
carácter formal, puede quedar al arbitrio del fiscal, lo cual conlleva a la violación directa del debido proceso, con incidencia en el derecho de defensa, situación ésta que de igual forma ocurre en cuanto al escrito de acusación, al tan solo ejercer un control formal. Entonces, ¿cuál sería la función del juez de control de garantías y del juez de conocimiento si estos no pueden ejercer el control material? En primer lugar, la formulación de imputación, como un solo acto de comunicación y entonces ajena a los principios, valores constitucionales y derechos fundamentales. En segundo lugar, en cuanto a la acusación, los efectos en relación con la congruencia fáctica son absolutos, mientras que la jurídica es relativa, como lo ha expresado la jurisprudencia y por ello los jueces equivocan el sentido de la Corte.

El sistema penal acusatorio soporta críticas provenientes de las altas cortes y en materia de imputación ante la crisis que enfrenta esta figura, nos preguntamos si ¿la formulación de imputación, en un verdadero sistema constitucional o debe suprimirse? Este planteamiento existe en un proyecto de ley para suprimir esta figura. Las decisiones judiciales, según los principios de la ley y los principios y valores constitucionales son una regla inaplazable en la aplicación del derecho. El incumplimiento de estos, genera el núcleo del problema.

La crítica conlleva a preguntarse ¿debe conservarse la formulación de imputación o esto implica romper con la estructura del proceso penal adversarial? O la formulación de imputación debe suprimirse o ubicarse esta audiencia en la audiencia de formulación de acusación, con su respectivo descubrimiento probatorio, como garante del derecho de defensa y del debido proceso. Pero no culminar esta audiencia, sin que el juez decida 
nada, sino ejerciendo un control formal y material. Frente a esta crítica podemos plantear que existe un distanciamiento por parte del juez de los principios y valores constitucionales, ubicándose entonces el juez, al dictar sus providencias, ante el sometimiento al imperio de la ley y observa tan solo la norma, la cual los jueces la entenderían como un problema de ley formal.

En esta crítica y a modo de conclusión, han sido cambiantes las posturas de la Corte Suprema de Justicia, sala penal, tanto de la imputación como de la acusación.

\section{Problemática actual con los preacuerdos y negociaciones: los allanamientos producen penas}

En el esquema de los acuerdos y preacuerdos en el sistema penal acusatorio colombiano, ley 906 de 2004, confluye uno de los temas más complejos del nuevo estatuto procesal. De su manejo coherente depende, en buena medida, la visión que hacia fuera del sistema tenga la comunidad social y jurídica: ¿Qué se negocia? ¿Alcances de la negociación? ¿Qué impacto tendría ello sobre las cifras de impunidad?, se trata de preguntas que han surgido en la práctica. Una preocupación concreta se suma a las ya expuestas: ¿Qué grado de consistencia es de esperar en relación con la teoría del delito, en la práctica diaria relacionada con las nuevas figuras anotadas? Esto es fundamental: la consistencia del derecho penal sustancial, debe mantenerse en este caso y en todos, como es, por ejemplo, y se ha discutido ampliamente en su momento, en el caso de la imputación. Si el derecho procesal penal es derecho constitucional aplicado, ello pasa desde luego por la consideración de que se trata de la concreción del derecho penal material basado en la carta política. El principio de legalidad y su concreción dogmática en la tipicidad como categoría central de la teoría del delito, no se pueden flexibilizar en 
función de pragmatismos extraños a la filosofía del nuevo estatuto procesal (Consejo Superior de la Judicatura, 2005).

En exposición oral de la ponencia de la Fiscalía General de la Nación para el Conversatorio sobre los preacuerdos se planteó un interrogante: ¿Es improcedente el preacuerdo cuando la fiscalía cuenta con evidencia física, elementos materiales de prueba o información legalmente obtenidos suficientes para acusar?

Se ha debatido respecto a este interrogante y se ha concluído que el único referente legal vinculado con la cantidad probatoria exigida en materia de preacuerdos y negociaciones, lo contempla el inciso $3^{\circ}$ del artículo 327 del Código de Procedimiento Penal y se refiere a la improcedencia para la aplicación de este mecanismo cuando no exista un mínimo de prueba que permita inferir la autoría o participación en la conducta y su tipicidad, exigencia que impide que una persona inocente pueda llegar a aceptar un preacuerdo o que el juez profiera un fallo de condena en su contra.

Debe tenerse en cuenta que la negociación preacordada de culpabilidad se enmarca en la renuncia del imputado o acusado a los derechos de no auto-incriminación, de tener un juicio público, contradictorio, entre otros y con inmediación de las pruebas contempladas; renuncia que no está supeditada a criterio alguno de quantum probatorio distinto del señalado en el inciso 3 del artículo 327 del Código de Procedimiento Penal Acusatorio, debiéndose señalar que en este último caso ello se justifica en tanto que la presunción de inocencia no puede desvirtuarse de cualquier manera o de modo arbitrario. 
Una aparente fortaleza de la labor investigativa desarrollada por la Fiscalía General de la Nación, no puede ser obstáculo para la celebración de una negociación preacordada de culpabilidad.

Hasta este momento se ha referido el principio de legalidad y su concreción dogmática en la tipicidad, pero resulta que en el cotidiano judicial y acudiendo a la figura de la imputación, concretamente en los artículos 287 y 286 establecen que la imputación es una acto de comunicación a una persona en calidad de imputado ante juez de control de garantías y que para determinar esta imputación el fiscal la hará cuando de los elementos materiales probatorios, evidencia física o de la información legalmente obtenida, se pueda inferir razonablemente que el imputado es autor o partícipe de un delito. Pero en esa labor judicial diaria ocurre que en la imputación de un delito se impute además una circunstancia de agravación, pero que en esta y basada en la apresurada labor investigativa y en especial en aquellos casos de captura en flagrancia, no existan esos elementos materiales probatorios o evidencia física para inferir las circunstancias de agravación, la cual en muchos casos como en el homicidio, duplica la pena, mediante la cual se le hace dicha imputación y como bien lo dice la norma, la imputación se hace ante el juez de control de garantías, quien no ejerce un control material respecto de la formulación de cargos.

El interrogante será ¿si esa imputación con una circunstancia de agravación no puede ser motivo de un control material, además de no existir, al menos, la evidencia sobre este tipo penal, entonces el principio de legalidad y de tipicidad como categoría de 
la teoría del delito, se estaría vulnerando y si el derecho procesal penal es un derecho constitucional aplicado, entonces el interrogante es ¿se puede llegar a una negociación o preacuerdo donde el agravante del tipo penal no existe? Y el imputado estaría presionado ante una negociación injusta, convirtiéndose en una negociación arbitraria, en donde la actividad del funcionario judicial de la fiscalía y el juez de garantías no ejercerían ni una labor, ni un control dentro de los principios y derechos constitucionales, terminando siendo una decisión y actuación arbitraria.

\section{Problemática del hacinamiento carcelario}

La problemática del hacinamiento carcelario se tiene en cuenta en esta investigación ya que frente a la imposición de las medidas de aseguramiento intramural y los fallos condenatorios con prisión en establecimiento carcelario, cuando estas desbordan la discrecionalidad de las decisiones de los jueces, en estos casos, como se expone a lo largo de este trabajo, conlleva a un alto número de personas detenidas generando un fenómeno mayor de hacinamiento carcelario.

La sobrepoblación y el hacinamiento en las cárceles del país a cargo del INPEC, impide el correcto funcionamiento del Sistema Penitenciario y Carcelario, generando la llamada emergencia carcelaria factor que conlleva a que los Establecimientos de Reclusión del Orden Nacional estén a punto de colapsar (Instituto Nacional Penitenciario, INPEC, 2013).

Entre las consecuencias más relevantes de esta crisis se encuentra la vulneración de los Derechos Humanos de los internos dado que imposibilita efectuar de manera adecuada, la clasificación de las personas privadas de la libertad en los centros de 
reclusión, de acuerdo a lo establecido en el Código Penitenciario y Carcelario, Artículo 62 "Los internos en los centros de reclusión serán separados por categorías, atendiendo a su sexo, edad, naturaleza del hecho punible, personalidad, antecedentes y condiciones de salud mental y fisica..."

Asimismo, la limitación y carencia de infraestructura adecuada, impide que el Instituto brinde las garantías mínimas de servicio en las áreas laboral, de salud, recreación, bienestar, educación y en general, todas las acciones encaminadas a preparar al condenado, mediante su resocialización, para la vida en libertad, con base en lo señalado en el Art. 143 del Código Penitenciario y Carcelario.

Es así como la sobrepoblación carcelaria no es una situación coyuntural, por lo cual debe ser abordada mediante el diseño de una política criminal integral, encaminada a minimizar el fenómeno y dignificar a las personas que se encuentran privadas de la libertad.

En este sentido, el 31 de mayo del presente año, mediante Resolución No. 1505 el INPEC declara el estado de Emergencia Penitenciaria y Carcelaria en los Establecimientos de Reclusión del Orden Nacional - ERON, con el fin de dar solución a la crisis que actualmente presenta el Sistema Penitenciario y Carcelario, ejecutando planes estratégicos que apuntan a la seguridad, atención, tratamiento y reinserción de la población carcelaria. Con fundamento en lo anterior, se crea el Plan de Emergencia Carcelaria que incorpora los Planes de Salud, Seguridad y Des hacinamiento (Instituto Nacional Penitenciario, INPEC, 2013).

Plan de Des hacinamiento (PLANDES) 
Líneas de acción:

- Redistribución de la población reclusa (Traslados y reclasificación de Establecimientos de Reclusión y convenios con municipios para recepción de internos).

- Diseño Plan Maestro de Infraestructura 60.000 (Corporación Andina de Fomento CAF - mega cárceles).

- Clasificación de la población reclusa.

- Libertad condicional.

- Domiciliarias (prisión y detención)

- Vigilancia electrónica.

- Profesionalización del personal.

Estrategias:

Mejoramiento de infraestructura física de los ERON (Plan Maestro de Infraestructura 60.000).

- Plan colonias: construcción de 10.000 cupos.

- Plan ampliación: construcción de 20.000 cupos.

- Plan emergencia: mantenimiento general de los 138 ERON en sus áreas de sanidad, ranchos, baterías sanitarias, cubiertas, mantenimiento de PTAP, PTAR, pozos profundos y reservorios, redes hidrosanitarias y eléctricas.

Conclusiones: 
- Durante lo corrido de 2013, no se han creado nuevos Establecimientos de Reclusión del Orden Nacional - ERON, ni se han ampliado cupos en los ya existentes.

- Los Establecimientos de Reclusión reportaron una población intramuros de 117.528 internos, de los cuales el $92.4 \%$ son hombres (108.550) e el $7.6 \%$ mujeres (8.978).

- Con respecto a la situación jurídica de la población reclusa, el 30.8\% está sindicado y el $69.2 \%$ condenado.

- Para el mes en estudio, la población reclusa superó en 41.802 internos, la capacidad de los ERON, para un índice de hacinamiento del 55.2\%.

- Las regionales con mayor sobrepoblación son Central con 9.447 internos y Occidental con 9.179 internos. Las regionales con mayor índice de hacinamiento son Noroeste $87.1 \%$ y Norte con $83.3 \%$.

- El incremento de población reclusa para el mes de mayo de 2013, comparativamente con enero del mismo año fue del $2.3 \%$.

- Históricamente, el rango más alto de población reclusa está entre los 30 y 44 años con el $51.8 \%$ de los internos, seguido de quienes tienen entre 18 y 29 años, con participación del $42.6 \%$.

- El 5.4\% de los reclusos aún son iletrados, sería importante verificar las condiciones por las cuales estas personas, 6.316 (incluidos hombres y mujeres), no asisten a la capacitación que es una política de Estado. 
- Sólo el $65.5 \%$ de los reclusos participa en actividades de trabajo, estudio o enseñanza.

- El $8.8 \%$ de los internos se encuentra en condiciones excepcionales, siendo la población más alta los afrocolombianos $41.1 \%$ y los de la tercera edad $29.3 \%$.

- Las modalidades delictivas más frecuentes por las que son judicializados los reclusos son: el hurto $18.2 \%$, homicidio $16.8 \%$, tráfico de armas $14.5 \%$ y tráfico de estupefacientes 14.2\%. Estos cuatro delitos alcanzan el 63,6\% de participación.

- El INPEC tiene bajo su custodia a 1.319 personas que en su oportunidad pertenecieron a la Fuerza Pública, Fuerzas Militares y otras entidades del Estado, constituyendo el $1.1 \%$ del total general de internos.

- Actualmente hay 15.020 personas con detención domiciliaria y 10.312 cumpliendo pena, para un total de 25.332 .

- Igualmente, 4.030 reclusos están bajo la medida de control y vigilancia electrónica.

- La población reclusa reincidente asciende a 15.786 personas, de las cuales 14.896 están internos en los establecimientos de reclusión, 814 en domiciliaria y 76 con control y vigilancia electrónica.

En un artículo periodístico (El Colombiano) se lee lo siguiente: "estar tras las rejas en Colombia se ha convertido, como la novela de Gabriel García Márquez, en una crónica de muerte anunciada, y así lo demuestra el incendio de esta semana en la Cárcel Modelo de Barranquilla que le costó la vida a diez reclusos y heridas a 42 más" (...) 
La precaria situación de los presos en Colombia se manifiesta en problemas de hacinamiento, insalubridad y riñas, una situación similar a la que se vive en las cárceles de otros países latinoamericanos.

Según cifras del Instituto Nacional Penitenciario y Carcelario (INPEC, 2013), el índice de hacinamiento en las cárceles del país era del 55.2 por ciento, superando en 41.802 internos la capacidad del Establecimiento Reclusorio de Orden Nacional e Internacional (ERON).

A pesar de que las cárceles de carácter nacional del país tienen capacidad para albergar a 76.066 presos, actualmente hay 120.387 reclusos que copan la capacidad del sistema penitenciario, una situación que es motivo de constantes llamadas de atención de instituciones que velan por los derechos humanos (INPEC, 2013).

"Actualmente el hacinamiento carcelario en Colombia alcanza el 58.3 por ciento, una cifra sin precedentes en la historia reciente del país, y en algunas cárceles llega hasta niveles del 400 por ciento", explicó el titular de la Defensoría del Pueblo, Jorge Armando Otálora Gómez.

Según el INPEC (2013), al cierre del año no se habían creado nuevos establecimientos de reclusión de orden nacional para mitigar la crisis causada por la deficiente capacidad del sistema.

A ese problema se suma el hecho de que cada mes llegan a las cárceles colombianas cerca de 3.000 presos y tan solo el 10 por ciento de los reclusos sale en libertad, lo que genera un creciente desequilibrio en el sistema penitenciario. 
Otálora dijo a la agencia de noticias Efe que, para mitigar esta situación, más que una ley, "se necesita reformar el sistema acusatorio, planear y construir nuevos centros carcelarios y penitenciarios, generar nuevos cupos en los centros existentes y construir una política estructural, no medidas aisladas".

De no tomarse estas medidas correctivas el sistema colapsaría, y más cuando en las cerca de 138 cárceles colombianas administradas por la Nación hay graves problemas de salud. Hepatitis, sarampión, tuberculosis y trastornos mentales son tan solo algunas de las enfermedades comunes entre los presos del país, 600 de los cuales están en estado terminal, según la Defensoría del Pueblo.

Según Otálora, la única Empresa Prestadora de Servicios (EPS) de salud que atiende a los presos "es una de las más quebradas y las demás no quieren hacerlo porque no les resulta rentable".

A las advertencias sobre la crisis carcelaria se sumó el ministro de Justicia, Alfonso Gómez Mendez, quien consideró inexplicables muchos hechos que ocurren en las cárceles del país y pidió mayor atención de los organismos de control. (Salazar Castellanos, El Colombiano, 2014).

También el senador Jorge Robledo, del Polo Democrático, se sumó al debate mediante una carta enviada al presidente Juan Manuel Santos en la que afirma que la situación actual "pone en evidencia la gravísima crisis humanitaria que sufren más de 120.000 personas recluidas en las cárceles del país". (Salazar Castellanos, El Colombiano, 2014). 
Según Robledo, “las cárceles colombianas están operando como una especie de centros de tortura". (Salazar Castellanos, El Colombiano, 2014).

Los diez muertos y las decenas de heridos que dejó el incendio de la cárcel en Barranquilla, según el Inpec provocado por los mismos reclusos en protesta por una operación de registro de los agentes penitenciarios, reflejan en parte el desespero de los reclusos del país que, según Otálora, "puede terminar en graves catástrofes y pérdidas humanas". (Salazar Castellanos, El Colombiano, 2014).

Igualmente se analizó la sentencia de tutela 762 de Diciembre 16 de 2015 sobre la política carcelaria existente hoy, en especial respecto de la declaratoria del ECI.

Acción de tutela resuelta por la Corte Constitucional. 


\section{Consejo Superior de la Judicatura \\ Sala Administrativa \\ Unidad de Desarrollo y Análisis Estadístico}

Descripción

Fuente de la información

Periodo

Destinatario
Gestión de los despachos judiciales penales del territorio nacional en tema de procesos rituados por la Ley 906 / 2004 SPOA.

Sistema de Información Estadístico de la Rama Judicial -SIERJU-

1 de enero de 2013 a 30 de septiembre de 2014

GERMAN ALONSO CASTAÑEDA TORRES

Consejo Superior de la Judicatura

Sala Administrativa

Unidad de Desarrollo y Análisis Estadístico

Información del 1 de enero al 30 de septiembre de 2014

\begin{tabular}{|c|c|}
\hline DELITO & $\begin{array}{l}\text { CANTIDAD DE } \\
\text { CONDENADOS }\end{array}$ \\
\hline Contra el patrimonio económico - Hurto & 4.471 \\
\hline Contra la seguridad pública - Concierto para delinquir & 1.912 \\
\hline $\begin{array}{l}\text { Contra la salud pública - Tráfico de estupefacientes y otras } \\
\text { infracciones }\end{array}$ & 1.432 \\
\hline Contra la seguridad pública - Otros & 847 \\
\hline Contra la vida y la integridad personal - Homicidio & 618 \\
\hline Contra la vida y la integridad personal - Lesiones personales & 377 \\
\hline Contra la familia - Violencia intrafamiliar & 264 \\
\hline $\begin{array}{l}\text { Contra la libertad, integridad y formación sexuales, de los actos } \\
\text { sexuales abusivos - Acceso carnal abusivo con menor de catorce } \\
\text { años }\end{array}$ & 193 \\
\hline $\begin{array}{l}\text { Contra la libertad, integridad y formación sexuales, de los actos } \\
\text { sexuales abusivos - Actos sexuales con menor de catorce años }\end{array}$ & 160 \\
\hline Contra la eficaz y recta impartición de Justicia & 140 \\
\hline
\end{tabular}




\section{Consejo Superior de la Judicatura}

Sala Administrativa

Unidad de Desarrollo y Análisis Estadístico

\begin{tabular}{|c|c|c|c|c|c|c|}
\hline \multirow[b]{2}{*}{ JURISDICCIÓN } & \multirow[b]{2}{*}{ COMPETENCIA } & \multirow[b]{2}{*}{ ESPECIALIDAD } & \multicolumn{2}{|c|}{2013} & \multicolumn{2}{|c|}{2014} \\
\hline & & & $\begin{array}{c}\text { CONDE } \\
\text { NADOS } \\
\text { ADULTOS }\end{array}$ & $\begin{array}{c}\text { CONDE } \\
\text { NADOS } \\
\text { ADOLES } \\
\text { CENTES } \\
\end{array}$ & $\begin{array}{c}\text { CONDENA } \\
\text { DOS } \\
\text { ADULTOS }\end{array}$ & $\begin{array}{c}\text { CONDENADO } \\
\text { S } \\
\text { ADOLESCENT } \\
\text { ES } \\
\end{array}$ \\
\hline Ordinaria & Juz. Circuito & Civil & 0 & 0 & 0 & 0 \\
\hline Ordinaria & Juz. Circuito & Familia & 0 & 1.202 & 0 & 824 \\
\hline Ordinaria & Juz. Circuito & Laboral & 0 & 0 & 0 & 0 \\
\hline Ordinaria & Juz. Circuito & Penal & 3.129 & 10.328 & 3.217 & 7.564 \\
\hline Ordinaria & Juz. Circuito & Promiscuo & 147 & 0 & 136 & 0 \\
\hline Ordinaria & Total Juz. Circuito & & 3.276 & 11.530 & 3.353 & 8.388 \\
\hline Ordinaria & Juz. Municipal & Civil & 0 & 0 & 0 & 0 \\
\hline Ordinaria & Juz. Municipal & Laboral & 0 & 0 & 0 & 0 \\
\hline Ordinaria & Juz. Municipal & Penal & 761 & 0 & 322 & 0 \\
\hline Ordinaria & Juz. Municipal & Promiscuo & 394 & 0 & 171 & 0 \\
\hline Ordinaria & Total Juz. Municipal & & 1.155 & $\mathbf{0}$ & 493 & $\mathbf{0}$ \\
\hline Ordinaria & Trib. Superior & Civil & 0 & 0 & 0 & 0 \\
\hline Ordinaria & Trib. Superior & Familia & 0 & 0 & 0 & 0 \\
\hline Ordinaria & Trib. Superior & Laboral & 0 & 0 & 0 & 0 \\
\hline Ordinaria & Trib. Superior & Penal & 3 & 0 & 1 & 0 \\
\hline Ordinaria & Trib. Superior & Sala Única & 13 & 0 & 3 & 0 \\
\hline Ordinaria & Trib. Superior & Salas Mixtas & 0 & 0 & 0 & 0 \\
\hline Ordinaria & Total Trib. Superior & & 16 & $\mathbf{0}$ & 4 & $\mathbf{0}$ \\
\hline Total Ordinaria & & & 4.447 & 11.530 & 3.850 & 8.388 \\
\hline
\end{tabular}




\section{Consejo Superior de la Judicatura \\ Sala Administrativa \\ Unidad de Desarrollo y Análisis Estadístico}

\begin{tabular}{|c|c|c|c|c|c|c|}
\hline \multirow[b]{2}{*}{ JURISDICCIÓN } & \multirow[b]{2}{*}{ COMPETENCIA } & \multirow[b]{2}{*}{ ESPECIALIDAD } & \multicolumn{2}{|c|}{2013} & \multicolumn{2}{|c|}{2014} \\
\hline & & & $\begin{array}{c}\text { CONDENA } \\
\text { DOS } \\
\text { ADULTOS }\end{array}$ & $\begin{array}{c}\text { CONDENADO } \\
\text { S } \\
\text { ADOLESCENT } \\
\text { ES }\end{array}$ & $\begin{array}{c}\text { CONDENA } \\
\text { DOS } \\
\text { ADULTOS }\end{array}$ & $\begin{array}{c}\text { CONDENA } \\
\text { DOS } \\
\text { ADOLESC } \\
\text { EN } \\
\text { TES }\end{array}$ \\
\hline Ordinaria & Juz. Circuito & Civil & 0 & 0 & 0 & 0 \\
\hline Ordinaria & Juz. Circuito & Familia & 0 & 1.202 & 0 & 824 \\
\hline Ordinaria & Juz. Circuito & Laboral & 0 & 0 & 0 & 0 \\
\hline Ordinaria & Juz. Circuito & Penal & 3.129 & 10.328 & 3.217 & 7.564 \\
\hline Ordinaria & Juz. Circuito & Promiscuo & 147 & 0 & 136 & 0 \\
\hline Ordinaria & Total Juz. Circuito & & 3.276 & 11.530 & 3.353 & 8.388 \\
\hline Ordinaria & Juz. Municipal & Civil & 0 & 0 & 0 & 0 \\
\hline Ordinaria & Juz. Municipal & Laboral & 0 & 0 & 0 & 0 \\
\hline Ordinaria & Juz. Municipal & Penal & 761 & 0 & 322 & 0 \\
\hline Ordinaria & Juz. Municipal & Promiscuo & 394 & 0 & 171 & 0 \\
\hline Ordinaria & $\begin{array}{l}\text { Total Juz. } \\
\text { Municipal }\end{array}$ & & 1.155 & $\mathbf{0}$ & 493 & $\mathbf{0}$ \\
\hline Ordinaria & Trib. Superior & Civil & 0 & 0 & 0 & 0 \\
\hline Ordinaria & Trib. Superior & Familia & 0 & 0 & 0 & 0 \\
\hline Ordinaria & Trib. Superior & Laboral & 0 & 0 & 0 & 0 \\
\hline Ordinaria & Trib. Superior & Penal & 3 & 0 & 1 & 0 \\
\hline Ordinaria & Trib. Superior & Sala Única & 13 & 0 & 3 & 0 \\
\hline Ordinaria & Trib. Superior & Salas Mixtas & 0 & 0 & 0 & 0 \\
\hline Ordinaria & \begin{tabular}{|l|} 
Total Trib. \\
Superior \\
\end{tabular} & & 16 & $\mathbf{0}$ & 4 & 0 \\
\hline Total Ordinaria & & & 4.447 & 11.530 & 3.850 & 8.388 \\
\hline
\end{tabular}




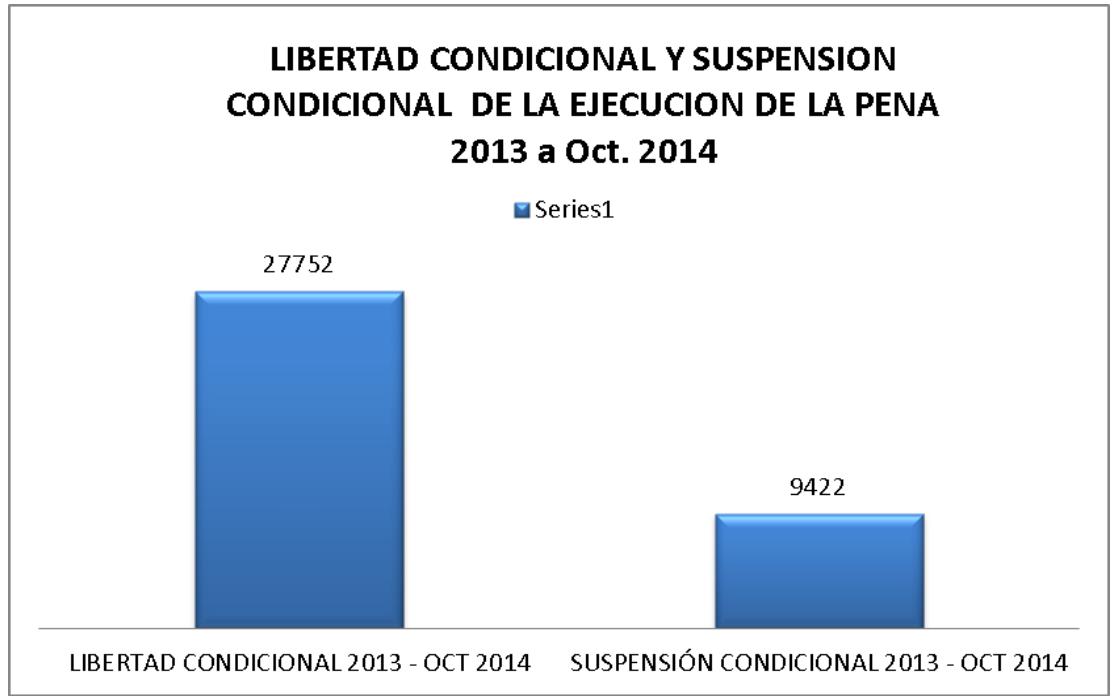

\section{Libertad condicional y suspensión condicional} de la ejecución de la pena 2013 a oct. 2014

\begin{tabular}{|l|c|}
\hline Fuerza pública de detención domiciliaria & $\mathbf{2 4 7}$ \\
\hline Libertad condicional 2013 - oct 2014 & 27752 \\
\hline Suspensión condicional 2013 - oct 2014 & 9422 \\
\hline
\end{tabular}

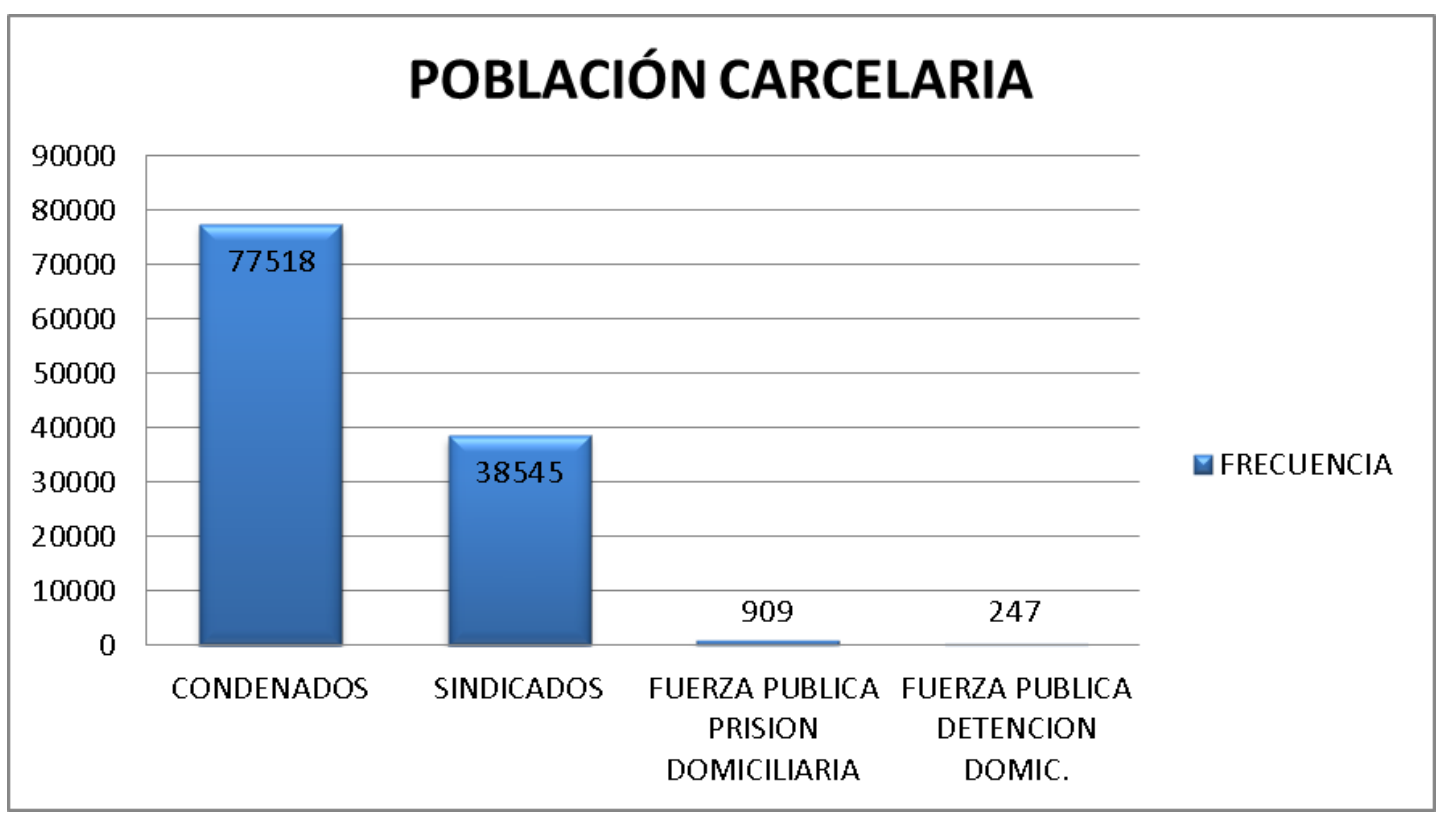




\section{Crítica al juez penal en Colombia con respecto a la educación en las facultades de derecho.}

La discrecionalidad judicial en las decisiones del juez penal tiene una raíz profunda en la formación de los profesionales del derecho, ya que los programas de derecho no cuentan con una preparación que proyecte la formación de jueces a través de las teorías de la discrecionalidad, ni las instituciones del Estado tienen una formación superior o especializada para quienes resuelven y toman decisiones en el campo penal.

En su escrito crítico "La Educación Legal como preparación para la jerarquía”, Kennedy (2000) expresa varias ideas sobre los inconvenientes en la formación de los futuros abogados. Hace una crítica a la educación y habla de que los estudiantes se forman en una jerarquía extrema, alumno-profesor, donde algunos estudian por elevar el status familiar y la experiencia en el aula es pasiva, tienen los alumnos una actitud pasiva hacia el contenido del sistema jurídico. Las facultades enseñan técnicas jurídicas en forma aislada del ejercicio profesional. Afirma el autor que lo que se necesita es pensar al derecho, de tal manera que sea posible entrar en él, criticarlo, pero sin rechazarlo completamente y manipularlo sin dejarse llevar por su sistema de pensamiento y funcionamiento. Afirma también que a través del programa de enseñanza se inculcan una serie de actitudes políticas acerca de la economía y de la sociedad en general, lo cual tiene un significado ideológico.

En relación con lo anterior, estoy de acuerdo con la crítica de Duncan Kennedy y su ocurrencia en Colombia, concretamente en dos aspectos: el primero, en cuanto a la crítica a la educación en el aula, cuando dice que es pasiva por parte del alumno y por parte del profesor también, hacia el contenido del sistema jurídico y el segundo en cuanto 
al sistema de pensamiento y funcionamiento. En nuestro país se observa la tendencia de solamente cumplir el modesto conocimiento impartido por el profesor y el alumno asimilar únicamente el tema, aspectos que son consecuencia de que el pensum es recortado y carente del tiempo suficiente para abordar cada tema, lo cual genera que haya mínimos o nulos espacios para una crítica sana y constructiva. Igualmente, la mayoría de abogados desarrollan sus estudios en las jornadas nocturnas, lo cual también limita el tiempo de enseñanza para el profesional que busca obtener su título de abogado.

Si bien es cierto, las facultades de derecho tienen una libertad de formación ideológica e inclinada por el sistema y concretamente el sistema colombiano, en un estado social de derecho, a pesar de que hemos recogido diversas teorías de muchos sistemas extranjeros en el área penal, desafortunadamente no se ejerce dentro de las facultades de derecho un sistema de pensamiento crítico que pueda ubicar quizás en una mejor conciencia de la realidad social y con esto podría conducir a un mejor funcionamiento de las instituciones del Estado y concretamente las instituciones pertenecientes a la rama judicial.

Se debería incluir en el plan de estudios de las facultades de derecho, una cátedra crítica de los sistemas con relación a la sociología de nuestro país, lo que permitiría tener un pensamiento más razonable y adecuado a las expectativas de las facultades.

\section{Eficientismo penal y populismo punitivo}

La creación continua de leyes de forma afanada y oportunista por parte del legislador, acompañada de poder político, han hecho que el contenido de dichas leyes vaya en detrimento de las bases filosóficas del derecho penal, además, con conceptos 
irracionales, ambiguos y confusos, lo cual genera que las decisiones tengan un campo abierto en su discrecionalidad.

Dentro de una crítica al sistema penal colombiano, referente a la ley 906 de 2004 , sistema penal acusatorio, que provino del Acto legislativo 3 de 2002 artículo $2^{\circ}$, que modificó el artículo 250 de la Constitución Política de Colombia con el cual se realizó una exhaustiva reforma al sistema penal colombiano en busca de obtener resultados de alta eficiencia, bajando los niveles de impunidad y menos crimen, me referiré a aspectos filosóficos y teóricos que se tuvieron en cuenta para justificar la reforma. En segundo lugar, analizar si ese aspecto de eficiencia punitiva refleja en la sociedad una reforma de eficiencia material o por el contrario, podría establecerse que la sociedad sería víctima de la pérdida de garantías de orden constitucional.

Sin ningún antecedente en el régimen del sistema de procedimiento penal colombiano que se conozca, el enjuiciamiento había tenido una reforma tan significativa, pues de un sistema inquisitivo, pasó a ser un sistema penal de corte acusatorio.

A pesar de la reforma jurídico-penal del sistema que requería análisis y estudios profundos para obtener eficientes resultados, de acuerdo al desenvolvimiento del nuevo sistema acusatorio en Colombia, pareciera que no se le dedicó el tiempo suficiente para que este no fuera tan superficial y pudiese manejarse con la mayor responsabilidad desde los antecedentes de la presentación de la propuesta, como el estudio en las diferentes Cámaras del Congreso para su aprobación. 
Para que su resultado no fuera inoperante y tuviese una verdadera aplicación en la sociedad colombiana, para aplicar un sistema de tendencia inquisitiva en el sistema penal acusatorio.

A partir de la Constitución de 1991 han existido varias modificaciones y reformas a nuestro sistema procesal penal "baste con señalar que el presente es el tercer código de procedimiento que se expide desde la promulgación de la constitución de 1991, con escasos trece años de vigencia, esto es, sin tener en cuenta las más de sesenta reformas que se le han introducido al ordenamiento penal en el mismo periodo". (Grosso, 2005) (Decreto 800 de 1991; 1833 de 1992; 1834 de 1992; 663 de 1993; 1108 de 1994; 1072 de 1995; 2100 de 1996; 2545 de 1997; 3000 de 1997; 3001 de 1997; 775 de 1998; 306 de 1998; 1818 de 1998; 261 de 2000; 262 de 2000; 652 de 2001; Las leyes: 23 de 1991; 15 de 1992; 40 de 1993; 58, 65, 66, 81 de 1993; 228 de 1995; 282, 294, 331, 333 de 1996; 360, 365, 383, 393, 415, 417 de 1997; 491, 504, 552 de 1999; 599 de 2000; 600 de 2000 entre otras).

Como puede verse de este sinnúmero de decretos, leyes y actos legislativos, el Estado pretende lograr una eficiencia en el camino penal, para así solucionar los diversos problemas sociales del país, denominándolo eficientismo. "La mayoría de las veces completamente ajenos al fenómeno legislativo mismo, práctica que, como ya se señaló, es propia de las precarias democracias autoritarias de nuestra región" (Fernandez Carrasquilla, 1992).

Desde la reforma o modificación del artículo 250 de la Constitución Política, el cual faculta a la fiscalía para ejercer y adelantar el ejercicio de la acción penal y 
siguiendo el contenido del mismo acto legislativo 03 de 2002 en su artículo $2^{\circ}$, fue así como el Fiscal General de la nación promovió la reforma del aludido del sistema penal acusatorio en Colombia, intentando justificar la necesidad de dicha reforma, planteando un incremento de la criminalidad en nuestro país, problemática de la guerrilla, tráfico de drogas, la pobreza y la desigualdad y la violencia entre otros, como igualmente refiriéndose a la historia del sistema penal acusatorio en la justicia de los Estados Unidos de América. Además, se refiere este autor en su investigación: "a los índices de criminalidad de los delitos de mayor ocurrencia, a la cabeza de los cuales se ubican el hurto, la violencia intrafamiliar, la inasistencia alimentaria y el homicidio. Luego, selecciona este último para hacer un análisis a partir de la tasa de homicidios cometidos por cada cien mil habitantes, que es el patrón estadístico universalmente aceptado para hacer una medición" (United Nations Survey of Crime Trends and Operations of Criminal Justice Systems, cf. Grosso, 2005)

Podríamos concluir que la reforma del sistema penal acusatorio ha estado soportada en estadísticas de índices de delitos y valga el análisis y estudio de conductas de bajo perfil en el ámbito punitivo de carácter social, como de parámetros universales de medición, pero llama la atención que no se hacen análisis sobre estadísticas de criminalidad de delitos de cuello blanco, de conductas cometidas por altos funcionarios del Estado o aquellos que en la actualidad el país conoce y que son de gran trascendencia en la afectación de las instituciones del estado colombiano y el efecto sobre la sociedad. Y se han limitado a los delitos de inasistencia alimentaria, de homicidio, de drogas, de terrorismo, excluyendo los índices de delitos de gran relevancia penal (Grosso, 2005). 
Me parece importante hacer comentarios de los apartes del autor, cuando refiere que el Fiscal General de la Nación hace una comparación entre el número de policías, fiscales y jueces encargados de reprimir la criminalidad y se vale de datos suministrados por las Naciones Unidas e INTERPOL. Examinando los datos sobre el número de funcionarios disponibles para perseguir los homicidios y haciendo paralelos entre varios países de América, Japón y demás países del planeta y concluye que Colombia es el país que comparativamente dispone de menos funcionarios para atender los casos de homicidio (Grosso, 2005).

Sin embargo, sigo pensando que no se refiere a los delitos de corrupción, los cuales son de igual importancia que los demás, si se quiere lograr un eficientismo penal, para que realmente la reforma penal, en un estado como el nuestro, logre garantizar la estabilidad de una sociedad y encontrar una verdadera justicia material.

El autor Manuel Salvador Grosso (2005) refiere respecto de los planteamientos del Fiscal General de la Nación: "Que de manera sorpresiva este dice: que las naciones con sistemas judiciales de tendencia acusatoria logran una mayor represión del crimen en las tres instancias, policial, judicial (jueces y fiscales) y encarcelamiento, con el resultado de lograr bajas tasas de criminalidad (homicidios), y que todo ello se debe, fundamentalmente, a que en los países con tendencia acusatoria aplican el principio de especialización, en virtud del cual "el Fiscal investiga a fondo y deja las funciones de administrar justicia a los jueces", concluyendo que "la mayor eficiencia de fiscales y jueces culmina con una mayor cantidad de delincuentes pagando condenas en prisiones”, con lo cual disminuyen la congestión, la impunidad y la criminalidad”. 
La anterior demostración, acata el alto funcionario, es razón suficiente para que el Congreso de la República se convenza de las bondades del sistema acusatorio y, en consecuencia, es más que abundante justificación para que se aprueben las reformas constitucional y legislativa propuestas. No cabe duda que el sistema acusatorio es el mejor instrumento para mejorar la convivencia pacífica de nuestro pueblo, ello sin dejar de lado las grandes ventajas económicas y financieras derivadas de una mayor eficacia en la administración de justicia.

Los anteriores planteamientos del Fiscal General de la Nación en esa oportunidad, no fueron más que una ligera y aventurada manifestación de momento, para convencer a un cuerpo legislativo y lograr implementar un sistema penal acusatorio con raíces de diversas tendencias filosóficas y jurídicas de muchos países, sin importar en el fondo, un estudio político, jurídico y social de nuestro estado, y sin haber estructurado un número suficiente de fiscales y jueces para verdaderamente lograr una eficiencia en la administración de justicia, ya que hoy se vive una de las peores congestiones, tanto en la fiscalías como en los juzgados, los mayores índices de impunidad y desafortunadamente, los mayores índices de hacinamiento carcelario, como lo revelan las estadísticas en esta investigación, la insuficiencia de jueces y fiscales y la precaria preparación de los mismos, como se muestra en las estadísticas del Consejo Superior de la Judicatura.

Manuel Salvador Grosso (2005) en sus planteamientos de eficientismo punitivista, se cuestiona se cuestiona ¿Justicia eficiente o justicia eficientista? Hemos analizado atrás los problemas coyunturales del sistema penal acusatorio colombiano, que actualmente rige en Colombia, el cual, en el afán, quizás legislativo y político y por decisión del 
constituyente, desencadenó de forma rápida el desarrollo de la ley que estableció el sistema acusatorio, que analizando su sistema de tendencia acusatoria adversarial oral se encuentra adverso a las garantías constitucionales y principios de un sistema de tendencia continental aun cuando es una mixtura de sistema anglo-sajón, continental y colombiano, sin tener claridad realmente de cuáles son los fines de una justicia penal .

Definiéndolo como un término jurídico el eficientismo deriva del latín eficientia, acción, fuerza, virtud de producir. Analizando el término de garantismo en el área penal, y como en alguna oportunidad el jurista Ferrayoli, planteaba que el galantismo es una obligación correspondiente a un derecho subjetivo, lo cual se concluye, que corresponde a una expectativa jurídica positiva o negativa, así diríamos que eficientismo y garantismo forman parte de una teoría jurídica de validez y por ello de efectividad, aun cuando diferentes los términos entre sí y no propiamente estos dos términos son un término jurídico, pero si una necesidad en el desarrollo de la práctica del derecho, especialmente en el campo penal, como lo quiso interpretar y plantear el doctor Carlos Ubate en uno de sus escritos sobre garantismo versus eficientismo.

Se hace necesario definir el estudio de la deontología o sea el término etimológico deontología que emana del griego, fruto de dos componentes de dicha lengua: Deontos, que puede traducirse como deber u obligación. Y logia que es sinónimo de estudio. Por lo tanto, se puede concluir que deontología es parte de la ciencia del deber ser y concretamente dentro del derecho, tiene su relación con el derecho en sí y concretamente con el derecho penal, respecto de la administración y planeación de toda institución que pueda organizar un sistema penal. 
La deontología como una ciencia del deber ser y obligación, enmarca entonces todo desarrollo institucional para obtener resultados eficientes. Y una eficiencia debe tener un talento humano y un soporte económico, un estudio estructural, aplicándolo a una planificación de carácter judicial para que existe una efectividad en la justicia y obtener, resultados positivos en su construcción legislativa como en la materialización del proyecto.

Si analizamos los términos de garantismo y eficientismo en el campo judicial en su aplicación, podemos establecer que en cuanto al eficientismo penal el Estado busca una lucha contra la impunidad a toda costa, como lo establece el jurista Hugo Montoya, aun con el desconocimiento de garantías procesales. De aquí puede desprenderse lo que denominaríamos populismo punitivo.

La deontología como ciencia del deber ser, tiene como propósito aumentar el bienestar y entonces el deontologismo en cuanto al desarrollo de una actividad procesal cuenta con los suficientes recursos, conduce a unos resultados eficientistas en la actividad judicial, efectividad y materialización de los derechos de las partes y usuarios de la justicia.

El populismo punitivo deriva de la propuesta de las iniciativas y proyectos por parte del Congreso y en algunos casos por iniciativa del Gobierno, como un denominador en otros casos de una política criminal. Proyectos sobre la ley penal, proyectos sobre la ley penal procesal, proyectos sobre incremento de penas, proyectos sobre corrupción, proyectos s obre la infancia y la adolescencia y demás infinidad de propuestas que se convierten en leyes. Especialmente conllevan a ese populismo punitivo el incremento de 
penas, como ocurrió en el caso concreto de la iniciativa legislativa para el aumento de penas dentro de los delitos sexuales contra menores que fue impulsado por la fallecida Senadora del Partido Verde, Gilma Jiménez y que surgió con mayor fuerza a raíz del caso del homicidio del menor del caso de Chía (Caso Pelayo) el cual tuve la oportunidad de asumir como defensor. Quien en este último caso reforzó las banderas políticas y acudía a todos los procesos de esta índole para fortalecer esa iniciativa legislativa $\mathrm{y}$ coincidencialmente cercano a una contienda electoral, de la cual ella obtuvo una alta votación. Su propuesta se convirtió en un índice alto de popularidad respecto del castigo de pena de muerte para los abusadores de menores.

Esta iniciativa como una crítica constructiva, no contó con un estudio científico de carácter social, no se hicieron estudios de los índices de criminalidad de ese delito, estudios sociológicos, psicológicos y psiquiátricos. Así mismo se deben analizar en profundidad las investigaciones que se han llevado a cabo en países extranjeros sobre esta problemática, como así mismo analizar concienzudamente las penas a imponer o los tratamientos de carácter preventivo y curativo, en centros especializados, de acuerdo con la sintomatología cuando hay trastornos mentales y anomalías psíquicas.

En otros países se procede a recluir a estas personas en centros especializados del Estado, como imposición de penas o medidas de control, con el fin de realizar un tratamiento con fines curativos y de resocialización.

El buscar la pena de muerte va en contravía de lo que busca un Estado Social de Derecho. Por lo tanto, esta iniciativa no es la mejor ya que no busca un resultado eficiente para la justicia penal y se convierte en un verdadero populismo punitivo y oportunismo 
electoral, pretendiendo demostrar que estas propuestas son duras y efectivas contra el crimen, porque cada partido político pretende ser el más eficiente en sus propuestas punitivas. En similares términos lo planteó la estudiante de la Facultad de Derecho en la Fundación Universidad del Norte, Cindy Paola Cotes Murgas, dentro de su trabajo "Populismo punitivo: incidencia actual en el contexto legislativo colombiano", en la página 64 de Actualidad Jurídica, la estudiante anotó: "por otro lado aparece en trámite una iniciativa legislativa realizada por el senador Roy Barreras en la que se propone cárcel inmediata a los conductores ebrios. Esta es apoyada por el ministro de transporte Germán Cardona, quien manifiesta el apoyo del gobierno a la iniciativa. "Una persona en estado de embriaguez es un asesino en potencia" dijo el Ministro. Agregó que es necesario "mandarles a los colombianos un mensaje de enorme responsabilidad, y decirles que conducir en estado de embriaguez da cárcel” (Cotes \& Fuentes, 2012).

Los problemas sociales de oportunidad, generan una alta sensibilidad por supuesto en la reacción de la sociedad, generando un afán e interés en el legislador, para una oportunidad de proyecto legislativo inmediata, a falta de estudios profundos, de análisis de la problemática, de investigación que busquen solucionar el problema social, sino solamente proponen la solución coercitiva, creando o aumentando la pena, incluso que no admiten libertad, con un efecto en la población carcelaria que aumenta cada día.

De los anteriores planteamientos necesariamente se derivan consecuencias del populismo que están relacionadas por supuesto, con el derecho penal, el proceso legislativo, hasta el punto, como lo he planteado en esta investigación, de tener efectos sobre la discrecionalidad del funcionario judicial. Dentro de la obra de la universidad 
EAFIT. Cuadernos de Investigación, en el área de derecho penal, Natalia Torres Cadavid en su tema "Populismo Punitivo en Colombia: una aproximación a la política legislativa de las recientes reformas de los delitos sexuales", nombra algunas consecuencias del populismo punitivo: "la primera de ellas, es cierta invasión del legislador en la esfera de la aplicación del derecho. Al inicial distanciamiento o incomprensión hacia sus propuestas o modo de proceder ha sucedido una activa política encaminada a privarles del margen de discrecionalidad que, debido a su pericia, gozaban en su correspondiente ámbito decisional". El Nuevo modelo penal de la seguridad ciudadana. Una guía para condenar, se le resta al juez experto en derecho penal y quien tiene relación directa con el caso, la autonomía necesaria para aplicar el derecho con justicia: la imposición de una pena que esté directamente relacionada con el desvalor del injusto, la culpabilidad y la necesidad de la pena del sujeto. --Así mismo refiere como otra consecuencia-la segunda se enuncia con facilidad: "ha ocurrido un gran empobrecimiento del debate parlamentario que impacta en los contenidos de la política criminal y el derecho penal..." (Torres, 2010)

Conclusión acertada para la actualidad pues la fuerza del populismo legislativo de oportunidad conmueve a diario las decisiones de los jueces en el área penal, afectando completamente la estructura del derecho penal, con efectos punitivos e índices altos de hacinamiento.

Una vez planteadas las teorías filosóficas como base teórica de este trabajo y haber expuesto las problemáticas más relevantes del Sistema Penal Acusatorio colombiano, en el tema siguiente, se hace un análisis de jurisprudencias de las altas 
cortes, en donde podemos ver la diversidad de criterios en las decisiones judiciales, casos que ilustran y corroboran lo dicho en precedencia, utilizando la metodología sociojurídica. 


\section{Capitulo III}

En este estudio comparativo de decisiones de las altas cortes, se contrastan diversos criterios, ya sea de desconocimiento del precedente judicial, la diversidad en la unificación de la jurisprudencia, la influencia de principios y reglas jurídicas, decisiones o sentencias amparadas con fuerza normativa; decisiones que se ciñen a los principios de razonabilidad y proporcionabilidad y decisiones basadas en el principio de supremacía de la constitución, como también decisiones influenciadas por un poder político, o decisiones basadas en criterios de los funcionarios judiciales. Es frecuente la diversidad de criterios, hasta el punto de tener que acudir a figuras de carácter constitucional, como la Tutela, o la última instancia como es el recurso de Casación. En estas instancias se encuentra que las decisiones no son uniformes, algunas son inanes; en algunos casos cuando hay salvamento de voto, podemos encontrar que este tiene en su manifestación, argumentos que cumplen una supremacía de derechos por encima de la decisión mayoritaria, la cual es, además, desfavorable al sentenciado.

Esto demuestra una incertidumbre muy amplia y desbordada de la discrecionalidad de las decisiones judiciales, como se verá en los casos siguientes.

\section{Análisis de jurisprudencias}

\section{Caso 1}

Este caso por decisión de la Sala Plena del Tribunal Superior, sala penal, mediante Acción de Tutela dentro de un delito de actos sexuales abusivos, por anteriores decisiones, este resuelve amparar el derecho al debido proceso y dejar sin efecto las decisiones judiciales anteriores, lo cual nos lleva a establecer relación directa con la 
problemática expuesta en esta investigación acerca de la Acción de Tutela, que a pesar de establecer la independencia judicial y principios de las autoridades judiciales, tiene un carácter excepcional como se expone en estos casos. Además, el presente tiene un antecedente con la interpretación jurídico normativa, ante la figura del preacuerdo motivo del debate y establecida en el sistema penal acusatorio colombiano.

Esta decisión del Tribunal y de los anteriores jueces conlleva a un debate y análisis de los métodos de interpretación y posturas del positivismo jurídico expuestas en el marco teórico, de autores como Hans Kelsen, Herbert L. Hart y otros.

FALLO DE TUTELA Rad. No. 69.478 del 24 de septiembre de 2013

MP. LEONIDAS BUSTOS MARTINEZ

Acción interpuesta por MARIA FANNY GOMEZ URBANO, contra la sala Penal del Tribunal Superior del Distrito Judicial de San Juan de Pasto y el Juzgado $4^{\circ}$ Penal del Circuito, siendo vinculados al trámite F-52 Seccional, Procuraduría 145 Judicial Penal II.

\section{- Fundamentos de la acción}

La accionante, promovió A.T. En contra de estos despachos judiciales al considerar vulnerados sus derechos fundamentales al Debido Proceso y la Igualdad; como consecuencia de las decisiones judiciales proferidas por estos despachos se improbó el PREACUERDO celebrado con la Fiscalía en el marco del proceso penal por el delito de "Actos Sexuales abusivos con menor de 14 años".

\section{Como Defectos de las providencias censuradas expuso:}

-- Habiendo celebrado preacuerdo con el ente acusador, dada la calidad de cómplice que le fue imputada por el delito de "actos sexuales abusivos con menor de 14 años" y 
recayendo la negociación exclusivamente en la dosificación de la pena, no era procedente con el argumento de violación del principio de legalidad por cuanto estimó que su participación en el punible lo fue como coautora.

.- Que los accionados no le impartieron legalidad máxime cuando la Fiscalía era la titular de la acción penal.

\section{Rta. Autoridades accionadas. -}

Tribunal Superior de Pasto. - solicitó tener en cuenta los fundamentos expuestos en su decisión.

Jdo $4^{\circ}$ PCto.- "Si bien la acción penal está radicada en cabeza de la fiscalía; también es cierto que el papel que asume el operador judicial no puede ser meramente administrativo, casi que de absoluta pasividad, en tanto que como sujeto encargado de velar por el respeto de los derechos fundamentales de las partes, si se encuentra con una protuberante contradicción entre la imputación jurídica y la realidad de los hechos como la que se ha suscitado en el presente caso - ello deviene en un quebrantamiento del Debido Proceso y los principios de estricta jurisdiccionalidad y tipicidad que amerita la intervención del Juez.”

Procuraduría: - indicó no compartir los argumentos de la Fiscalía, debido a que el núcleo fáctico del asunto conlleva a establecer que la participación de la demandante lo fue en calidad de coautora.

Víctima. - resulta claro que su participación en la conducta punible no fue en calidad de cómplice, sino de coautora. 


\section{- Consideraciones de la Corte}

1.- Dejar sin efecto las aludidas decisiones judiciales

2.- Verificación de requisitos de procedibilidad (generales y específicas)

3.- De la titularidad de la acción penal, LOS PREACUERDOS y su control por parte del Juez.

De acuerdo con el inciso $1^{\circ}$ del art. 66 del C.PP., en armonía con el art. $250 \mathrm{CP}$, "el Estado por medio de la FGN, está obligado a adelantar la acción penal...sic”

- En lo que concierne a la figura de los preacuerdos ha de señalarse que fue prevista con la finalidad de humanizar la actuación procesal y la pena, obtener pronta y cumplida justicia, activar la solución de conflictos sociales que genera el delito, propiciar la reparación integral de los perjuicios ocasionados con el injusto y lograr la participación del imputado en la definición de su caso; y por tanto la Fiscalía y el imputado o acusado podrán llegar a preacuerdos que impliquen la terminación del proceso.” (Art. 348).

4.- Según la reforma introducida con él AL 003/2002 el criterio que prohíja la Corte S.J, se ha demarcado en los siguientes términos:

"estructura un acto de parte que compete, de manera exclusiva y excluyente a la Fiscalía, desde donde deriva que la misma no puede ser objeto de cuestionamiento por el juez, las partes, ni los intervinientes, con la salvedad de que los dos últimos puede pueden formular observaciones en los términos del artículo 339." 
"Por tanto, cuando invalida la imputación, para que en su lugar sea complementada como en su opinión corresponde, está nada menos, que controlando materialmente la acusación."

\section{Dicho, en otros términos:}

"En estas condiciones, ha de entenderse que el control material de la acusación, bien sea por el trámite ordinario o por la terminación anticipada de la actuación, es incompatible con el papel imparcial que ha de fungir el juez en un modelo acusatorio.”

Recuérdese que el tópico que conllevó a improbar el preacuerdo celebrado entre MARIA FANNY GOMEZ BURBANO y la FGN consistió en la supuesta falta de correspondencia de la imputación fáctica con la jurídica, a partir de la valoración que la accionante imputada, no era en calidad de cómplice, sino de coautora.

Bajo este panorama, se concluye que las decisiones judiciales cuestionadas, en efecto desconocieron el derecho fundamental al Debido Proceso, por cuanto se profirieron al margen de la Filosofía, así como de las normas y la jurisprudencia vigente que regulan la limitación del Juez en ejercicio de la función del control de la terminación del proceso como consecuencia del preacuerdo.

RESUELVE. - amparar el derecho al Debido Proceso, en consecuencia, dejar sin efecto las decisiones judiciales proferidas.

ORDENAR. - al Juzgado de Conocimiento que en termino máximo de 10 días a partir de la notificación de éste fallo, efectúe el control de legalidad del preacuerdo celebrado entre la FGN y MARIA FANNY GOMEZ B. a la luz del ordenamiento Jurídico y la Jurisprudencia vigente para el caso. Sin perjuicio de los Derechos de las Víctimas. 


\section{Jurisprudencia Corte Constitucional}

\section{Sentencia C-738/08.- MP. MARCO GERARDO MONROY CABRA}

SEGUNDO. - INHIBIRSE de emitir pronunciamiento de fondo respecto de los numerales $7^{\circ}$ y $8^{\circ}$ del artículo 199 de la Ley 1098 de 2006, por las razones anotadas en esta providencia.

El fallo es contradictorio con numerosos fallos de jueces de instancia que desde ningún punto de vista permitía que esta conducta punible "acto sexual con persona puesta en incapacidad de resistir" se degradara a la calidad de COMPLICE.

\section{- Conclusión caso 1.}

\section{C.P.P Art. 351. C- MODALIDADES.}

Inciso $4^{\circ}$. "Los preacuerdos celebrados entre Fiscalía y acusado obligan al juez de conocimiento, salvo que ellos desconozcan o quebranten las garantías fundamentales".

.- Si esta institución jurídica obliga al Juez, el proceso no tenía por qué haber llegado hasta el amparo de la tutela.

.- Si la norma no prohíbe expresamente a la Fiscalía "DEGRADAR" éste tipo de conductas de AUTOR, COAUTOR a cómplice, ninguna lógica conllevaría a que los jueces de instancia hubieran negado el preacuerdo firmado entre el imputado y la FGN.

Se hace un esguince a la norma “Art. 199-7 de la Ley 1098/2006”, en el sentido que el PREACUERDO realizado entre la Fiscalía y la acusada, “per se”, no estaba expresamente otorgándole un rebaja de pena; pero sí tácitamente al 
calificar una conducta con todos los EMP para imputarle el cargo como coautora, lo moduló o degradó a COMPLICE, lo cual en síntesis implicaba rebaja de pena a imponer.

Para nada se mencionó el Artículo 199 - 7 de la Ley 1098/06

7- No procederán las rebajas de pena con base en los "preacuerdos y negociaciones entre la fiscalía y el imputado o acusado", previstos en los artículos 348 a 351 de la Ley 906 de 2004.

2. . No sigue una metodología respecto a las normas que están llamadas a resolver el caso.

\section{ARTICULO 209. ACTOS SEXUALES CON MENOR DE CATORCE} AÑOS. <Artículo modificado por el artículo 5 de la Ley 1236 de 2008 . El nuevo texto es el siguiente:> El que realizare actos sexuales diversos del acceso carnal con persona menor de catorce (14) años o en su presencia, o la induzca a prácticas sexuales, incurrirá en prisión de nueve (9) a trece (13) años.

\section{ARTICULO 211. CIRCUNSTANCIAS DE AGRAVACION PUNITIVA. <Artículo} modificado por el artículo $\underline{7}$ de la Ley 1236 de 2008. El nuevo texto es el siguiente:> Las penas para los delitos descritos en los artículos anteriores, se aumentarán de una tercera parte a la mitad, cuando:

1. La conducta se cometiere con el concurso de otra u otras personas.

2. El responsable tuviere cualquier carácter, posición o cargo que le dé particular autoridad sobre la víctima o la impulse a depositar en él su confianza. 


\section{Caso 2}

Aquí acudimos a un recurso de Casación, Sala penal de la Corte Suprema de Justicia que resuelve frente al quantum punitivo al imponer una pena por una aceptación de cargos, por el delito de tráfico de estupefacientes, frente a la inconformidad de la defensa, la Corte casa parcialmente, pero cuando lo hace, la persona ya ha cumplido la pena, por ello se torna inane la decisión. En este caso nos ubicamos en tres de las problemáticas expuestas aquí. Una es en cuanto a los efectos de los allanamientos, la segunda, a las diversas interpretaciones de la norma, como de los jueces y magistrados. La tercera problemática, asunto que se refiere a la discrecionalidad judicial, que tienen los jueces en su decisión, lo que se ha plasmado en esta investigación por García Amado y Bonorino \& Peña y demás teorías de la interpretación.

Radicado No. SP.11726-2014

MP. JOSE LEONIDAS BUSTOS MARTINEZ

Recurso de Casación

\section{Antecedentes}

La cuestión fáctica -ocurrida en Bogotá-, a que se contrae la actuación, fue reseñada por el Tribunal de la manera siguiente:

El 2 de marzo de 2009 aproximadamente a las 8 y 40 de la mañana, ÉDGAR ALFONSO MORENO MORENO fue capturado en la carrera $8^{a}$ con calle 14 de esta ciudad por llevar 2,2 gramos de cocaína y 51.8 gramos de marihuana en una bolsa plástica oculta en la pretina del pantalón. 
La imputación se efectuó por el delito de tráfico, fabricación o porte de estupefacientes, en la modalidad $<>$, descrito y sancionado en el artículo 376, inciso $2^{\circ}$ del Código Penal, con la modificación punitiva de que trata el artículo 14 de la Ley 890 de 2004, cuyos cargos fueron aceptados por el implicado con la asistencia y en presencia de su defensora. El juez verificó la legalidad de las actuaciones, que el imputado aceptó los cargos de manera libre, consciente, voluntaria, sin presión ni apremio de ninguna índole, debidamente informado, asesorado por su defensora pública, y sin que se advirtiera la violación de sus derechos fundamentales, después de lo cual declaró legalmente formulada la imputación y la remisión de lo actuado al funcionario competente para la emisión de la sentencia correspondiente, no sin antes disponer la libertad inmediata del indiciado, toda vez que la Fiscalía desistió de la solicitud de imposición de medida de aseguramiento. Subrayado fuera del texto.

En cumplimiento de lo dispuesto en el artículo 293 del estatuto procesal penal (Ley 906 de 2004), el 17 de abril de 2009, el Juez $7^{\circ}$ Penal del Circuito de Conocimiento, después de verificar que el allanamiento de los cargos endilgados por la Fiscalía obedeció a una decisión informada, consciente, libre y espontánea del imputado, bajo el asesoramiento de la defensa, decidió impartir aceptación al allanamiento.

El 17 de abril de 2009, el Juzgado condenó a EDGAR ALFONSO MORENO MORENO, a las penas principales de treinta y nueve (39) meses y seis (6) días de prisión, y multa en cuantía de 4.48 salarios mínimos legales mensuales vigentes. Subrayado fuera del texto 
Contra este fallo la defensa recurrió en apelación, tras mostrar inconformidad con el quantum punitivo a partir del cual se individualizó la pena, pues, según argumentó, el Juez de Garantías advirtió que se le impondría la pena mínima de 64 meses de prisión y pese a ello en la sentencia se fijó en 70 meses. Discutió igualmente que no se le hubiera concedido el $50 \%$ de rebaja de pena por aceptación de cargos, sino que aplicó el 44\% argumentando que fue capturado en situación de flagrancia y la contundencia de la evidencia recaudada; aún si no aceptara cargos, la sentencia habría de ser condenatoria.

Con fundamento en lo anterior la defensa solicitó la imposición de la pena mínima y reconocerle la rebaja del $50 \%$ por allanarse a cargos en la audiencia de FI y suspenderle condicionalmente la ejecución de la pena.

Tribunal mediante pronunciamiento 17 septiembre de 2009, accedió parcialmente a las pretensiones del recurrente, individualizó la pena a partir de 68 meses e prisión, la que a su vez rebajó en el $50 \%$.

No le concedió, sin embargo, la suspensión condicional de la ejecución de la pena, pues, aunque advirtió el cumplimiento del presupuesto objetivo, no aconteció igual con el de índole subjetiva.

Estimó al respecto que si bien <no obra prueba en el expediente que demuestre que el procesado es consumidor de las sustancias estupefacientes que portaba y en caso de ser cierto, esto no excluye que los estupefacientes tuvieran como fin su 
comercialización, pues recuérdese que las dos superan en más del doble la dosis personal, y la cocaína hallada no estaba guardada en un solo contenedor sino empacada en diez (10) papeletas de lo que se desprende que estaban destinados a su enajenación>.

Añadió que < la conducta punible realizada deja ver que el autor es una persona carente de escrúpulos y evidencia una gran deficiencia de valores y principios necesarios para la convivencia pacífica y las relaciones armoniosas con la sociedad que deben estar caracterizadas por el respeto de los derechos ajenos o colectivos como la salud pública para no anteponer intereses privados indebidos como el egoísmo y la avidez de dinero>

Decidió condenar a EDGAR ALFONSO MORENO MORENO a 34 meses de prisión y negar el subrogado de suspensión condicional de la ejecución de la pena.

De la demanda de casación. El defensor alega que Tribunal incurrió en Violación directa de la Ley sustancial por aplicación indebida del artículo 376-2 del Código penal a la cual arribó debido a un mal entendimiento del principio de antijuridicidad material. Considera que, en el fondo, esa inocencia de su representado por no afectación de la salud pública, < la sostuvo la fiscalía desde la primera audiencia en que se legalizaron la aprehensión del indiciado y de la sustancia>, y seguidamente transcribe la manifestación de la Fiscalía de desistir de la solicitud de imposición de medida de aseguramiento en contra del imputado.

Anota que la realidad procesal, al contrario de lo aseverado por el Tribunal, muestra al acusado como un hombre todavía joven, con 39 años de edad, de estudios 
universitarios, que vive con su anciana madre, habla varios idiomas, y carece de antecedentes, lo que "movió al fiscal, en la primera audiencia preliminar, a poner de presente, además, que exhibía arraigo y que de él debía predicarse que era CONSUMIDOR o un ADICTO, a quien, por tanto, en su oportunidad debería PRECLUÍRSELE este caso"

\section{- Conclusión caso 2}

1. Corte Suprema de justicia CASA PARCIALMENTE. - concede al acusado la suspensión condicional de la ejecución de la pena. -

Así las cosas, si los hechos ocurrieron el 2 de marzo de 2009 y la condena fue a 34 meses de prisión, para el momento que sale el fallo de la CSJ., la persona ya ha pagado la totalidad de la pena. Se torna inane la decisión.

2. Si el sistema penal es de corte adversarial como lo dice la ley y la jurisprudencia, porque se desatendió el dicho de la Fiscalía en la audiencia de imputación como se señaló en el numeral $9^{\circ}$ de éste escrito.

3. Algunos jueces en todas las jerarquías están fallando según su capricho y no de acuerdo con lo probado en el proceso, confundiendo la autonomía e independencia judicial con la arbitrariedad.

4. Si se lee cuidadosamente el art. 63 del estatuto de las penas, el sentenciado cumplía con los requisitos que la Ley exigía para la concesión del subrogado de “suspensión condicional de la ejecución de la pena”.

5. La Corte hace un gran esfuerzo argumentativo e interpretativo de la dogmática, de los textos legales (ley 30 de 1986, hasta llegar art. 376 ley 599 de 
2000 y sus reformas L.1453/11), definiendo la antijuridicidad material, el principio de lesividad art. 11 Cp., radicado 34093 de la CSJ sobre principio de lesividad; menciona constitución, de la Jurisprudencia de la Corte Constitucional C-574/11, C/491/12 sobre dosis personal; menciona la interpretación histórica, sistemática, teleológica, exegética, en total (84) folios para producir un fallo extemporáneo.

6. Aun siendo un fallo donde el MP. Es el Dr. JOSE LEONIDAS BUSTOS, no hay una metodología o una especie de "protocolo" o parámetros a los cuales se deban ceñir las sentencias de los jueces de la Republica sin que se afecte su autonomía e independencia.

\section{Caso 3}

Este caso está incurso en la problemática planteada en cuanto a la discrecionalidad de los Magistrados del Tribunal y de la Corte Suprema de Justicia, en cuanto a la disparidad de cr4iterios denegando y concediendo la libertad a través de acciones constitucionales, como es el caso del Habeas Corpus, en materia penal. Dos aspectos pueden desprenderse de esta dualidad de criterios, la falta de conocimiento suficiente que generó en este caso prolongar la libertad y como consecuencia incrementar el hacinamiento carcelario a causa de la privación de la libertad.

Así, este caso tiene estrecha relación con el marco teórico expuesto, en cuanto tiene que ver con la interpretación constitucional respecto al derecho a la libertad y como consecuencia, en apartes de lo expuesto por Duncan Kennedy, ante inconsistencias de la decisión judicial o la falta de mayor conocimiento de los jueces. Estudios que relacioné en la primera parte de esta investigación, donde Benítez \& González (expuesto por Cesar Rodríguez, cuando refiere de 
Duncan Kennedy), afirman que los jueces en sus fallos utilizan un discurso de la aplicación mecánica del derecho.

\section{HABEAS CORPUS}

Rad. No. 39804 del 30 de agosto de 2012

Magistrado: JULIO ENRIQUE SOCHA SALAMANCA

Acción de Habeas Corpus.

\section{- Motivo del pronunciamiento}

Resuelve impugnación contra la decisión de 22 de agosto de 2012 mediante la cual el TS del Distrito Judicial de Cali, negó la Acción de Habeas Corpus.

\section{- Antecedentes procesales}

1. "El 21 de agosto del año 2012, por conducto de su abogado EDMUNDO ANIBAL ARTEAGA NARVAEZ promueve acción de Habeas Corpus ante la sala Penal del TS de Cali, con base en que en el proceso que se le sigue por el delito de “corrupción de alimentos ante el Juzgado $5^{\circ}$ P. Cto., desde la fecha de formulación de la acusación, ocurrida el 18 de enero de 2012, transcurrieron más de 120 días sin que se iniciara la audiencia de juzgamiento, continuando privado de la libertad en forma ilegal, pese a que recurrió ante el J.C. Garantías competente para que se le otorgara ese derecho por el vencimiento de los términos, (Art. 317-5L.906, modificado por L.1142/07 y 1453/11 artículos 30, 31 respectivamente).

2. El 29 de junio de 2012 elevó solicitud de libertad la cual le correspondió al Juez 17 P. Municipal de Cali quien fijó como fecha para realizar la audiencia el 18 de 
Julio a las 10:00 horas, la que no se pudo llevar acabo porque no se presentó ni el Fiscal, tampoco el acusado debido a que el INPEC no lo trasladó a la diligencia.

3. El 15 de agosto de 2012 a las 14:00 horas, fue señalada por el J. C. garantías como nueva fecha para llevar a cabo el trámite, el cual no se pudo llevar a cabo porque en esta oportunidad el Fiscal no acudió a la diligencia, motivo que llevó al juez a postergar para el día 31 de agosto la audiencia para decidir sobre la libertad por vencimiento de términos. (Es decir 62 días para resolver solicitud L.V.T. art. 317-5). 4. Con el fin de verificar los fundamentos del mecanismo constitucional, la magistrada del T.S de Cali a la que le correspondió el amparo, ordenó la práctica de inspecciones a los expedientes contentivos del proceso penal.

- Constata que el accionante fue capturado el 20 de septiembre de 2011.

- Que la Fiscalía radicó escrito de acusación 18 de noviembre de 2011

- Que el 18 de enero de 2011 se formuló la acusación

- El 9 de marzo de 2012 se instaló la audiencia preparatoria, la cual fue suspendida para tramitar recurso de apelación que fue resuelto por el Tribunal el 19 de abril de siguiente, revocando y ordenando la admisión de unos testimonios. (40 días tramite recurso)

- El 13 de Julio de 2012 se instaló formalmente la audiencia de Juicio, en su desarrollo se avanzó en los alegatos de apertura y la práctica de unos testimonios. (recuérdese que la acción de Habeas Corpus, se presentó el $\mathbf{1}^{\circ}$ de agosto de 20129 
- Debido a la inasistencia de unos testigos la audiencia fue aplazada por solicitud de la Fiscalía, fijándose por el Juez de conocimiento el día 30 de octubre de 2012 para reanudar el debate oral.

5. Constatado lo anterior, la magistrada del T.S. de Cali, mediante decisión del 22 de agosto negó la acción de Habeas Corpus.

6. Como fundamento de su decisión y luego de precisar desde el punto de vista teórico cuándo puede predicarse una "Privación ilícita de la Libertad" para que sea admisible la acción constitucional invocada, la A Quo aseguró que a la solicitud de libertad se le ha dado "un trámite oportuno" y dentro de “términos prudenciales", el juez al que compete decidir ha señalado las fechas para ello, sin poder adelantar la respectiva audiencia por las causas que indicó el actor, no obstante lo cual está programado resolver la pretensión para el próximo 31 de agosto, cuando ya se ha dado inicio al juicio oral, de suerte que " por tratarse de supuestos de hecho que no son idénticos, frente al asunto en estudio no es dable aplicar la providencia que sobre éste tema profirió la Corte Suprema de justicia - sala Penal”.

7. Es de resaltar lo que a párrafo seguido indicó la honorable C.S.J, como se lee: "luego en tres párrafos subsiguientes de las consideraciones que deberían corresponder a la decisión de la Corte anteriormente aludida, la magistrada transcribe entre comillas fragmentos de una providencia que no sólo no fue emitida por esta Sala, sino que de acuerdo con la nota de pie de página allí apuntada, pertenecería a un pronunciamiento de un magistrado del Tribunal Superior de 
Bogotá y que además por su contenido resulta ser por completo ajena a la situación debatida...sic"

Y remata las consideraciones aseverando que como para cuando se intentó la presente acción pública (21 de agosto) en el juzgado Quinto Penal del Circuito de Cali ya se había dado inicio al juicio oral (13 de julio), "ha fenecido como lo sostuvo la jurisprudencia que antecede, la presunta ilegalidad que afecta la libertad provisional del accionante, argumentada como causal 5 del artículo 317 de la ley 906 de $104 "$

\section{- Consideraciones}

1. En éste acápite, el magistrado que resuelve la impugnación hace alusión al artículo $7^{\circ}$, numeral 6 de la $\mathrm{CADH}$, derecho de toda persona privada de la libertad para acudir ante un juez o tribunal competente para que decida sin demora sobre la legalidad de su arresto o detención; así mismo a la sentencia C/496/94 respecto de la garantía del habeas Corpus, reconocido en el artículo 7-6 de la $\mathrm{CADH}$, "puesto que ésta es la forma de realizar el principio de efectividad de los medios procesales destinados a garantizar los Derechos Humanos".

2. También hace alusión a la Ley 1095 de 2006 mediante la cual se reglamentó el artículo 30 de la constitución Política, y el objeto de ésta garantía y mecanismo de Habeas Corpus - destinada a ser ejercida I) cuando la persona es privada de la libertad con violación de Garantías Constitucionales o Legales, II) cuando la privación de la libertad se prolonga ilegalmente. 
3. La mora del Juez de Control de Garantías para que decidiera si se configuraba o no la causal de libertad invocada art. 317-5 C.P.P., habilita la posibilidad de recurrir al juez de habeas Corpus para que el mismo estudiara los fundamentos de la solicitud. 4. Art. 154-8 de la Ley 906/04, se tramitan ante el J. C. Garantías las "peticiones de libertad que se presenten con anterioridad al anuncio del sentido del fallo”.

5. Art. 160/L.906, modificado por art. 48 L.1142/07. “cuando deban adoptarse decisiones que se refieran a la libertad provisional del imputado o acusado el funcionario judicial dispondrá máximo de tres días hábiles para realizar la audiencia respectiva”.

6. La anterior recapitulación que el Juez 17 Penal Municipal de Cali, incurrió en una vía de hecho por defecto procedimental absoluto, al negar el legítimo acceso a la Justicia con la pretermisión de los términos lo cual habilita la intervención de los términos, lo cual habilita la intervención del juez constitucional mediante acción de Habeas Corpus.

7. Art. 317 C.P.P. cuando transcurridos 120 días ininterrumpidos desde la formulación de la acusación no se ha iniciado la audiencia de juzgamiento.

8. Se encuentra plenamente acreditado que en el asunto penal al que se refiere la acción de habeas Corpus desde que se formuló la acusación 18 de enero de 2012, hasta la fecha de inicio de audiencia de juicio oral 13 de julio de 2012, transcurrieron 176 días, lapso que supera ampliamente los 120 días señalado en la norma, como condición sustancial para la estructuración de la Libertad invocada. 
9. “Impera señalar que en éste asunto no se acreditó que la mora en el inicio del juzgamiento se hubiese debido a la configuración de un hecho externo y objetivo determinante de fuerza mayor, sin que dentro de tal categoría pueda concebirse el tiempo que demoró suspendida la audiencia preparatoria para tramitar la apelación formulada por uno de los intervinientes (el agente del ministerio público). subraya y negrilla fuera del texto.

\section{Resuelve}

1. Revocar auto del 22 de agosto de 2012 de magistrada T.S. Cali

2. Declarar procedente el amparo constitucional invocado y otorgar la libertad inmediata.

\section{- Conclusión caso 3}

1.- Se privilegia el Derecho a la Libertad.

2.- Termina una práctica generalizada y reprochable de jueces y magistrados que se congraciaban con la Fiscalía para negar la libertad por esta causal 317-5. Aduciendo que al proceso se le había dado "un trámite oportuno" y dentro de "términos prudenciales".

3.- Concede la libertad aun habiéndose dado inicio a la audiencia de Juicio Oral, lo cual se hace extensiva a libertad por vencimiento del numeral $4^{\circ}$ ibídem.

4.- Jueces y magistrados dentro de su autonomía e independencia, no están haciendo una argumentación juiciosa de sus decisiones, tornándose en fallos arbitrarios donde no aplican el derecho (Ley) ni reconocen los Derechos del ciudadano. 


\section{Caso 4}

En este caso que se reseña, con decisión del Tribunal Superior de Bogotá, sala penal, con salvamento de voto, nos ilustra que este tiene en su manifestación argumentos que cumplen una supremacía de derechos fundamentales por encima de la decisión mayoritaria la cual es desfavorable al sentenciado. Este fenómeno se podría enmarcar dentro de la "Teoría de la Argumentación Jurídica" planteado por Alexy, ya que este autor afirma que los principios son mandatos de optimización y se conceden con la interpretación de los derechos constitucionales.

En el marco teórico de esta investigación nos ilustra por otra parte, la problemática enunciada en el capítulo II que se refiere a la crítica de la educación, que tiene relación con la formación, la actualización y modernización del derecho penal, ya que quien hace salvamento de voto refiere que la decisión mayoritaria se basa en principios caducos y revaluados entre otros aspectos contrarios al salvamento de voto que basa su decisión en salvaguardar principios de nuestra actual Constitución Política.

Magistrado Expositor: Luis Mariano Rodríguez Roa

Radicación: 11001600002820080411402

Procedencia: Juzgado 19 Penal del Circuito de Conocimiento

Procesado: Jhon Jairo Fontalvo Zambrano

Delito: Homicidio y otro

Motivo: Apelación sentencia ordinaria

Decisión: Revoca parcialmente

Aprobado: Acta No. 095 A 
Fecha y hora: Veintisiete (27) de julio de 2010. 4:00 p.m.

\section{- Asunto}

El recurso de apelación interpuesto contra el fallo proferido por el Juzgado 19 Penal del Circuito de Bogotá con Función de Conocimiento, a cargo de la Dra. Aída Beatríz Díaz Muñoz, a través del cual absolvió a Jhon Jairo Fontalvo Zambrano de los cargos de homicidio y porte ilegal de armas de fuego.

\section{- Consideraciones de la Sala}

2.1 Ateniente a la responsabilidad penal, la sentencia impugnada enuncia en su motivación que la Fiscalía no logró demostrar "en grado de certeza" que el acusado Jhon Jairo Fontalvo Zambrano fuera el autor del homicidio, en la medida que los dos agentes de la Policía que le dieron captura afirman no constarles que Fontalvo fue quien efectuó los disparos homicidas, y su captura tan sólo obedeció al hecho de portar el arma de fuego y haber realizado unos disparos cuando era perseguido.

Pierde de vista la juez las reglas de la experiencia y el sentido común que los agentes del orden por lo general son llamados o llegan al lugar de los acontecimientos después de que ha ocurrido el hecho delictuoso y por esta elemental circunstancia es imposible que les pueda constar directamente su ejecución para plasmarlo en sus testimonios.

Es necesario advertir igualmente que en el plano de la dogmática la convicción del juez sobre la responsabilidad de un procesado no es la que corresponde al conocimiento propio de la certeza absoluta, y que deba soportarse en rigorismos o extremos probatorios como el que extraña la juez de instancia, sino una certeza racional en grado relativo pero suficiente que persuada y dispense al fallador el "conocimiento más allá de 
toda $d u d a "$, que al final de cuentas es la exigencia normativa que el artículo 381 de la ley instrumental demanda sobre tal aspecto subjetivo para cimentar un fallo de condena.

No sin razón la Sala de Casación Penal de la Corte tiene sentado sobre tal grado de conocimiento y a manera de directriz a la judicatura:

“7. Tal como ha sido expuesto por la Sala (2), la convicción sobre la responsabilidad del procesado corresponde a un estadio del conocimiento propio de la certeza racional (3) (si ocurre A, entonces, necesariamente acontece B) y, por tanto, relativa, dado que la certeza absoluta resulta imposible desde la perspectiva de la gnoseología en el ámbito de las humanidades e inclusive en la relación sujeto que aprehende y objeto aprehendido.

En consecuencia, sólo cuando no se arriba a dicha certeza relativa de índole racional ante la presencia de dudas sobre la materialidad y existencia del delito investigado o sobre la responsabilidad del acusado, siempre que, en todo caso, dichas dudas tengan entidad y suficiencia como para crear incertidumbre sobre tales aspectos posibles en cada caso concreto, no con elementos de convicción ideales o imposibles, ahí, en tal momento, es posible acudir a la aplicación del principio in dubio pro reo, esto es, resolver la vacilación probatoria en punto de la demostración de la verdad, a favor del acusado.

Así las cosas, no exigir que la demostración de la conducta humana objeto de investigación sea absoluta resulta conforme la teoría del conocimiento, pues ello siempre será, como ya se dijo, un ideal imposible de alcanzar, como que resulta frecuente que variados aspectos del acontecer que constituyó la génesis de un proceso 
penal no resulten cabalmente acreditados, caso en el cual, si tales detalles son nimios $\boldsymbol{o}$ intrascendentes frente a la información probatoria ponderada en conjunto, se habrá conseguido la certeza racional requerida para proferir fallo de condena"

Acorde con el concepto y línea jurisprudencial de la Sala de Casación Penal de la Corte acerca de la flagrancia a partir de la sentencia del $1^{\circ}$ de diciembre de 1987 como "evidencia procesal" derivada de la oportunidad que una o varias personas han tenido de presenciar la realización del hecho punible o de apreciar a su ejecutor con objetos, instrumentos o huellas que indiquen fundadamente su participación en el delito, dos presupuestos esenciales deben verificarse como requisitos: “...la actualidad, esto es, la presencia de las personas en el momento de su realización del hecho o momentos después, percatándose de él y en segundo término la identificación o por lo menos individualización del autor del hecho..."

Estos presupuestos estructurales de la evidencia procesal a juicio de la Sala Mayoritaria se materializan y proyectan en el sub judice a partir del señalamiento de quienes en el lugar del hecho de sangre orientaron a los representantes de la autoridad (requisito de actualidad) de la dirección que había tomado el homicida, capturándose como tal a John Jairo Fontalvo Zambrano según las condiciones de incriminación que quedan analizadas y que los representantes de la autoridad plasman en sus testimonios, hechos relevantes que guardan sincronía y conexidad con lo relatado por el testigo Jhonier Rodrigo Piedrahita Gamboa en cuanto a las características que de la fisionomía del homicida reporta en su atestación: alto, de tez morena y acento costeño, las cuales se avienen a las del acusado Fontalvo Zambrano y su conducta asumida (presupuesto de 
individualización), y que con igual asidero de convergencia y univocidad imprimen respaldo probatorio los testimonios de los representantes de la autoridad quienes si bien no presenciaron el acto homicida, oyeron los disparos y se hicieron presente de inmediato en el lugar del hecho, para con la colaboración de los ciudadanos percibir y capitalizar los pormenores que condujeron la captura.

Las suposiciones del juzagado carecen de asidero y la incertidumbre que le imprime y resuelve la propia falladora con el criterio de la duda, no puede constituir fundamento procesal que desvirtúe la dialéctica de las probanzas que quedan analizadas en conjunto.

\section{- Decisión}

Como corolario de todo lo expuesto y aún con la falencia investigativa de la Fiscalía ya anotada, mal puede la Sala Mayoritaria en el plano lógico jurídico compartir la incertidumbre que la falladora de instancia imprime a las suposiciones que plantea como premisa explicativa de la conducta de Fontalvo, de adverar que estaba armado y hasta le disparó a los agentes de Policía que lo perseguían, pero por causas hipotéticas distintas al homicidio, las cuales adolecen de asidero y verosimilitud.

Más lógica y sentido se decanta del acervo probatorio reseñado en precedencia, que en su contexto conlleva a la certeza racional de la responsabilidad del acusado, al asumir éste los comportamientos graves que dicha prueba acredita y que, aunque indirecta es clara y diáfana en dispensar como consecuencia la inferencia de su nexo y relación causal con el homicidio que se investigó, destruyendo no sólo la presunción de inocencia que le asiste como derecho, sino todo asomo de incertidumbre. 


\section{- Salvamento de voto}

El legislador en aras de salvaguradar el principio constitucional de la presunción de inocencia, consagrado en el artículo 29 de la Carta Política y de nítido desarrollo normativo en el artículo 7 de la ley 906 de 2004, vincula o supedita la procedencia del fallo de carácter condenatorio, al tenor de los artículos 16 y 381 ibídem, a la práctica o introducción en forma legal, regular y oportuna de medios de prueba que valorados con apego a los derroteros de la sana crítica conduzcan al conocimiento más allá de toda duda en relación con la conducta punible objeto de la acusación y tratándose de la responsabilidad penal, a tal punto, que en el evento de echarse de menos uno de tales requisitos el pronunciamiento conclusivo de las instancias no puede ser diverso a la absolución.

Por otra parte, a una providencia de esa última naturaleza referida se arriba, bien porque el juzgador encuentra acreditada en la actuación respectiva la inexistencia del delito, su falta de antijuridicidad o de culpabilidad, ora porque la persona acusada y procesada resulta ajena a su realización; pero además, en hipótesis que anticipo es la configurada en el presente asunto, en aplicación del postulado del in dubio pro reo, esto es, ante las dudas insalvables en torno a alguno de dichos hitos.

Estas dudas surgen en concreto, de la deficiente labor de la Fiscalía no sólo en la investigación sino también con mayor dramatismo en el caso del juicio oral, público y concentrado, oportunidad esta última en la cual se exteriorizó un persistente comportamiento omisivo que generó la orden impartida en el fallo del a quo de expedir copias con destino a una eventual investigación disciplinaria. 
Ciertamente, la afirmación anterior está soportada en la circunstancia de que el representante de la Fiscalía en este proceso, apegado a esquemas caducos y revaluados soslayó el aseguramiento y práctica de pruebas técnicas que habrían obviado la especulación a la que necesariamente debe acudir la Mayoría de la Sala, afirmado sea con respeto, para suplir los vacíos demostrativos en punto a la autoría del delito de homicidio.

En efecto, en inmediaciones del lugar del homicidio fue incautada o recuperado una pistola cuya detentación se le atribuyó al acusado; sin embargo, a pesar del cuidadoso embalaje de la que fue objeto, de la que cuenta el uniformado Henry Alexis Ramírez Giraldo en el testimonio rendido bajo juramento en el juicio oral y público (cd. 2, a partir 11:55, en especial 43:04), nada fue dispuesto para verificar la existencia en ella de huellas dactilares, esto es, con el propósito de vincularla sin remisión a dudas al proceso FONTALVO ZAMBRANO.

Ahora bien, esta constatación habría resultado prescindible, inclusive superflua, si el acusado hubiera sido sorprendido en la tenencia material del arma.

Mal pueden pasar inadvertidas dos importantes circunstancias que menguan la contundencia y mérito incriminatorio de dicho aserto.

Ahora bien, esta endeble prueba de cargo se pretendió robustecer sin éxito con el testimonio de Jhonnyer Piedrahita Gamboa, presencial del homicidio, quien en las preguntas directas de la Fiscalía y en el contrainterrogatorio de la defensa finalmente admitió la imposibilidad que tenía para reconocer el autor del homicidio, más aún para señalar en tal sentido al acusado presente en juicio; agresor de quien simplemente señaló que se trataba de persona de alta estatura, "moreno" y al parecer de "acento costeño". 
Estas gaseosas y etéreas referencias le brindan fundamento a la mayoría de la Sala para corregir que dichas características corresponden precisamente a la fisionomía de FONTALVO ZAMBRANO (cd. 3), lo cual puede ser cierto admito, pero sin que desde mi perspectiva pueda atribuírsele la ejecución del delito pues es sabido también del testimonio Vargas Ramírez que el sector se caracteriza por la presencia de muchos trabajadores provenientes "de la costa" (cd. 2; 37:06).

En el temor que refirió el representante de la Fiscalía del mencionado presencial de los sucesos, así como de la actitud del mismo en la audiencia pública se dedujo otro aspecto que corroboró la prueba de cargo. No obstante, nada permite inferir que la misma proviniera del acusado, de sus allegados o amigos, y sin que pueda pasarse por alto, conforme a la constancia de la defensa en la apertura del juicio oral que el declarante Piedrahita Gamboa no existía dato alguno en las diligencias acerca de su domicilio.

En síntesis, concluyo con respeto, la prueba indicaría que invoca la Mayoría para la condena, de tenerse por plural, surge en todo caso contingente, por lo tanto, insuficiente en mi opinión para forjar el convencimiento reivindicado normativamente para la condena $y$, en este orden de ideas estimo que el fallo absolutorio de primera instancia debió ser confirmado.

Firmado por el Magistrado MARCO ANTONIO RUEDA SOTO

\section{- Conclusiones caso 4}

- 1 - Se desconocen las garantías constitucionales.

- 2- Se desconoce la figura del In Dubio Pro Reo.

- 3- Se interpreta de manera incorrecta el principio de inmediación. 
- 4- Se mantienen esquemas caducos y revaluados, con tesis ya no predicables.

- 5- Se toma una decisión sobre criterios jurisprudenciales remotos a costa de proferir una sentencia condenatoria.

- 6- Se desconocen los presupuestos de la Constituciòn Polìtica de Colombia de 1991. 


\section{Conclusiones}

La autonomía e independencia judicial viene siendo malinterpretada por algunos jueces de la república, hasta confundir esta facultad constitucional con la arbitrariedad, lo cual ha generado impunidad, pérdida de credibilidad del ciudadano en la justicia, hechos de corrupción, el Estado ha tenido que pagar millonarias indemnizaciones por fallas en el servicio, por errores judicial o deficiente administración de la justicia.

Hace falta que los jueces reciban capacitación en todos los niveles jerárquicos sobre: ética - valores, filosofía del derecho, argumentación jurídica, dogmática jurídica, actualización normativa, cultura general que garanticen a los ciudadanos unos estándares - protocolos - mínimos de calidad que deba cumplir una decisión judicial para que sea aceptada por las partes y por la misma sociedad, que garanticen de manera efectiva el derecho de acceso efectivo a la administración de justicia que permitan recuperar la confianza de los ciudadanos en el aparato judicial.

No existe una política criminal seria, coherente por parte del estado para hacer efectivos los derechos constitucionales, obligaciones, libertades de los ciudadanos y los bienes jurídicos tutelados por la ley; el derecho penal pasó de ser la "Ultima Ratio” a ser la " $1^{a}$ y única ratio", lo que se evidencia con las reformas legislativas a la Ley 906/04 y $599 / 00$, es que incrementan penas y reducen beneficios a los investigados y penalmente 
responsables y auspician el creciente hacinamiento carcelario, por el sinnúmero de normas.

La implementación del Sistema penal acusatorio en Colombia (AL 003/02, Ley 906/04) originado en la creciente congestión de los despachos judiciales, no ha respondido a las expectativas del Estado y de los ciudadanos de impartir y obtener pronta y cumplida justicia que garanticen la convivencia pacífica, los derechos fundamentales de la víctima (verdad, justicia, reparación) y acusado a un juicio (público, oral, concentrado, contradictorio) sin dilaciones injustificadas. No han tenido aplicación suficiente las instituciones jurídicas de: preacuerdos, negociaciones y principio de oportunidad.

Se ha edificado la falacia, que la solución para el problema del hacinamiento carcelario que afronta el país se combate con la construcción de un elevado número de centros carcelarios. Se dejan de lado aspectos estratégicos como: la educación al niño, al ciudadano sobre deberes y derechos; una política criminal que involucre a los distintos estamentos del estado y de la sociedad Colombiana y un tratamiento penitenciario, que respetando la dignidad humana, garanticen el cumplimiento de las funciones de la pena de: retribución justa, prevención general, especial y la resocialización del delincuente, así como la protección del condenado.

La preceptiva constitucional y legal de la autonomía e independencia judicial art. 228, art. $5^{\circ}$ Ley 270/96 estatutaria de la administración de justicia; su sumisión, única y 
exclusivamente al imperio de la ley art. 230 CP, la consagración de la jurisprudencia como un criterio auxiliar para el ejercicio de su función jurisdiccional, han fomentado inseguridad jurídica y trato desigual a los ciudadanos, según el criterio que adopte la instancia judicial y han significado un desgaste inoficioso de la doctrina vertida por la Corte Constitucional y la Corte Suprema de Justicia en su finalidad de unificar la Jurisprudencia en materia penal. Art. 181 CPP.

Propuestas

Ante las problemáticas y falencias que han sido analizadas en esta investigación, se plantean propuestas, para que un día, muy pronto, sean tenidas en cuenta por quienes administran justicia para un pueblo libre dentro de un Estado social de derecho y democrático.

En las facultades de Derecho veo dos aspectos a solucionar: el primero, que los decanos de las facultades de Derecho o quienes hagan sus veces, tengan una formación y un perfil con conocimiento suficiente en la proyección de la realidad social, en el marco de nuestra cultura jurídica, así como una formación en docencia, con proyección hacia ser líderes académicos, con visión jurídica, conocimiento social y solución de las problemáticas, especialmente en el área penal.

El segundo, que los programas de Derecho, tengan una asignatura en la cual se conozcan y estudien las diversas culturas jurídicas enfocadas en el tema de la discrecionalidad judicial. Importante que se implante una práctica de orientación jurídico-social, donde los alumnos tengan la oportunidad de observar el rol del juez en el desarrollo del 
conocimiento de la ley, la aplicación de la jurisprudencia y analizar el contenido de las decisiones judiciales, es decir adquirir habilidades y competencias para en un futuro desarrollar la función de juez. La misma preparación y orientación que se da en los consultorios jurídicos, para desempeñar la función de abogado defensor, debe ser impartida de igual forma, para desarrollar en un futuro la función de juez de la República. En tercer lugar, propongo que la escogencia de los jueces en el campo penal, ya sean jueces, magistrados y demás, se realice con la exigencia de un perfil, a través de pruebas psico-técnicas, además del examen de conocimiento, que conduzcan a establecer que este futuro funcionario judicial cuenta con las habilidades de personalidad necesarias para desarrollar la delicada labor de tomar decisiones judiciales.

Se propone que a través de un Acto Legislativo se pueda definir con claridad qué decisiones judiciales resultan vinculantes, si solamente las proferidas por la Corte Constitucional, por la sala penal de la Corte Suprema de Justicia, o por los Tribunales Superiores del Distrito Judicial y por decisiones similares de los jueces penales de conocimiento, pues muchas de las decisiones en el campo penal se toman de acuerdo al arbitrio de los jueces. 


\title{
Anexo 1: Respuesta Derecho de Petición de Información EXPSA14-4789
}

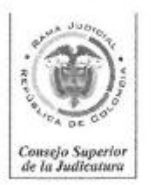

\author{
Rama Judicial del Poder Público \\ Consejo Superior de la Judicatura \\ Sala Administrativa \\ Dirección Ejecutiva de Administración Judicial
}

ANEXO 1

DEAJPL14-1270

Bogotá D.C., martes, 28 de octubre de 2014

Señor

GERMAN ALONSO CASTAÑEDA TORRES

Carrera 2 E No. 3-32 casa 123 Conjunto Residencial "Huertas de Cajicá 2"

Cel. 3105608425

Cajicá-Cundinamarca

Asunto: "Derecho de Petición de Información. EXPSA14-4789"

Apreciado Señor CASTAÑEDA:

De manera atenta me permito dar respuesta al punto No. 1 de su solicitud, relacionado con "Cuál fue el presupuesto asignado a la Rama judicial para su funcionamiento en el año 2013 y cuál es asignado para la vigencia 2014

PRESUPUESTO ASIGNADO RAMA JUDICIAL

\begin{tabular}{|l|r|r|}
\hline \multicolumn{1}{|c|}{ TOTAL PRESUPUESTO } & \multicolumn{2}{|c|}{2014} \\
\hline Gastos de Personal & 2.249 .661 & \multicolumn{1}{c|}{2013} \\
\hline Gastos Generales & 222.997 & 2.241 .196 \\
\hline Transferencias & 48.572 & 215.150 \\
\hline Subtotal Funcionamiento & $\mathbf{2 . 5 2 1 . 2 3 0}$ & 44.099 \\
\hline Inversion & 342.000 & $\mathbf{2 . 5 0 0 . 4 4 6}$ \\
\hline Total & $\mathbf{2 . 8 6 3 . 2 3 0}$ & 331.910 \\
\hline
\end{tabular}

La Sala Administrativa ha dado traslado de su oficio a la Unidad de Desarrollo y Análisis Estadistico dada la especificidad del asunto con el cual se relaciona la información solicitada. .

Cordial Saludo.

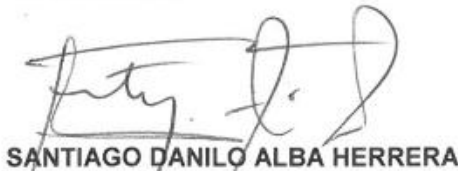

SANTIAGO DANILO ALBA H

D
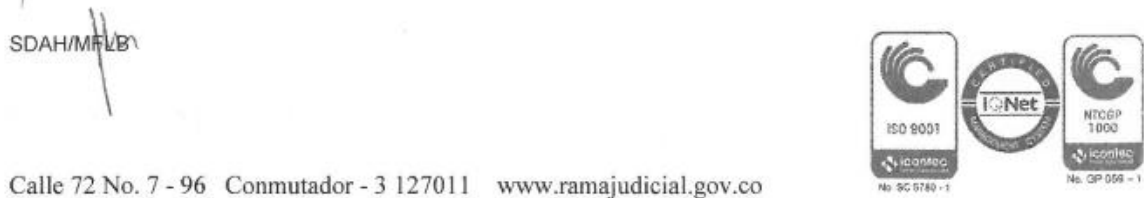

Calle 72 No. 7 - 96 Conmutador-3127011 www.ramajudicial.gov.co 


\section{Anexo 2: Respuesta a solicitud de información sobre despachos del SPA}

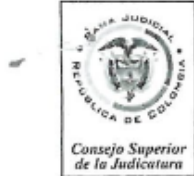

Rama Judicial del Poder Público Consejo Superior de la Judicatura

$$
\text { Sala Administrativa }
$$

Unidad de Desarrollo y Análisis Estadístico

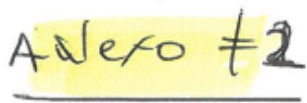

UDAEOF14-2824

Bogotá, D. C., martes, 09 de diciembre de 2014

Señor

GERMAN ALONSO CASTAÑEDA TORRES

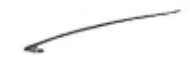

Estudiante Maestría

Carrera $2^{\mathrm{a}} \mathrm{E}$ No. $3-32$ casa 123

Conjunto Residencial "Huertas de Cajicá 2"

Cundinamarca

Asunto: "Respuesta a solicitud de información sobre despachos del SPA."

Apreciado señor Castañeda:

En respuesta a la solicitud realizada por el oficio en mención, y por el radicado PSA14 4355, relacionado con Ley 906 de 2004 que implementó el Sistema Penal Acusatorio (SPA), de manera atenta me permito dar respuesta a los literales 2 y 3 como se presenta a continuación:

2. De acuerdo con la estructura de la Rama Judicial del poder público y el mapa judicial Colombiano, cuál es el número de:

Al respecto me permito informar que a nivel nacional se encuentran distribuidos los funcionarios con las siguientes especialidades consultadas:

a) Jueces penales municipales: $\mathbf{4 9 1}$

b) Penales del circuito: $\mathbf{3 4 7}$

c) Penales del circuito especializado: 66

d) Número de magistrados de los Tribunales Superiores de Distrito Judicial y su distribución por Distritos (Ver anexo de este oficio)

3. De acuerdo con los estudios y diagnósticos que se han realizado, cuál es el número de jueces penales que se requieren a Nivel Nacional para que haya una justicia eficaz y eficiente.

Al respecto de manera atenta me permito poner en contexto que el número de jueces penales que se requieren para la eficacia y eficiencia de la justicia en el Colombia, de acuerdo con los diferentes estudios y análisis que se desarrolian constantemente, actualmente se cuentan con el número necesario de juzgados los cuales actualmente cubren las necesidades de demanda de justicia en todo el territorio nacional, pues cada municipio del país cuenta con un despacho judicial en el cual pueden radicar los procesos penales. La eficacia y eficiencia de la justicia en el país no se pude medir únicamente por el número de juzgados con el que se cuente, dado que en el trascurso

Calle 12 No. 7 - 65 Conmutador - 2841945 www.ramajudicial.gov.co

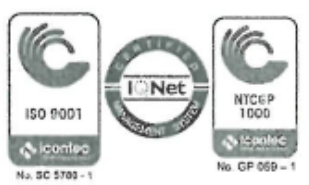


Hoja No. 2

que debe surtir un proceso antes de ser presentado ante los jueces de la república, intervienen varios actores que son directamente vinculantes, tanto gubernamentales como particulares, que tiene relación directa con todo proceso.

Adicionalmente, el número de juzgados a crear en un futuro inmediato es directamente proporcional con el número de procesos nuevos que se radiquen ante los jueces penales de la república, los cuáles son radicados directamente por el ente acusador del país, función que recae directamente en la Fiscalia General de la Nación, por ende para que esta Corporación pueda determinar el número de juzgados penales que se puedan llegar a requerir se debe contar con la información del número de procesos que la Fiscalia va a radicar ente la justicia penal.

Cordialmente,

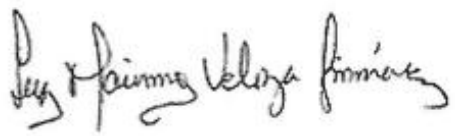

LUZ MARINA VELOZA JIMÉNEZ

Directora

CMHG/NNBR/LMVR/CLMB - EXPSA14-4789 y PSA14-4355

Calle 12 No. 7 - 65 Conmutador - 2841945 www.ramajudicial.gov.co 


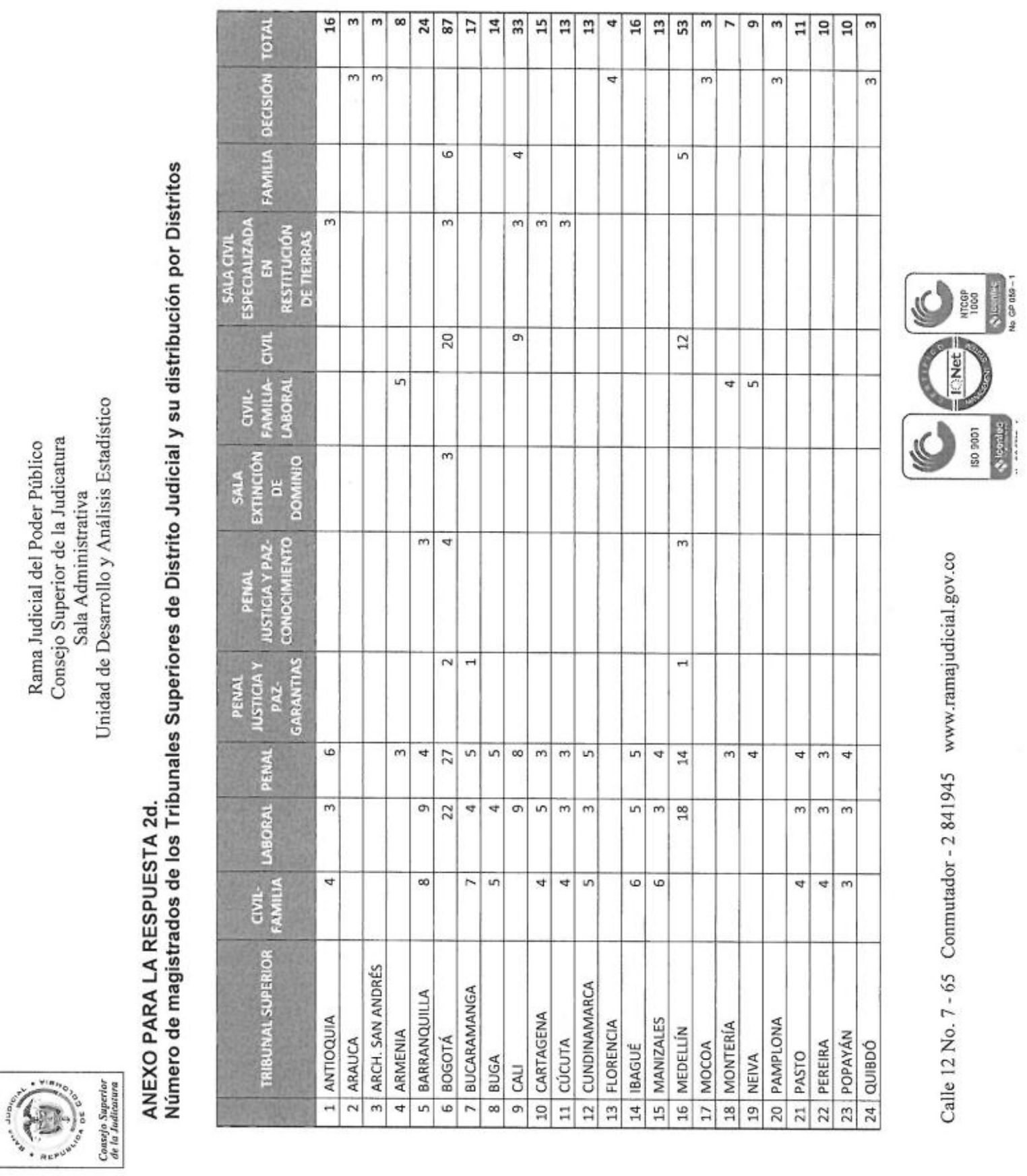




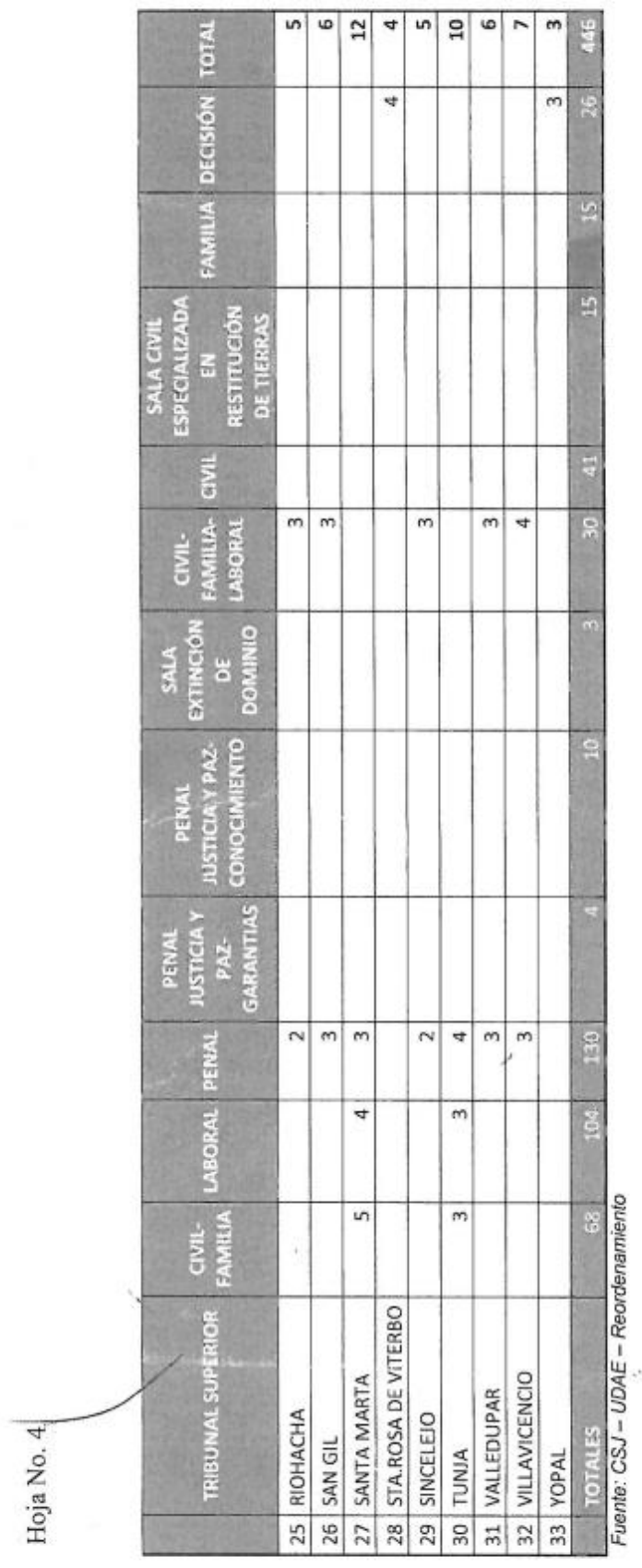

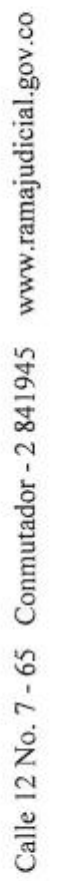




\title{
Anexo 3: Derecho de Petición de Información EXPSA14-4789
}

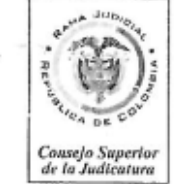

\author{
Rama Judicial del Poder Público \\ Consejo Superior de la Judicatura \\ Sala Administrativa \\ Unidad de Desarrollo y Análisis Estadístico
}

ANEXO 3

UDAEOF14-2908

Bogotá, D. C., jueves, 18 de diciembre de 2014

Señor

GERMAN ALONSO CASTAÑEDA TORRES

Estudiante Maestria

Carrera $2^{\mathrm{a}}$ E No. 3-32 casa 123

Conjunto Residencial "Huertas de Cajicá 2"

Cajicá - Cundinamarca

Asunto: "Remito respuesta de la escuela judicial"

Apreciado señor Castañeda:

De manera atenta me permito remitir copia de la respuesta por parte de la Escuela Judicial a los puntos de su derecho de petición solicitados a esta entidad, frente al tema de capacitación y formación.

Se anexan dos hojas.

Cordialmente,

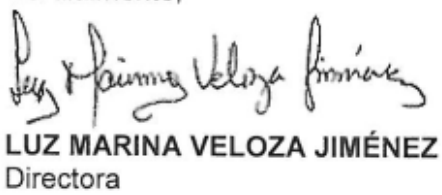

CMHG/NNBR - EXPSA14-4789

ANEXO

Calle 12 No. 7 - 65 Conmutador - 2841945 www.ramajudicial.gov.co

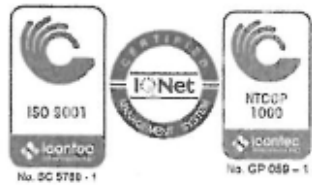


Hoja No. 2

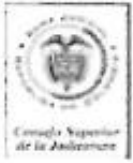

\author{
R.mana Judicial del Poder Publico \\ Consejo Superior de la Judicanara \\ Saia Adainistrativa \\ Escuela Judicial "Rodrigo Lara Bonillx"
}

EJOF $14-3408$

Bogotá, D.C., viemes, 31 de octubre de 2014

Doctor

PEDRO OCTAVIO MUNAR CADENA

Presidente Sala Aoministrativa

Consejo Superior de la Judicatura

Ciudad

Asunto: Derecho de petición EXPSA14-4789.

Comedidamente me permito remitir para su consideración las respuestas que estimo pertinentes al numeral 6 del Derecho de Petición que formuló el ciudadano German Alonso Castañeda Torres.

- La Sala Administrativa del Consejo Superior de la Judicatura a través de la Escueia "Judicial Rodrigo Lara Bonilla" como centro de formación inicial y continuada de los funcionanos y empleados al servicio de la administración de justicia, para capacitar a los servidoredas judiciales vinculados al Sisterna Penal Acusatorio ha cesarrollado las siguientes actividades acadénicas:

- Conversatorios Intemacionales

- Conversatorios Nacionales

- Conversatorios Zonales

- Cursos de Implementación del Sistema Penal Acueatorio

- Cursos de incorporación al Sistema Penal Acusatorio

- Cursos de Profundización

- Pasantias a nivel intemo y extemo

- Simulación de oudiencia

En el desarrollo de los eventos académicos enunciados, se ha impartido temática transversal como Argumentación Judicial, Argumentación en Decisiones Judiciaies, Argumentación en Audiencias Preliminares, Filosofia Del Derecho, Género y Justicia, Ética Judicial, Interpretación Judicial y Constitucional, Juez Director del Despacho, Juez Director del Proceso y Estructura de la Sentencia.

En formación especializada se ha trabajado entre otras la siguiente temática: Bloque de Constitucionalidad, Control de Garantias, Manual para el Juez de Control de Garantias, Sistema Probatorio del Juicio Oral, Técnicas de Oralidad, Control Judicial a las Negociaciones Preacordadas, Principio de Oportunidad Preacuerdos y Negociaciones, Audiencias del Juicio Orai, Manejo e Incorporación

Calle 12 No. 9A-24 Tel: 3364025 - 3410147 - 3410758 sพvwramxjudicial, gov.co

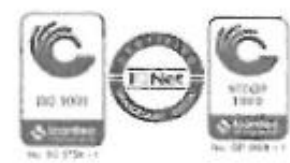

Calle 12 No. 7 - 65 Conmutador-2 841945 www.ramajudicial.gov.co 
* * Hoja No. 3

Hoja No. 2

de Evidencias, Dirección de la Audiencias desde la Argumentación Judicial, Control Material al Escrito de Acusación, etc.

- La Sala Administrativa a través de la Escuela Judicia, ha capacitado a 1143 juecee/zas y magistrados/as, la gran mayoria de ellos han recibido varios cursos de formación judiciol e incluso el curso concurso para el ingreso a la carrera.

- El presupuesto asignado para la capacitación de los servidores y servidoras judiciales es el siguiente:

- Para la vigencia fiscal 2013: ochocientos cinco millones setecientos veintidós mi quinientos treinta y ocho pesos $\$ 805.722 .538 .00$

- Para la vigencia Fiscal 2014: mil noventa y tres miliones cuatrocientos sesenta y un mil cuatrocientos setenta y siete pesos $\$ 1.093 .461 .477 .00$

- Respecto del diagnóstico de necesidedes de formación judicial en el Sistema Acusatorio Penal, es que se hace necesario realizar una capacitación intensiva sobre la Argumentación en Audiencias Preliminares, Audiencias del Juicio Oral Manejo e incorporación de evidencia y Penal Especial, capacitación que se aprobó en el Plan de Formación de la Rama Judiciai de la presente vigencia fiscal y está en proceso ejecucion.

Corcialmente,

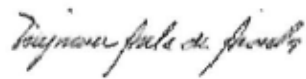

MYRIAM AVILA DE ARDILA

Directora

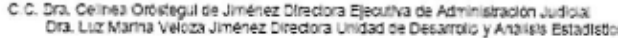

EJFLENANJJPG

Calle 11 No. 9A- 24 Tels: 3364025 - $3410147-3410758$

พพาพ ramsjudicial. gow:co

Calle 12 No. 7 - 65 Conmutador - 2841945 www.ramajudicial.gov.co 


\section{Bibliografía}

Alcinicof, A. (1996). Constitutional law in the age balancing. Yale law journal, 943.

Alexy, R. (2001). Teoría de la argumentación jurídica. Sao Pablo: Landy.

Benítez, V. F., \& González, G. A. (2009).Kennedy como pretor: Una crítica de los estudios críticos del derecho a la teoria de la adjudicación judicial y a las teorías jurídicas dominantes en Colombia. Bogotá: Univ. Estud.

Bernate, F. (2014). El sistema penal del Common Law. Bogotá: Grupo Editoria Ibañez.

Bonorino, P. R., \& Peña, J. I. (2006). Filosofía del derecho (Segunda edición aumentada ed.). Bogotá: Escuela Judicial Rodrigo Lara Bonilla.

Botero Uribe, D. (2004). Teoría Social del Derecho. Bogotá: Universidad Nacional de Colombia.

Brinks, D. (2005). Judicial Reform and Independence in Brazil and Argentina: The Beginning of the New Millenium.

Bustamante, T. (Junio de 2006). La interpretación constitucional. Universitas Estudiantes de la Pontificia Universidad Javeriana(3), 149.

Código de Procedimiento Penal. (2004). Ley 906. Bogotá: Legis.

Consejo Superior de la Judicatura. (2005). Acuerdos y Preacuerdos. Bogotá: Sala Administrativa.

Constitución Política de Colombia. (1991). Bogotá: Legis.

Contreras, J. A. (2011). El precedente judicial en Colombia: Un análisis desde la teoría del derecho. Revista Facultad de Derecho y Ciencias Politicas, 41(115), 331-361.

Consejo Superior de la Judicatura. (2005). El rol de los jueces y magistrados en el sistema penal acusatorio colombiano. Bogotá: Chechi and Company Consulting Colombia.

Cotes, C. P., \& Fuentes, A. (2012). Populismo punitivo: incidencia actual en el contexto legislativo colombiano. Actualidad Jurídica, 64-70. 
Courtis, C. (2009). Ecos cercanos. Escritos sobre derechos humanos y justicia. Bogotá: Siglo del Hombre Editores.

Cuadernos de derecho penal. No. 11. (2014). Proceso penal y dogmática. Bogotá: Universidad Sergio Arboleda.

Cuadernos de derecho penal. No. 12. (2014). Derecho penal y crisis de la dogmática. Bogotá: Universidad Sergio Arboleda.

David, R. (1956). L_originalité des Drotis del Amerique Latine. Paris: Université de Paris.

Defensoría Del Pueblo. (2013). Reflexiones de derecho penal y procesal penal. Bogotá: Imprenta Nacional de Colombia.

Doxa. (1988). Entrevista con Herbert L. A. Hart. Buenos Aires: Juan Ramón de Páramo.

Dworkin, R. (1984). Los derechos en serio. Barcelona: Ariel.

Esquirol, J. (2014). Las Ficciones del Derecho Latinoamericano. Bogotá: Siglo del Hombre Editores.

Fernandez Carrasquilla, J. (1992). La solución penal de los conflictos sociales. En J. Fernandez Carrasquilla, Concepto y límites del derecho penal (pág. 64). Bogotá: Temis.

Garapon, A., \& Papadopoulos, I. (2010). Juzgar en Estados Unidos y en Francia. Bogotá: Legis.

García Amado, J. A. (julio-diciembre de 2006). ¿Existe discrecionalidad en la decisión judicial? Isegoría(35), 151-172.

Garcia Amado, J. A. (2008). Jornadas Internacionales de Derecho Penal y Filosofía del Derecho. Medellín: Universidad EAFIT.

Gómez, J. L. (2012). El Proceso Penal Adversarial. Una crítica constructiva sobre el llamado sitema acusatorio. México: Ubijus.

Grosso, M. S. (2005). ¿Justicia material o eficientismo punitivista? Las dos caras de la reforma al sistema penal colombiano. Revista JUSTA, 13-43.

Guthmann Y. (2012). La decisión judicial y lo político. Una mirada socio-legal. Revista electrónica del Instituto de Investigaciones Ambrosio L. Gioja, 6 (9), 80 - 101.

Hart, H. L. (1998). El concepto de derecho. Buenos Aires: Abeledo-Perrot. 
Hassemer, W. (2003). Critica al derecho penal de hoy. Buenos Aires: Ad-hoc Editores.

Herget, J., \& Wallace, S. (1987). The German Free Law Movement as the Source of American Legal Relism. Va. L. Rev, 73(399).

Instituto Nacional Penitenciario, INPEC. (2013). Informe Estadístico. Bogotá.

Karst, K., \& Rosenn, K. (1975). Law and Development in Latin America. California: University or California Press.

Kelsen, H. (1934). Teoría pura del derecho. Buenos Aires: Eudeba.

Kennedy, D. (1999). Libertad y restricción en la decisión judicial. Bogotá: Siglo del Hombre Editores.

Kennedy, D. (2000). La educación legal como preparación para la jerarquía. Buenos Aires: Desde otra mirada.

López, D. (2006). El derecho de los jueces. Bogotá: Legis.

López, D. (2006). El proceso penal entre la eficiencia y la justicia. Bogotá: Consejo superior de la judicatura.

López, D. (2006). Interpretación Constitucional. Bogotá: Unibiblos .

Molina, R. (2012). La conformidad en el proceso penal. Bogotá: Grupo editorial Ibáñez.

Nanclares, A. (2012). Los Jueces de Mármol. Bogotá: Grupo editorial Ibáñez.

Prieto, L. (2003). Justicia constitucional y derechos fundamentales. Madrid: Trotta.

Ruiz Manero, J., \& Schmill, U. (2008). El juez y las lagunas del derecho. México: Distribuciones Fontamara S.A.

Tamayo Jaramillo, J. (2011). La decisión judicial. Bogotá: Legis.

Torres, N. (2010). Populismo punitivo en Colombia: una aproximación a la política legislativa de las recientes reformas de los delitos sexuales. Medellín: Escuela de Derecho Universidad EAFIT.

Uprimny, R. (2006). Reflexiones sobre el nuevo sistema procesal penal. No. 2. Bogotá: Procuraduría General de la Nación.

Uprimny, R., \& García Villegas, M. (2003). Corte Constitucional y Emancipación Social en Colombia. Bogotá. 
Von Ihering, R. (1990). El cielo de los conceptos jurídicos: una fantasía. En R. Von Ihering, Bromas y veras en la jurisprudencia, la lucha por el derecho. Bogotá: Temis.

Wolkmer, A. C. (2003). Introducción al pensamiento jurídico crítico. Bogotá: ILSA Ediciones. 